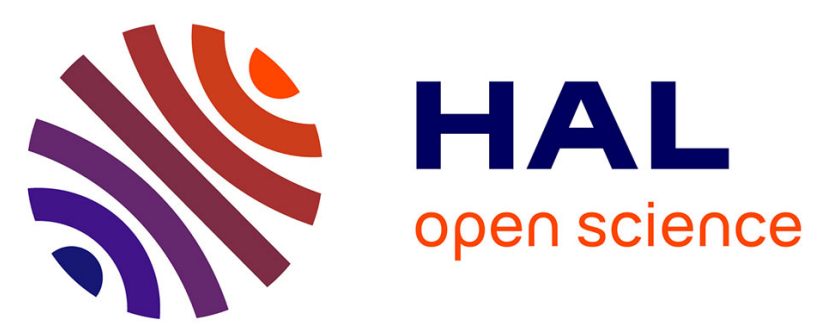

\title{
Crustal structure and magmato-tectonic processes in an active rift (Asal-Ghoubbet, Afar, East Africa): 2. Insights from the 23-year recording of seismicity since the last rifting event
}

\author{
C. Doubre, Isabelle Manighetti, C. Dorbath, L. Dorbath, D. Bertil, J. C. \\ Delmond
}

\section{To cite this version:}

C. Doubre, Isabelle Manighetti, C. Dorbath, L. Dorbath, D. Bertil, et al.. Crustal structure and magmato-tectonic processes in an active rift (Asal-Ghoubbet, Afar, East Africa): 2. Insights from the 23-year recording of seismicity since the last rifting event. Journal of Geophysical Research: Solid Earth, 2007, 112 (B5), pp.B05406. 10.1029/2006JB004333 . insu-00198815

\section{HAL Id: insu-00198815 https://hal-insu.archives-ouvertes.fr/insu-00198815}

Submitted on 30 Jul 2020

HAL is a multi-disciplinary open access archive for the deposit and dissemination of scientific research documents, whether they are published or not. The documents may come from teaching and research institutions in France or abroad, or from public or private research centers.
L'archive ouverte pluridisciplinaire HAL, est destinée au dépôt et à la diffusion de documents scientifiques de niveau recherche, publiés ou non, émanant des établissements d'enseignement et de recherche français ou étrangers, des laboratoires publics ou privés. 


\title{
Crustal structure and magmato-tectonic processes in an active rift (Asal-Ghoubbet, Afar, East Africa):
}

\section{Insights from the 23-year recording of seismicity since the last rifting event}

\author{
C. Doubre, ${ }^{1,2,3}$ I. Manighetti, ${ }^{1,4}$ L. Dorbath, ${ }^{5,6}$ C. Dorbath,,${ }^{5,6}$ D. Bertil, ${ }^{7,8}$ \\ and J. C. Delmond ${ }^{7}$
}

Received 6 February 2006; revised 30 October 2006; accepted 6 March 2007; published 10 May 2007.

[1] The Asal-Ghoubbet (AG) Rift has sustained a major volcano-tectonic rifting episode in 1978 and has been subsequently monitored with continuous geodetic and seismological surveys. It is therefore an ideal place to study the transient magmato-tectonic processes that operate after a rifting episode. We examine the space-time evolution of $\sim 2500 \mathrm{Md} \leq 2.8$ earthquakes recorded in the rift from 1979 to 2001 . We focus on the relationships between this seismic activity and both the three-dimensional structure of the rift and its postrifting behavior depicted from geodesy. The results highlight the major role of the central magmatic system (Fieale-Shark Bay) on the structure, seismic activity, and overall behavior of the rift. From 1978 to 1986, the rift opens at a fast rate, yet mainly aseismically; the opening is magmatically driven and accommodated. Since 1986, when the opening rate abruptly decreased, the seismicity is concentrated in the central part of the rift and reveals pulses of activity of the central volcanic system. These pulses result from that magmatic zone undergoing alternating stretching and inflating episodes. Thus, while the plate-driven induced stresses have been rebuilding in the rift since 1987, the rift opening is still essentially accommodated in the axial magmatic zone. The AG Rift has thus sustained a postrifting unsteady opening over more than 23 years following its stretching episode. That transient opening has essentially occurred aseismically, and most tectonic faults remain relaxed and locked.

Citation: Doubre, C., I. Manighetti, L. Dorbath, C. Dorbath, D. Bertil, and J. C. Delmond (2007), Crustal structure and magmatotectonic processes in an active rift (Asal-Ghoubbet, Afar, East Africa): 2. Insights from the 23-year recording of seismicity since the last rifting event, J. Geophys. Res., 112, B05406, doi:10.1029/2006JB004333.

\section{Introduction}

[2] The increasing use and improvement of space geodetic measurements in the last 20 years show that plate motions occur at constant rates similar to those deduced on geological timescales, provided that these rates are measured from plate interiors [e.g., DeMets et al., 1990;

\footnotetext{
${ }^{1}$ Laboratoire de Tectonique, Institut de Physique du Globe de Paris, Paris, France.

${ }^{2}$ Laboratoire de Géodynamique des Rifts et des Marges Passives, Université du Maine, Le Mans, France.

${ }^{3}$ Now at Department of Earth and Space Sciences, University of California, Los Angeles, California, USA.

${ }^{4}$ Now at Laboratoire de Géophysique Interne et Tectonophysique, Grenoble, France.

${ }^{5}$ Ecole et Observatoire des Sciences de la Terre, Strasbourg, France.

${ }^{6}$ Institut de Recherche pour le Développement, Paris, France.

${ }^{7}$ Volcanologic Observatories, Institut de Physique du Globe de Paris, Paris, France.

${ }^{8}$ Now at Bureau de Recherches Géologiques et Minières, Service Géologique Régional Guadeloupe, Guadeloupe, France.
}

Copyright 2007 by the American Geophysical Union. 0148-0227/07/2006JB004333\$09.00
McClusky et al., 2000; Beavan et al., 2002; Kreemer et al., 2003]. In contrast, relative motions of plates are highly episodic at their boundaries. While earthquakes are responsible for most of these episodic motions, an increasing amount of evidences shows that most plate boundaries additionally sustain transient deformation episodes. Those generally result from the postseismic relaxation response of the crust and lithosphere [e.g., Savage et al., 1998; Pollitz et al., 2000; Hu et al., 2004]. In other cases, however, transient deformation occurs with no clear link with earthquakes. This is the case for the "silent or slow earthquakes", which are found along convergent and possibly transform plate boundaries [e.g., Okal and Stewart, 1982; Linde et al., 1996; Hirose et al., 1999; Lowry et al., 2001; Melbourne et al., 2002; Miller et al., 2002]. Because these slow aseismic earthquakes accommodate as much deformation as the "classical" seismic ruptures, full comprehension of the Earth's plate system cannot be made without a better understanding of the transient deformation episodes that may affect the plate boundaries. Among other questions, we still must answer the following: Where, when, and why transient deformation episodes do occur on a given plate 


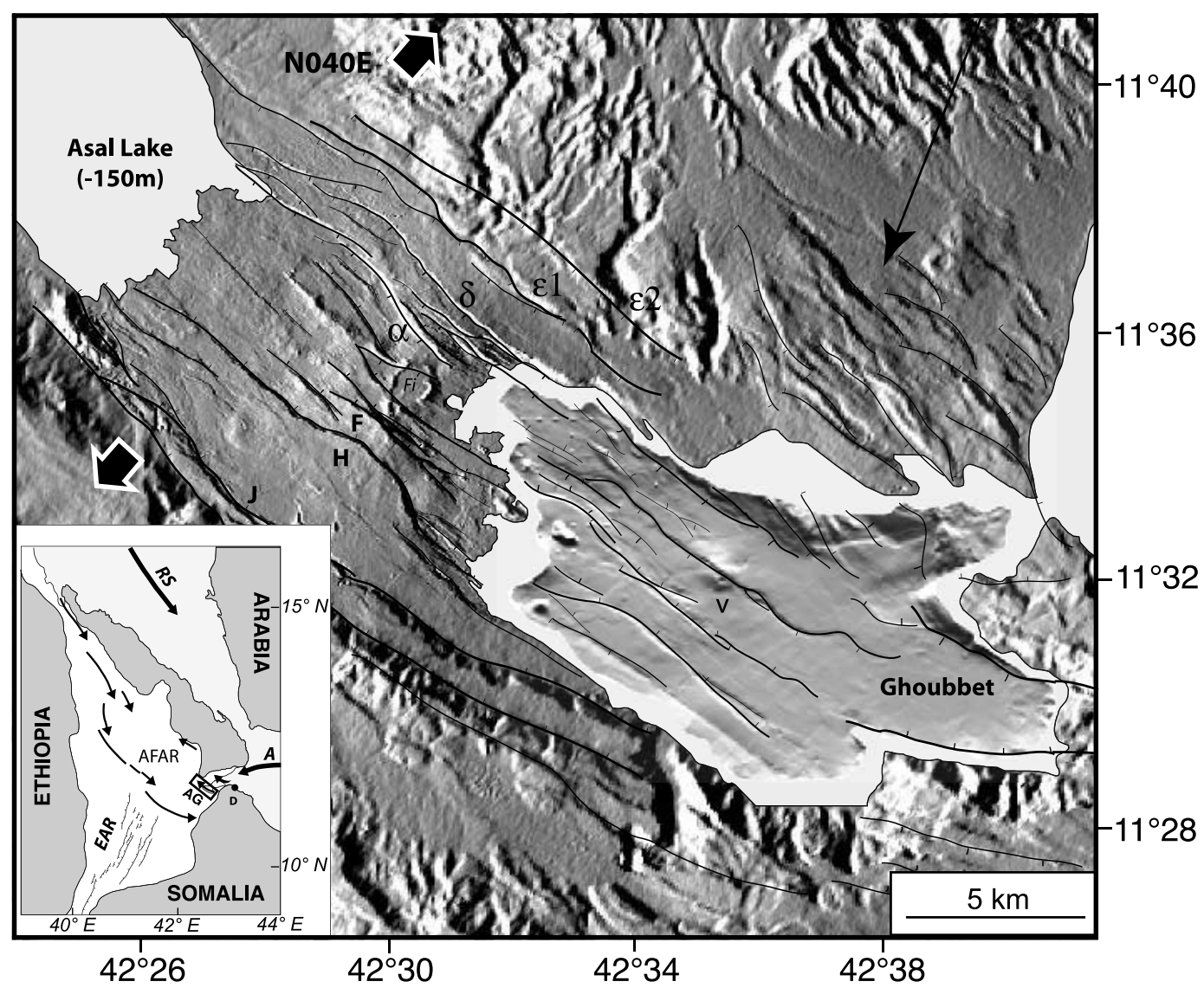

Figure 1a. Topographic and tectonic map of Asal-Ghoubbet Rift. Faults $(\alpha, \delta, \varepsilon, \mathrm{F}, \mathrm{H}, \mathrm{J}, \mathrm{K})$ are redrawn from Manighetti et al. [2001a, 2001b] and Audin et al. [2001]. Fi, Fieale caldera; v, easternmost recent volcano in Ghoubbet; AG-T, Asal-Ghoubbet/Tadjoura transfer faults. Inset shows the general setting of Afar Depression, at junction between East African Rift (EAR), Red Sea Ridge (RS), and Aden Ridge (A). D, Djibouti. Arrows are propagating, active rift segments (see Manighetti et al. [2001a] for more details). Asal-Ghoubbet Rift (AG) is indicated by a rectangle.

boundary? How are these transient episodes related to major earthquakes or seismic crises on these boundaries? How much strain does the transient deformation accommodate? How do the transient deformation episodes evolve from the plate boundaries to steady deformation within the plate interior?

[3] We address some of these questions for divergent plate boundaries, where the motions are highly episodic [e.g., Björnsson, 1985; Heki et al., 1993]. We focus on the Asal-Ghoubbet Rift (AG, East Africa) which belongs to the oceanic Aden Ridge propagating into the Afar Depression (inset, Figure 1a). The AG Rift is one of the very rare active rift segments worldwide that extends onto land [e.g., Varet, 1978; Tapponnier et al., 1990; Manighetti et al., 1998]. This makes the AG Rift an exceptional field laboratory where direct observations and measurements can be performed.

[4] In November 1978, the rift sustained a major volcanotectonic rifting episode. The deformation associated with this rifting episode corresponds to $\sim 2 \mathrm{~m}$ of horizontal opening and up to $70 \mathrm{~cm}$ of vertical displacements [Ruegg et al., 1979]. Since this episode, the regular geodetic survey reveals significant variations of the vertical and horizontal motion rates in the rift [Ruegg and Kasser, 1987; Ruegg et al., 1987; Kasser et al., 1987; Cattin et al., 2005]. This suggests that during the postrifting period, the rift behavior is still unsteady, i.e., dominated by transient deformation. A geophysical observatory has existed in Djibouti since 1972 (operated by CERD Djibouti and IPGP France). The observatory has established and maintained a permanent seismological network in the AG Rift which has allowed the recording of $\sim 2500$ microearthquakes during the 23 years following the 1978 rifting episode (1979-2001). This data set provides a unique opportunity to analyze the postrifting behavior of the AG segment and specifically address the following questions: Is the post-1978 opening of the rift a seismic or an aseismic process? What and where are the structures and/or processes responsible for the recorded seismicity and for the rifting process in general? What are the respective contributions of tectonic and magmatic activities and their interactions to that seismic activity? Is this seismicity related to measured deformations? Does the time evolution of the seismicity reveal an evolution of the tectonic and magmatic activities or a postopening relaxation process? What does the recorded seismicity reveal on the 
three-dimensional (3-D) thermomechanical structure of the AG Rift?

[5] The present paper is the second of a series of two [Doubre et al., 2007]. While they can be read independently, together they combine to address the previous questions at two complementary timescales. The first paper describes the results of a 5-month seismological experiment that we conducted in the rift during the winter 2000-2001. The density and accuracy of the located microevents allowed the examination of the rift 3-D crustal structure, and some active structures/processes to be identified. We found that the rift structure is dominated by a central magmatic plumbing system, Fieale-Shark Bay (Fieale-SB), which plays a dominant role in the current seismic activity of the rift. The 23-year earthquake data set that we analyze here allows discussing further the 3-D crustal structure of the rift and the nature/distribution of the features responsible for its seismic activity. Comparing our results with the available geodetic measurements further allows describing the overall rift behavior since its last rifting episode. This shows that the Fieale-Shark Bay plumbing system has been governing the rift behavior over the whole postrifting period, and that the rift is still in a transient stage. Our study thus sheds light on the transient magmato-tectonic mechanisms that contribute to the rifting cycle, hence to the overall behavior of divergent plate boundaries.

[6] Note that while the geodetic measurements in AG have been presented in a number of previous papers [Ruegg et al., 1979, 1987, 1990; Ruegg and Kasser, 1987; Tarantola et al., 1979, 1980; Vigny et al., 2006a], no attempt has ever been made to analyze the complete set of seismological data recorded up today in the Asal-Ghoubbet Rift (only short data subsets have been published so far [see Abdallah et al., 1979; Lépine et al., 1980; Lépine and Hirn, 1992]). The objective of the present paper is also to fill that gap.

\section{Geological Setting}

[7] The Afar depression, East Africa, is the only place in the world where a continental plate (Arabia-Africa) is presently breaking apart such that a new ocean is currently being formed (Figure 1a, inset). The plate started to break $\sim 30 \mathrm{Ma}$ ago when a mantle plume impinged its lithosphere [e.g., Courtillot et al., 1999]. Subsequently, the plate has been breaking apart along three large-scale rift/ridge zones: the intracontinental East African Rift and the oceanic ridges of the Red Sea and the Gulf of Aden (Figure 1a, inset). Breaking is not yet complete, however, as the two plate pieces are still "attached" in the active rifting Afar region, with no oceanic spreading between the Gulf of Aden and the Red Sea [Courtillot et al., 1987; Tapponnier et al., 1990; Manighetti et al., 1997]. Several disconnected rift segments are currently stretching the crust and lithosphere in Afar (Figure 1a, inset) [Tapponnier et al., 1990; Manighetti et al., 1997, 1998, 2001a; Hayward and Ebinger, 1996]. All are narrow, NW striking zones of localized active faulting, diking and volcanism, in which earthquakes and volcanic eruptions are common, as the rifting episode along the Dabbahu segment witnesses in September/October 2005 [Wright et al., 2006].

[8] The Asal-Ghoubbet segment (AG) is one of the youngest of these rifts ( $<1 \mathrm{Ma})$ [Varet, 1978; Courtillot,
1982; Manighetti et al., 1998] (Figure 1a). It has been opening at $15 \pm 2 \mathrm{~mm} / \mathrm{yr}$ along a $\sim \mathrm{N} 40 \pm 5^{\circ} \mathrm{E}$ direction [De Chabalier and Avouac, 1994; Manighetti et al., 1998; Vigny et al., 2006a, 2007]. It is a $\sim 40-\mathrm{km}-\mathrm{long}, \sim 15-\mathrm{km}-$ wide, NW striking graben shaped by a dense network of $\mathrm{N} 130 \pm 10^{\circ}$ striking normal faults running from the Asal Lake to the west to the easternmost part of the Ghoubbet basin to the east. Only the $\sim 15-\mathrm{km}$-long section of the rift between the two basins is on land (Figure 1b). In this section, the rift is bounded by a dozen steep $\left(70-80^{\circ}\right.$ at surface), inward dipping, major normal fault scarps, some as high as $200 \mathrm{~m}$. The innermost faults ( $\alpha$ and F-H) bound the rift inner floor, which is several hundred meters deeper than the highest sections of the rift shoulders. A dense network of open fissures roughly parallel to the faults dissects this inner floor. Detailed analyses of faulting have revealed that most rift faults, including those in the Ghoubbet, are young $(<80 \mathrm{ka})$ and have been active in recent times $(<10 \mathrm{ka}[$ Stein et al., 1991; Manighetti et al., 1998, 2001b; Audin et al., 2001]). Geodetic measurements further show that some faults are currently creeping at fast rates [several $\mathrm{mm} / \mathrm{yr}$; Ruegg and Kasser, 1987; Ruegg et al., 1990; Doubre and Peltzer, 2007; Vigny et al., 2006a, 2007] (auxiliary material ${ }^{1}$ Figure S1) similar to the long-term rates deduced from geological analyses [Stein et al., 1991, Manighetti et al., 1998; Audin et al., 2001]. ${ }^{1}$

[9] A large volcano, Fieale, occupies the eastern part of the subaerial inner floor, where a long-lived magma chamber is suspected [Allard et al., 1979; Demange et al., 1980; Joron et al., 1980, Van Ngoc et al., 1981]. That volcano has been active from $\sim 300$ to $80 \mathrm{ka}$ [Manighetti et al., 1998]. Its $\sim 1.5-\mathrm{km}$-wide, roughly circular caldera strongly imprints the topography. Two other volcanic features imprint the topography, the crater $\mathrm{f}$ and the Shark Bay caldera (SB, Figure 1b). The seismological analysis reported by Doubre et al. [2007] shows that the Fieale-Shark Bay volcanic complex is the major magmatic plumbing system of the rift. The shallowest part of this system $(<5 \mathrm{~km})$ includes a $\sim 2-\mathrm{km}$-wide pipe of heated rocks enclosed by an annulus of dense intrusions. The pipe is likely to rise above a deeper magma chamber, which, however, we could not image.

[10] Recent volcanism extends only within the rift inner floor, on either sides of the Fieale-Shark Bay system. To the northwest, it essentially spreads from a 5-km-long, NW trending axial volcanic chain (Figure 1b). To the southeast, recent volcanism has also produced broad lava fields originated from the small cones between faults $\mathrm{H}$ and $\mathrm{D}$, particularly the cone $f$ adjacent to Fieale (Figure 1b). The lava fields extend farther east on the western Ghoubbet floor, where several recent and partly submerged volcanoes and hyaloclastite edifices are observed (Figure 1a) [Audin et al., 2001].

[11] The AG Rift is $\sim 900$ ka old, but most structures older than $\sim 300$ ka have been buried under younger lava flows [Manighetti et al., 1998]. The long-term, 300-kalong evolution of the "modern" rift is marked by alternating phases of dominant magmatic activity, with large volumes

\footnotetext{
${ }^{1}$ Auxiliary materials are available in the HTML. doi:10.1029/ 2006JB004333.
} 


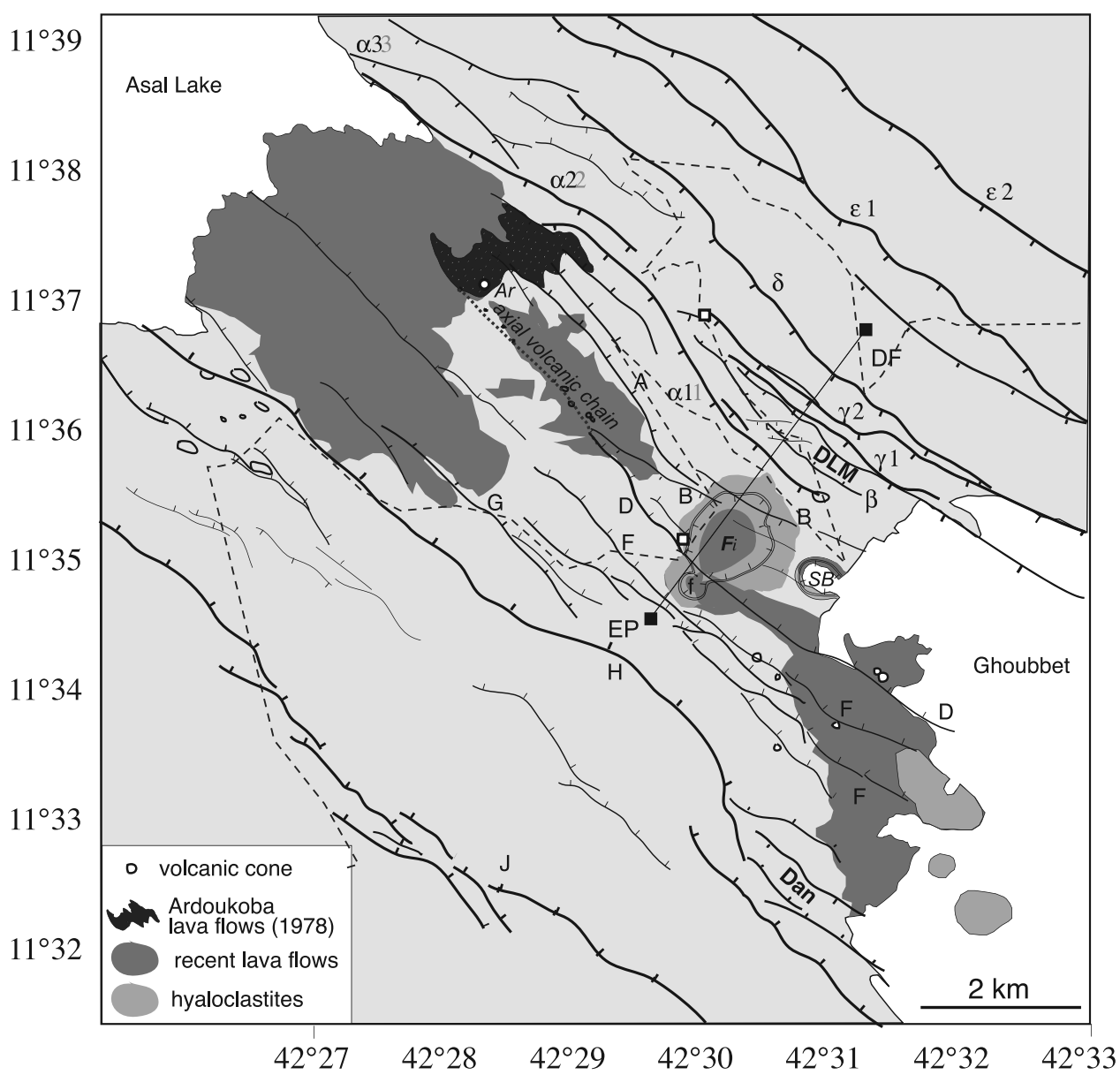

Figure 1b. Tectonic and geological map of subaerial section of AG Rift. Faults $(\alpha, \beta, \gamma, \delta, \varepsilon, \mathrm{A}, \mathrm{B}, \mathrm{D}$ F, G, H) are redrawn from Manighetti et al. [2001a, 2001b]. Fi, Fieale caldera; f, small caldera adjacent to Fieale; SB, Shark Bay caldera; Dan and DLM, Dankalelo and Disa Le Mallo subrifts, respectively [from Manighetti et al., 1998]. The dashed line shows the leveling profile discussed in text [Ruegg and Kasser, 1987; Vigny et al., 2007]. EP-DF is GPS profile of Figure S1a. The two open squares indicate leveling sites of Figure S1b and Figures S1c.

of basaltic lavas filling the inner floor and burying most previous faults, and phases of major faulting [Stein et al., 1991; Manighetti, 1993; De Chabalier and Avouac, 1994; Manighetti et al., 1998]. In the last $\sim 300 \mathrm{ka}$, volcanism evolved from fissural to central in the SE subaerial part of the rift where the Fieale-Shark Bay magma chamber is suspected [Allard et al., 1979; Demange et al., 1980; Joron et al., 1980, Van Ngoc et al., 1981]. In the last $\sim 100 \mathrm{ka}$, faulting has been dismantling the whole lava pile including the Fieale edifice [De Chabalier and Avouac, 1994], only interrupted by short phases of fissural volcanism. The locus of major faulting and stretching has migrated $\sim 30 \mathrm{ka}$ ago from south to north, jumping from the Dankalelo subrift to the Disa Le Mallo subrift (Figure 1b) [Manighetti et al., 1998]. Consequently, the northernmost faults (from $\alpha$ to $\delta$ ) are likely to be the youngest and most currently active, while the southern faults are expected to show little or no current activity.

[12] In November 1978, the AG Rift sustained a major rifting episode [Abdallah et al., 1979; Lépine et al., 1980]: Two large shocks occurred in the Ghoubbet $(\mathrm{mb}=5$ and 5.3) and were followed by 1-week-long basaltic fissural eruption at the northwestern tip of the volcanic chain, which gave birth to the Ardoukoba volcanic cone [e.g., Demange et al., 1980] (Figure 1b). The rift opened by $\sim 2 \mathrm{~m}$ along the $\sim \mathrm{N} 40^{\circ} \mathrm{E}$ direction, while its inner floor subsided by up to $70 \mathrm{~cm}$ [Ruegg et al., 1979]. Open fissures and normal fault scarplets appeared in the inner floor, while most of the inner and northern rift faults were reactivated [Le Dain et al., 1979]. Finally, the episode was followed by an aftershock sequence and an anomalously high seismic activity in the Ghoubbet and the Gulf of Tadjoura that lasted over 2 months [Lépine et al., 1980]. Mechanical modeling of the deformation suggests that the rifting episode resulted from the sudden opening of two 4- to 8-km-long dikes at 4-5 km depth in the rift inner floor, with the largest in the Ghoubbet [Tarantola et al., 1979, 1980].

[13] The geodetic measurements repeatedly performed in the rift since 1978 show that the rift went through two distinct major phases since its last rifting episode [Ruegg and Kasser, 1987; Cattin et al., 2005] (Figure S1a). During the immediate postrifting period from 1979 to $1986-1987$, 

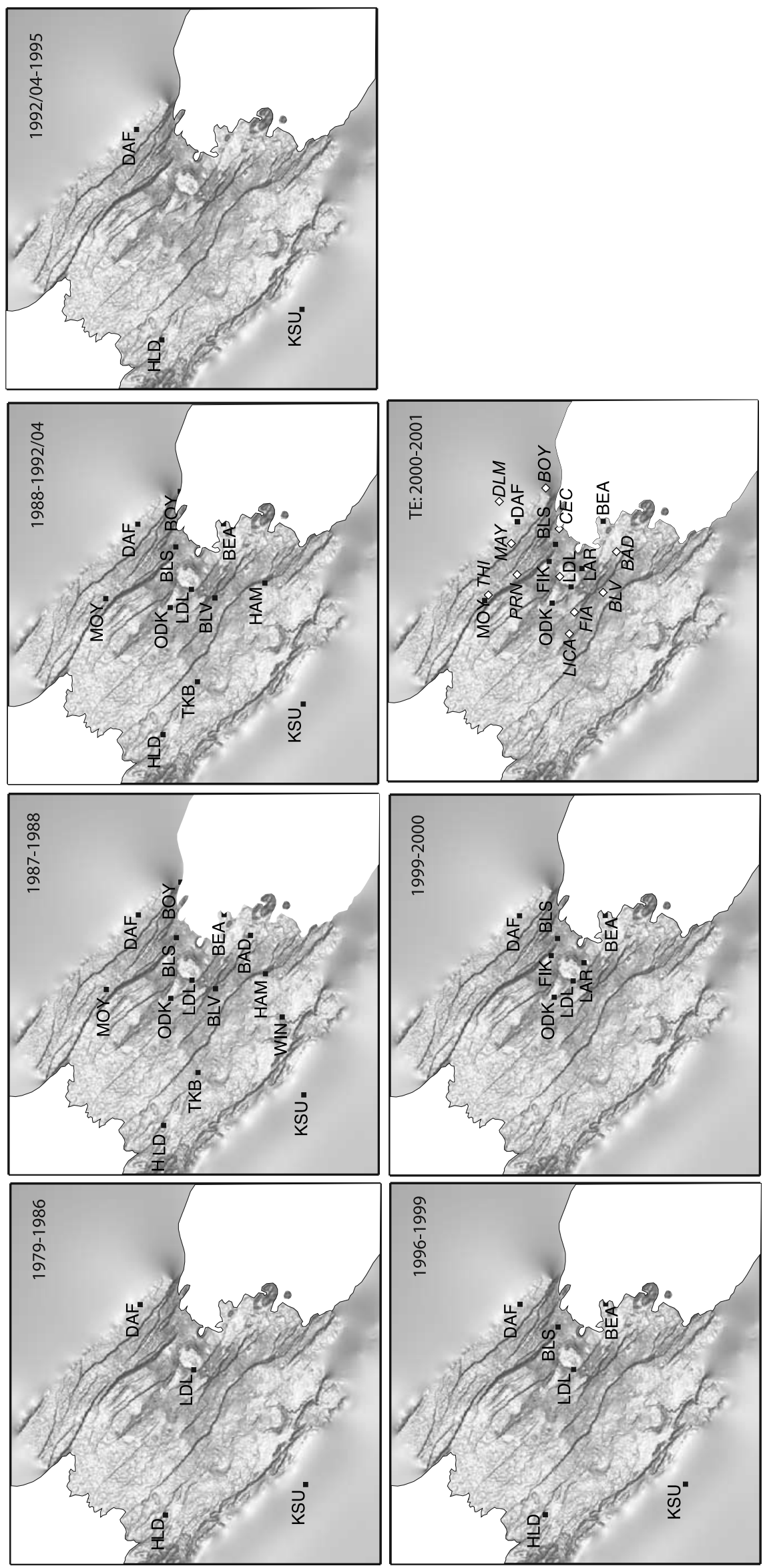

总

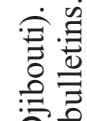

ด

हi

론?

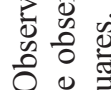

음

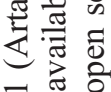

오․

골

ㅇํㅇ응

2

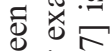

흥유

言宁

웡

덩 흘

E⿱ 80

응 흔

究

要量高

㟧

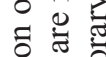

刍产

届焉要

i 氙

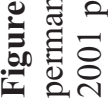


Table 1. Characteristics of Asal Seismological Network Between 1979 and 2001 (Arta Observatory, Djibouti)

\begin{tabular}{lcccc}
\hline $\begin{array}{c}\text { Record } \\
\text { Period }^{\mathrm{a}}\end{array}$ & $\begin{array}{c}\text { Number of } \\
\text { Stations }\end{array}$ & $\begin{array}{c}\text { Approximate } \\
\text { Detection } \\
\text { Threshold Magnitude }\end{array}$ & $\begin{array}{c}\text { Lateral } \\
\text { Uncertainty, } \\
\mathrm{km}\end{array}$ & $\begin{array}{c}\text { Vertical } \\
\text { Uncertainty, } \\
\mathrm{km}\end{array}$ \\
\hline $1979-1986$ & 4 & $\sim 1.3$ & $1-3$ & fixed to 5 \\
$1987-1988$ (TE) & 17 & $\sim 0$ & $<0.5$ & $<0.5$ \\
$1988-1992 / 04$ & 12 & 0.3 & $\sim 0.5$ & $\sim 1$ \\
$1992 / 04-1995$ & 4 & $1.3-1.9$ & $\sim 3$ & fixed to 5 \\
$1996-1999$ & 6 & $0.8-0.9$ & $<1$ & $\sim 2$ \\
$1999-2000$ & 7 & 0.3 & $<0.5$ & $<1$ \\
$2000-2001$ (TE) & 18 & $\sim-1.0$ & $<.5$ & $<0.5$ \\
\hline
\end{tabular}

${ }^{\mathrm{a}} \mathrm{TE}$, temporary experiment.

the rift has been opening at $6 \pm 1 \mathrm{~cm} / \mathrm{yr}$ (between $\mathrm{F}$ and $\delta$ footwalls; profile EP-DF, Figures $1 \mathrm{~b}$ and $\mathrm{S} 1 \mathrm{a})$, i.e., $\sim 4$ times faster than the long-term and far-field divergence rates (15 $\pm 2 \mathrm{~mm} / \mathrm{yr}$ [e.g., Kasser et al., 1987]). Since 1987, the opening has slowed to a rate of $\sim 1.5 \mathrm{~cm} / \mathrm{yr}$ [Vigny et al., 2007]. This second period is defined as "interrifting" in the literature [Cattin et al., 2005].

\section{Data Sets and Processing}

[14] We analyze the data recorded during the 1979-2001 period in the subaerial part of the rift, and during the 1992 2001 period in the Ghoubbet.

\subsection{Data in the Subaerial Part of Asal-Ghoubbet Rift}

[15] The number of operating seismometers since 1979 in the western half of the rift (Figure 2 and Table 1) has fluctuated in time due to difficult logistical conditions in the field and to political problems. Throughout the entire 19792000 period only earthquakes showing a signal-over-noise ratio greater than three at a minimum of three stations and within a time window of eight seconds were recorded.

[16] More than 2500 events were recorded in the 19792000 time span, and most of them were located by the observatory staff using a classical routine, Hypo71 [Lee and Lahr, 1975] (1-D velocity model from Lépine et al. [1972] and Ruegg [1975]). Uncertainties on hypocenter positions are variable according to their positions and time periods (Table 1).

[17] Throughout this paper the magnitudes have been calculated from the coda duration using the formula of Pechmann et al. [2001] established in the quite similar Yellowstone volcano-tectonic environment $(\mathrm{Md}=2.44$ $\log (\tau)-2.60$, where $\tau$ is the signal duration in seconds). Although they have not been calibrated with moment magnitudes, they constitute a coherent and homogeneous set.

3.1.1. The 1996-2000 "Relocated" Events

[18] We had access to the arrival times of all earthquakes recorded in the rift from 12 February 1996 to 9 September 2000, when the permanent network was dense. We first located the events using a standard procedure, Hypoinverse [Klein, 1978] with a 1-D velocity model from Ruegg [1975], and only retained those with horizontal uncertainty $<1.5 \mathrm{~km}$ and vertical one $<2 \mathrm{~km}$. This provided 829 events with mean lateral and vertical uncertainties of 717 and $682 \mathrm{~m}$, respectively (mean RMS of $0.035 \mathrm{~s}$ ). We then relocated these events using the 3-D crustal model determined by Doubre et al. [2007]. A total of $4304 \mathrm{P}$ and $1642 \mathrm{~S}$ wave arrivals were inverted using Simulps 12 [Evans et al., 1994] with the same grid as that used by Doubre et al. [2007, Figure 2b]. This led to the relocation of the 829 events with a lateral and vertical precision averaging 71 and $79 \mathrm{~m}$, respectively (Figure 3a). Auxiliary material Figure S2a compares the results from both location procedures. On average, the lateral, vertical and total distances between the 1-D and the 3-D locations are 670, 322 and $895 \mathrm{~m}$. More precisely, both lateral and vertical offsets are lower than a few hundred meters for events in the central part of the grid and larger than a few $\mathrm{km}$ for more distant events. The relocation procedure provided compact and shaped event clusters (auxiliary material Figure S2). Relocated hypocenters gather in narrow volumes close to some of the rift structures, such as the Fieale caldera rim and the fault $\delta$. Some of these volumes are also elongated along faults or rounded along the caldera rim. This confirms that the relocations are accurate and the 3-D crustal model is robust. In the following we will only consider the relocated hypocenters of the 1996-2000 events. They range between 0 and $10.38 \mathrm{~km}$ depth (Figures 3a and S3a) and have duration magnitudes between -1 and 2.3 (Figure S3b).

\subsubsection{The 1979-1999 Catalog of Hypocentral First Localizations}

[19] We also had access to the hypocentral parameters (i.e., time, latitude, longitude, depth, signal duration) determined by the observatory staff for 1950 events between 14 September 1979 and 12 November 1999. These parameters were obtained using Hypo71 and a 1-D crustal model with a Vp/Vs ratio of 1.81 [Ruegg, 1975]. From this population we removed the 1996-2000 events whose arrival times were available and used in our relocation procedure (see above). The remaining 1979-1999 events

Figure 3. Distribution of 1979-2001 events in subaerial section of AG Rift. Symbol size indicates duration magnitude; colors gives focal depth. (a) The 1996-2000 events from observatory catalogs, relocated in present study using the 3-D crustal model of Doubre et al. [2007]. (b) The 1979-1999 events as localized in observatory catalogs. (c) The 2000-2001 events recorded during temporary experiment of Doubre et al. [2007] and located with 3-D crustal model. 

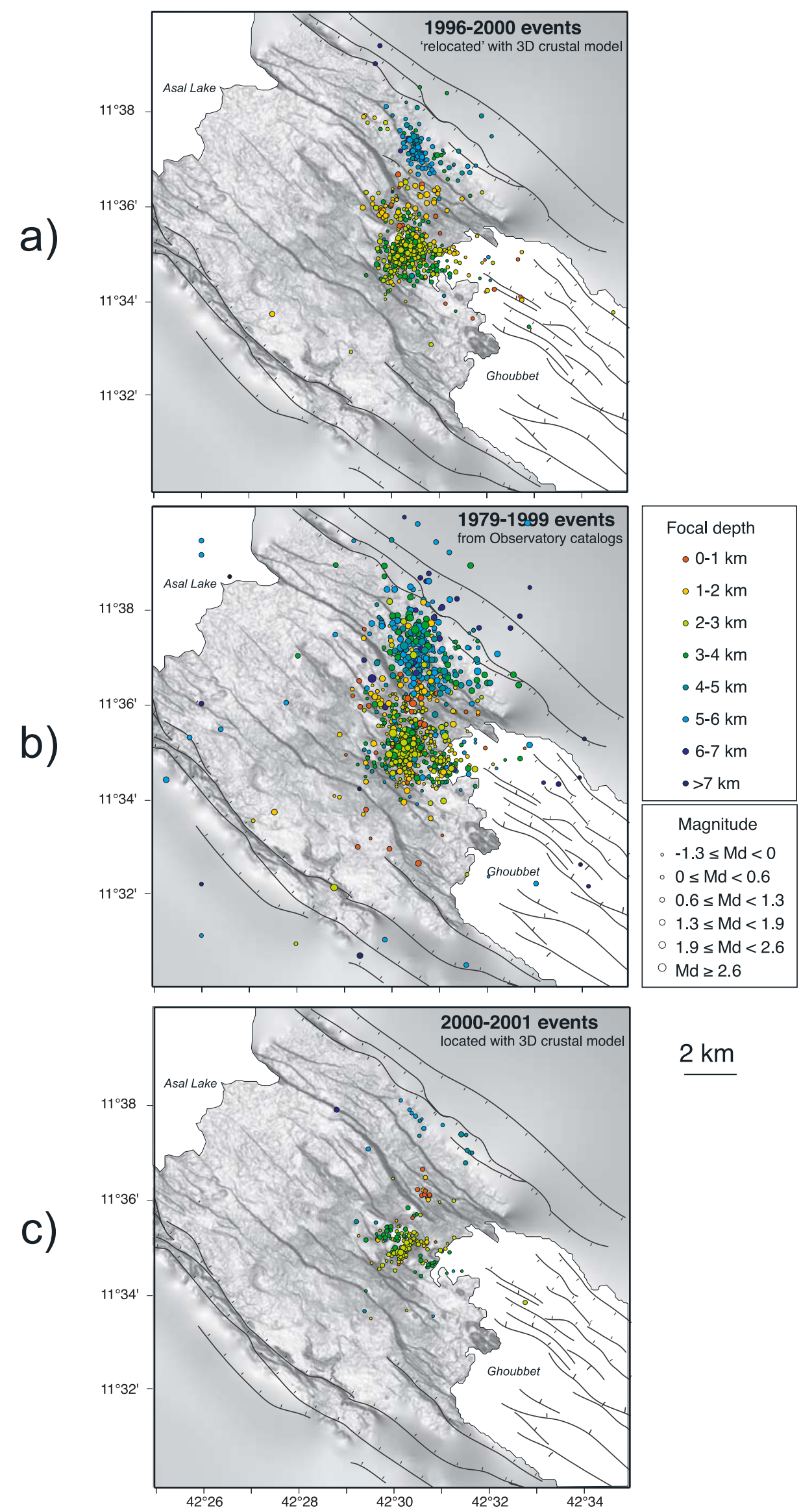

$2 \mathrm{~km}$

Figure 3

7 of 32 


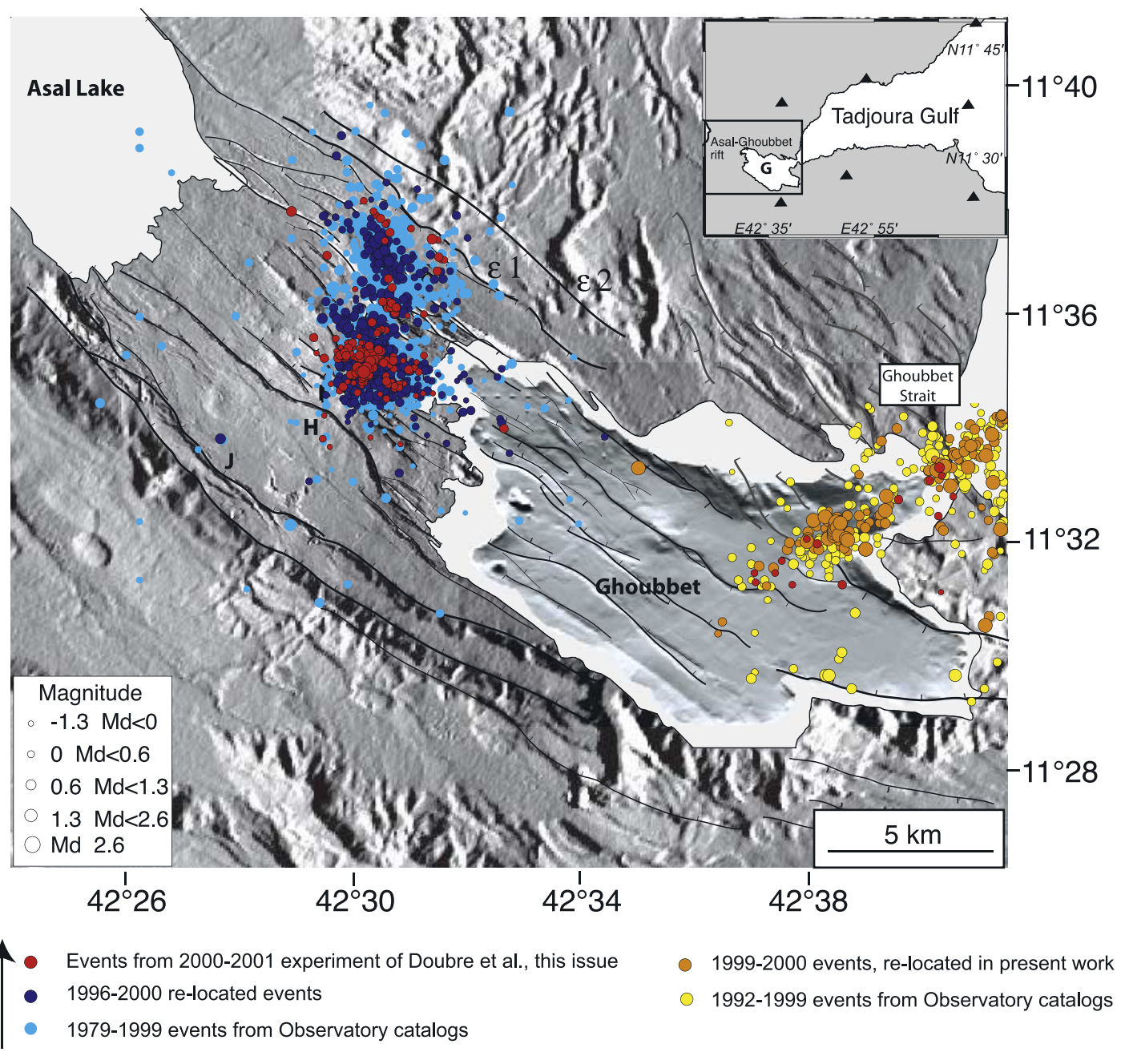

Figure 4. Distribution of 1979-2001 events in whole AG Rift. Colors distinguish the various data sets. Faults are as before. Faults in gray are those transferring strain between AG and Tadjoura Rifts (see Manighetti et al. [2001a] for details). Inset shows permanent seismological stations (triangles) in Ghoubbet and Tadjoura Gulf regions. G, Ghoubbet.

are plotted in Figure 3b. Their hypocenters range between 0 and $7.6 \mathrm{~km}$ depth (Figure S3a) while their duration magnitude varies between -0.8 and 2.8 (Figure $\mathrm{S} 3 \mathrm{~b}$ ).

\subsubsection{The 2000-2001 Temporary Experiment}

[20] To the previous data sets we add the 200 events located in the on-land part of the rift during the experiment conducted between 20 October 2000 and 22 March 2001 [Doubre et al., 2007] (Figure 3c). These events were located using a 3-D crustal velocity model, with lateral and vertical precisions of $\sim 40 \mathrm{~m}$. Their hypocenters range between 0 and $7.14 \mathrm{~km}$ depth (Figure S3a), while events have duration magnitudes between -1.0 and 2.5 (Figure S3b).

\subsection{Data in the Ghoubbet}

[21] The permanent network of the Arta Observatory also includes stations on the coasts of the Gulf of Tadjoura and the Ghoubbet (Figure 4, inset). The configuration of the "gulf network" has hardly changed over the last 20 years, so that two seismometers were continuously operating on either side of the Ghoubbet, together with three to five stations in the Gulf of Tadjoura and with the permanent Asal network. We here focus on the "Ghoubbet events" only, i.e., events having occurred in the Ghoubbet Basin, including its immediate shores, west of the Ghoubbet Strait (Figure 4).

\subsubsection{The 1992-1999 Catalog of Hypocentral First Localizations}

[22] From events recorded between 3 January 1992 and 17 January 1999, we only retained the 132 events having a horizontal uncertainty less than $1.5 \mathrm{~km}$, and a vertical uncertainty less than $2.0 \mathrm{~km}$ (Figure 4). These events range between 1.0 and $13.53 \mathrm{~km}$ depth (Figure S3a) and have duration magnitudes between -0.1 and 2.7 (Figure S3b). They are located with lateral and vertical uncertainties averaging 1.3 and $1.5 \mathrm{~km}$, respectively.

\subsubsection{The 1999-2000 Events}

[23] For events between 18 January 1999 and 24 October 2000 , the arrival times were available. We selected the events whose $\mathrm{P}$ and $\mathrm{S}$ wave arrivals were clearly identified 
at a minimum of six stations, and one station, respectively. We calculated hypocentral parameters using a Hypoinverse routine (1-D model from Ruegg [1975]; Vp/Vs = 1.81) and retained the 106 events located with horizontal uncertainties less than $1.5 \mathrm{~km}$ and vertical uncertainties less than $2 \mathrm{~km}$ (Figure 4). These events range between 1.03 and $11.29 \mathrm{~km}$ depth (Figure S3a), and have duration magnitudes between 0.0 and 2.7 (Figure S3b). They are located with lateral and vertical uncertainties averaging 700 meters.

\subsubsection{The 2000-2001 Temporary Experiment}

[24] To the two previous data sets we add the 15 events recorded in the Ghoubbet during the 5 months of the 20002001 experiment [Doubre et al., 2007] (Figure 4). The hypocenters range between 1.04 and $10.73 \mathrm{~km}$ depth (Figure S3a) and have duration magnitudes between -1 and 1.7 (Figure S3b). They are located with a lateral and vertical precision averaging 1.0 and $1.4 \mathrm{~km}$, respectively. Note that these large uncertainties are due to the small number of stations around the Ghoubbet.

\section{Spatial Distribution of the 1979-2001 Seismicity in the Rift}

\subsection{Overall Distribution}

[25] Figures 3 to 5 present the various data sets together providing the general picture of the seismic activity in the whole AG Rift since the last rifting episode.

[26] All recorded events have a small magnitude, between -1.0 and 2.8 (see also Figure S3b), and a shallow depth, everywhere less than $13.5 \mathrm{~km}$ (see also Figure S3a), and even less than $8 \mathrm{~km}$ in the central part of the rift. The localizations of the events from the different data sets overlap each other, demonstrating that seismic activity has stayed focused in the same spots over the 23 years of observation. This is particularly clear in the subaerial section of the rift (Figure 4). The distribution of colors is also similar in the three plots of Figure 3, showing that the data sets also superimpose at depth. The temporal consistence of the seismicity affecting these areas suggests that the uncertainties of the event parameters given a priori in Table 1 are largely conservative.

[27] Seismicity is not evenly distributed throughout the rift (Figure 4). Only two zones have been the sites of earthquakes for the period under study: a small zone in the NE part of the Ghoubbet and a larger zone in the central northern section of the subaerial rift. The Ghoubbet Basin is particularly free of earthquakes, as are the southern shoulder and the western half of the subaerial rift. Thus although most AG faults show evidence of recent, Holocene activity (section 2), almost none have produced earthquakes in the last 23 years. Likewise, although several recent volcanic edifices exist in the rift, including the 1978 Ardoukoba, almost none are associated with seismic activity.

[28] For each data set, the domain affected by seismicity in the subaerial rift is divided into three distinct zones between which only a few earthquakes were recorded (Figure 3). These zones cover the Fieale-SB area (eastern half of rift inner floor), the Disa Le Mallo (DLM) subrift, and part of the northern rift shoulder (mainly between faults $\delta$ and $\varepsilon$ ). Hypocentral depths are homogeneous within each zone, on the order of 2-4 km in the Fieale-SB area, $0-2 \mathrm{~km}$ in the DLM subrift, and 5-7 km in the northern shoulder.
Such a homogeneous focal depth distribution suggests that events within each zone share a common mechanical origin.

\subsection{Major Active Zones}

[29] Below, we analyze the seismic activity of the major zones listed above. Following Doubre et al. [2007], we assume that although small-magnitude ruptures in volcanotectonic environments may have various mechanical origins and may not necessarily result from slip on major faults, the location and geometry of the event clusters and their rupture mechanisms reveal larger-scale deformation on major structures. We therefore use the distribution of the recorded events, combined with the focal mechanisms calculated for some of the 2000-2001 earthquakes, as a guide for the identification of the major structures (either faults or volcanic features).

\subsubsection{Ghoubbet}

[30] Although the Ghoubbet floor is dissected by a dense network of $\mathrm{N} 120 \pm 5^{\circ} \mathrm{E}$ striking active normal faults [e.g., Audin et al., 2001], only 253 events were recorded in the basin in the last 10 years $(\mathrm{Md}-1.0-2.8$; depth $0.5-13.53 \mathrm{~km}$, mean $4.14 \mathrm{~km}$, Figure 4). All are in the zone where the Ghoubbet rift faults interact with the NNW striking normal and left-lateral faults that transfer extension between the AG and the Tadjoura Rift segments (Figure 4) (see Manighetti et al. [2001a] for details). Most events actually lie at the southern tip of these transfer faults (Figures 1a and 4). Thus the large majority of the Ghoubbet events most likely result from slip on the NNW striking transfer faults, while the actual rift faults are not associated with any clear seismicity. 4.2.2. Northern Rift Shoulder (North of $\gamma 2$ Surface Trace)

[31] About 400 events ( $\mathrm{Md}-0.9-2.8)$ were recorded in the northern rift shoulder, north of the DLM subrift (Figures 3 and 5). Most epicenters spread between the surface traces of faults $\gamma 2$ and $\varepsilon 1$, while hypocenters range between 3 and $6 \mathrm{~km}$ depth. Most events gather below and on either sides of the $\delta$ surface trace (Figure 5a). This is particularly clear for the relocated events that shape a narrow, NW trending cluster at the vertical of the fault trace (Figure 3a). However, unless fault $\delta$ has a vertical plane to $\sim 6 \mathrm{~km}$ depth, it cannot be responsible for these events. Projected along an acrossaxis section (Figure 5b), these events form a narrow, rectangular zone $\left(<0.5 \times 2 \mathrm{~km}^{2}\right)$ dipping $65 \pm 5^{\circ}$ to the southwest, which likely corresponds to the extension of the $\varepsilon 1$ fault plane at depth. The same relationship is inferred farther east (Figure 5c) although some of the events are more likely related to slip along fault $\varepsilon 2$. The latter is inferred to have a similar, $60 \pm 5^{\circ} \mathrm{SW}$ dipping plane down to 5-6 km along the cross section P2 (Figure 5c). The easternmost events plotted on the cross sections P3-P5 are more sparse, yet compatible with slip (or deformation around) on both faults $\varepsilon 1$ and $\varepsilon 2$ (Figures $5 \mathrm{~d}-5 \mathrm{f}$ ).

[32] Hence, although the $\varepsilon$ fault system does not show any clear evidence of Holocene activity, it may be currently slipping and/or sustaining microruptures on or around its major planes. The fault system does not slip along its entire surface, however, but along small patches located at 5-6 km depth, possibly at its downward edge. The patch on $\varepsilon 1$ represents a volume of at most $2.7 \times 1 \times 2 \mathrm{~km}^{3}$ surrounding the main fault plane or a surface of $\sim 5.4 \mathrm{~km}^{2}$ on the fault plane. 
(a)

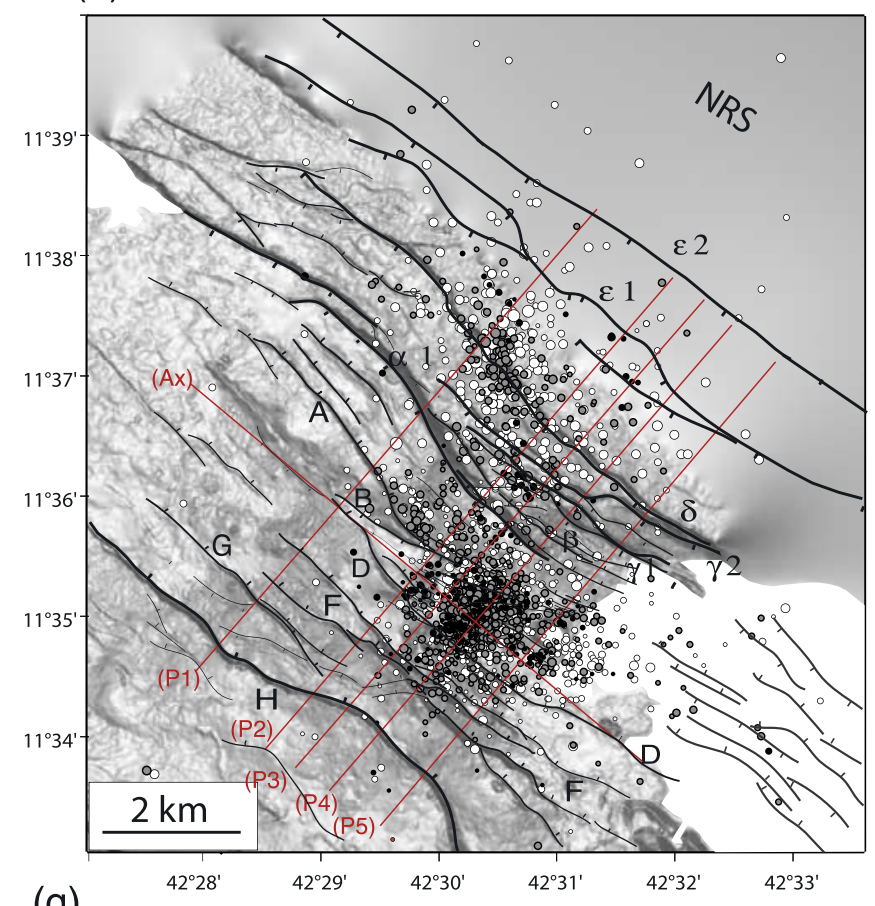

(g)

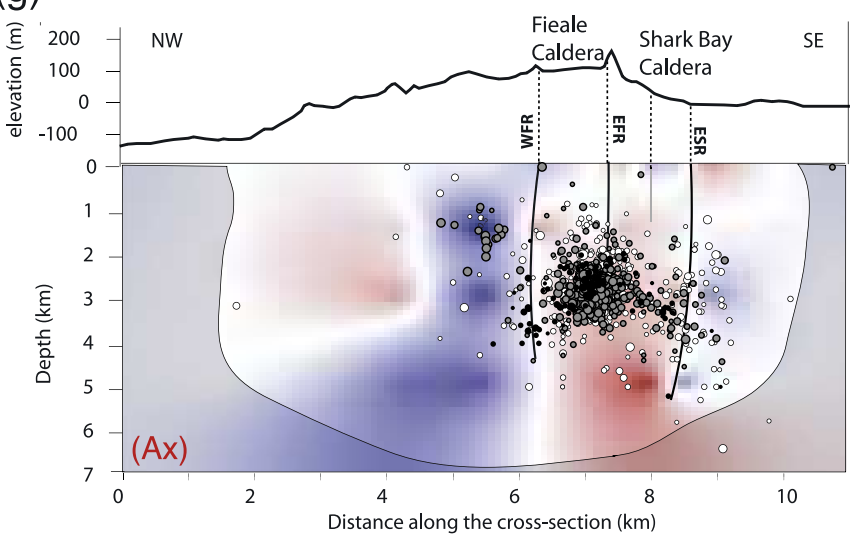

(c)
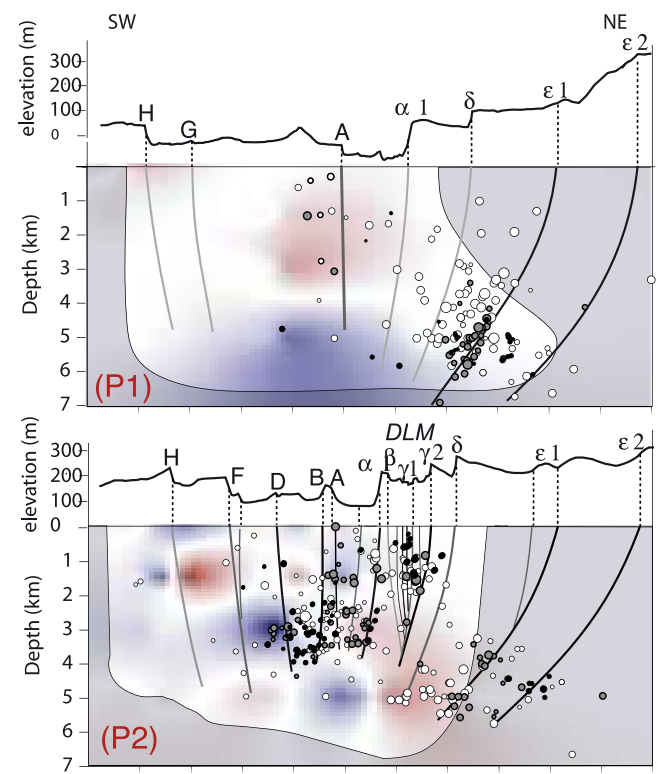

(d)

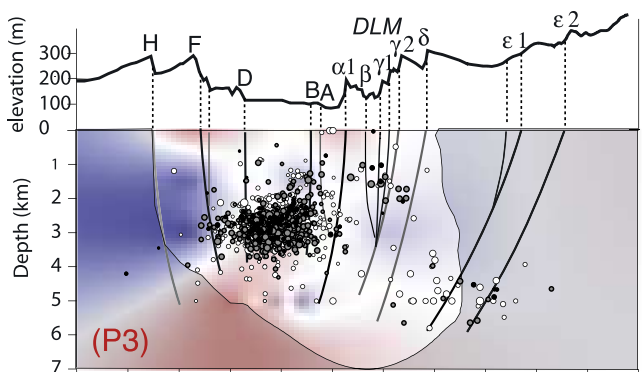

(e)

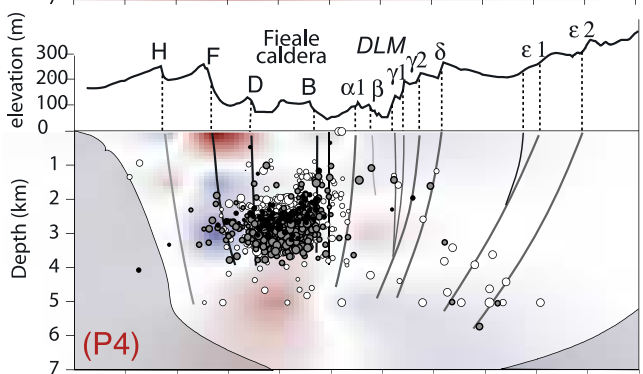

(f)

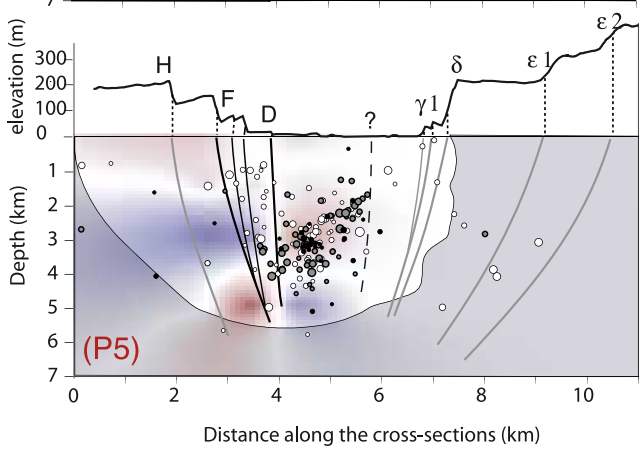

Figure 5. Distribution of 1979-2001 events in subaerial section of AG Rift. (a) Epicenter distribution. The three data sets are distinguished by fill. Red lines are cross sections described in Figures $5 \mathrm{~b}-5 \mathrm{~g}$. Faults are as before. $(\mathrm{b}-\mathrm{g})$ Projection of events on cross sections located in Figure 5a. In each plot, events are those whose epicenter is less than $400 \mathrm{~m}$ away from the cross section line. P wave velocity anomalies and fault projections are from Doubre et al. [2007]. Gray zones are unresolved. See text for discussion on faults and volcanic features. DLM, Disa Le Mallo subrift. 
[33] Finally, a few events whose epicenters are between the surface traces of faults $\gamma 2$ and $\delta$ are likely associated with slip on or around the $\delta$ plane (see Figures $5 \mathrm{~b}-5 \mathrm{e}$ ). We infer that fault $\delta$ may also be currently slipping or sustaining distributed deformation, and have a $75 \pm 5^{\circ} \mathrm{SW}$ dipping plane down to $\sim 5 \mathrm{~km}$.

\subsubsection{Disa Le Mallo Northern Subrift}

[34] 115 events $(\mathrm{Md}-0.5-2.1)$ were recorded in the DLM subrift, with 58 having $\mathrm{Md}>1.0$ (Figure 5a). Most epicenters spread between the antithetic faults $\beta$ and $\gamma 2$. Events lie between 0 and $2 \mathrm{~km}$ depth and are concentrated in a small, narrow, NW elongated volume $(\sim 1 \times 0.5 \times$ $2 \mathrm{~km}^{3}$ ) extending in the central western part of the subrift inner floor, in the hanging wall of fault $\gamma 1$, where fissure density is high. On a perpendicular cross section this volume appears vertical (Figure 5c). The location, geometry and shallow depth of this volume, together with the numerous tensile cracking focal mechanisms determined in that area [Doubre et al., 2007], suggest that most DLM events result from the opening or closing of some of the subvertical shallow fissures that dissect the subrift inner floor (Figures 5a, 5c, and 5d). A few deeper events, mostly in the hanging walls of faults $\gamma 1$ and $\gamma 2$, are likely related to slip on these two faults (at least $\gamma$ ) and on fault $\delta$. This would imply that faults $\gamma 1, \gamma 2$, and $\delta$ have steep, almost vertical planes at least to $5 \mathrm{~km}$ depth.

\subsubsection{Alpha Northern Bounding Fault System}

[35] About 265 events (Md -1.0-2.6) are found in the hanging wall of fault $\alpha 1$, roughly aligned along its scarp and at a horizontal distance less than $\sim 500 \mathrm{~m}$ from it (Figures 3 and 5a). Most events are concentrated at the southeastern tip of the fault, close to Fieale, where they lie between 1.5 and $4 \mathrm{~km}$ depth. Events farther west are deeper, down to $7.1 \mathrm{~km}$. Altogether, the events reveal slip on, or deformation around, the $\alpha 1$ fault plane, implying the latter has a $80 \pm 5^{\circ}$ dip to the southwest down to at least $4 \mathrm{~km}$ (Figures $5 \mathrm{c}-5 \mathrm{e}$ ). The recorded events affect a volume of $\sim 1.5 \times 0.4 \times 1 \mathrm{~km}^{3}$, or a surface of $\sim 1.5 \mathrm{~km}^{2}$ on the fault plane.

\subsubsection{Fieale Area}

[36] As observed during the 2000-2001 temporary experiment [Doubre et al., 2007], the greatest density of events is found in the easternmost part of the subaerial rift inner floor, in the Fieale area defined as the region between the F and B- $\alpha$ fault systems, and from $42^{\circ} 29^{\prime} \mathrm{E}$ to $42^{\circ} 32^{\prime} \mathrm{E}$. This area thus encompasses the Fieale caldera, its smaller adjacent $\mathrm{f}$ and SB calderas and the western Ghoubbet coast (Figure 1a). More detailed descriptions of the zone are provided by Doubre et al. [2007].

[37] The $\sim 1500$ events ( $\mathrm{Md}-1.1-2.6$ ) recorded in the Fieale area reveal that the seismic activity in this volcanic area is mainly continuous since the last 1978 rifting episode (Figure 3). Especially for the relocated events (Figures 3a, $3 \mathrm{c}$, and 5), the epicenters are not evenly distributed in the whole zone but are grouped into a few major clusters. The denser cluster overlays the Fieale caldera. Another more sparse group of events extends below and around the SB caldera, while another smaller event group is identified at the southeastern termination of fault A (hanging wall). Most remaining events are distributed below the crater $f$, and along the surface trace of fault D. Such a heterogeneous distribution suggests that distinct structures are responsible for the seismicity in that zone.

[38] The epicenters that overlay the Fieale caldera form two distinct clusters (Figures 3, 5a, and 5g). One overlies the western section of the caldera rim between faults D and $\mathrm{B}(\sim 120$ events, $\mathrm{Md}-1.0-2.6)$. The second, more dense one ( $\sim 790$ events, $\mathrm{Md}-1.0-2.5)$, covers the entire eastern half of the caldera including its eastern rim section, also between faults D and B. Hypocenters of the western group are between 0 and $5.0 \mathrm{~km}$ depth, with most events clustering at $\sim 4 \mathrm{~km}$. The events are vertically aligned along the interface that separates the central pipe of hot rocks from its surrounding high-velocity annulus, and interpreted as a subvertical ring fault (WFR, Figure 5g) (see Doubre et al. [2007] for details). Hypocenters of the eastern group events gather in a broader and more dense cluster extending between $\sim 2$ and $3.5 \mathrm{~km}$ depth, directly below the eastern section of the Fieale caldera rim (Figure 5g). Following Doubre et al. [2007], we suggest that the western and eastern events are associated with slip on, or deformation around the subvertical Fieale ring fault planes (WFR and EFR, Figure $5 \mathrm{~g}$ ). The lack of seismicity below $3.5-4 \mathrm{~km}$ suggests either that the Fieale ring faults do not extend deeper, or that aseismic deformation occurs below $4 \mathrm{~km}$.

[39] Only a few events are found between the two major clusters described above, in the center of the Fieale caldera, between the surface traces of faults D and B (Figure 5a). Their hypocenters are at an intermediate depth $(\sim 3 \mathrm{~km})$ between the two groups (Figure $5 \mathrm{~g}$ ). No event is recorded below that depth.

[40] Observed on across-axis sections (Figures 5d and $5 \mathrm{e})$, the "Fieale" events gather within a $\sim 1.5-\mathrm{km}$-thick and $1.5-\mathrm{km}$-wide volume of brittle material capping the central pipe of hot rocks. This brittle volume is bounded by the subvertical D and B fault planes and is dipping southwestward by $15-20^{\circ}$. On the along-axis cross section, that volume appears more discontinuous (Figure $5 \mathrm{~g}$ ). It is $\sim 1.5 \mathrm{~km}$ thick and $\sim 1 \mathrm{~km}$ wide, shallower to the east (maximum depth $\sim 3.5 \mathrm{~km}$ ), and it deepens westward (up to $4-4.5 \mathrm{~km}$ ) so that it apparently dips toward the northwest by $35-40^{\circ}$. From these observations we conclude that below the Fieale caldera, a $\sim 2.2 \mathrm{~km}^{3}\left(1.5 \times 1.5 \times 1 \mathrm{~km}^{3}\right)$ volume of seismogenic material has been rupturing for the last 23 years on top of the central thermal anomaly zone.

[41] As noted by Doubre et al. [2007], events recorded in the Shark Bay (SB) area share similarities with the Fieale events. All events are also enclosed between fault D and a northern limit that would coincide with the eastward prolongation of the B fault system (Figures 5a and 5f). Along a NW trending cross section, the SB events concentrate between 2 and $4 \mathrm{~km}$ at the top of the thermal anomaly. To the west they merge with the easternmost Fieale events. To the east they do not extend farther than the subvertical discontinuity separating the central hot pipe from the highvelocity host rocks and interpreted as the eastern SB ring fault at depth (ESR, Figure 5a) [Doubre et al., 2007]. Altogether, the SB events mainly concentrate within a narrow, $<1-\mathrm{km}$-thick and 1.5-km-wide, SE dipping $\left(\sim 45^{\circ}\right)$ volume stretching from the eastern Fieale to SB ring faults. On a NE trending cross section, that volume dips southwestward by $\sim 45^{\circ}$ between the $\mathrm{D}$ and possibly $\mathrm{B}$ fault planes (Figure 5f). From these observations we suggest that 
(a)

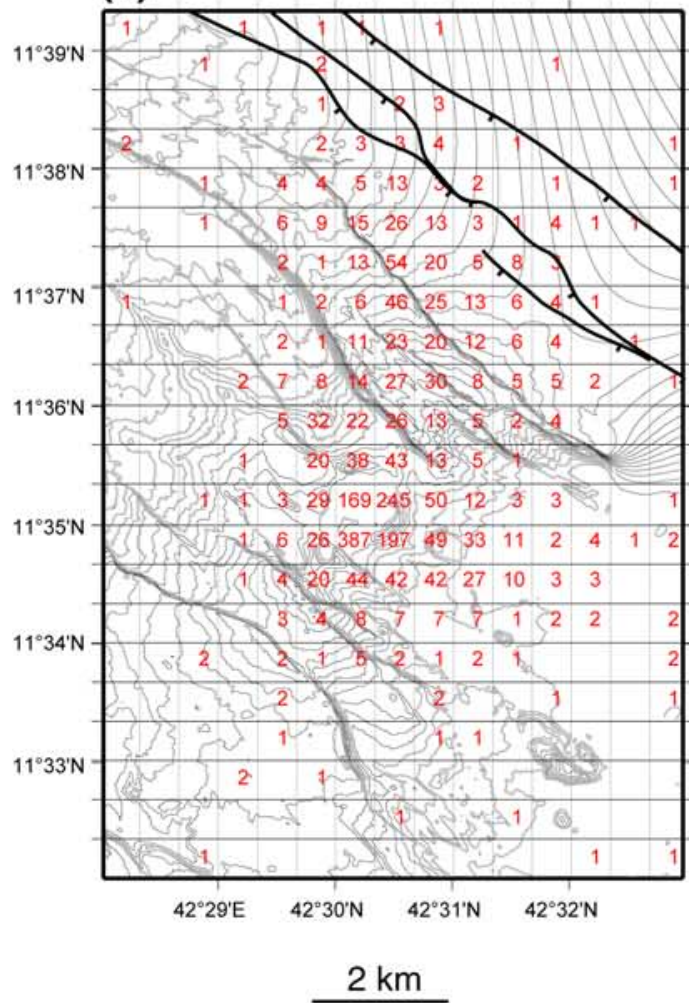

(c)

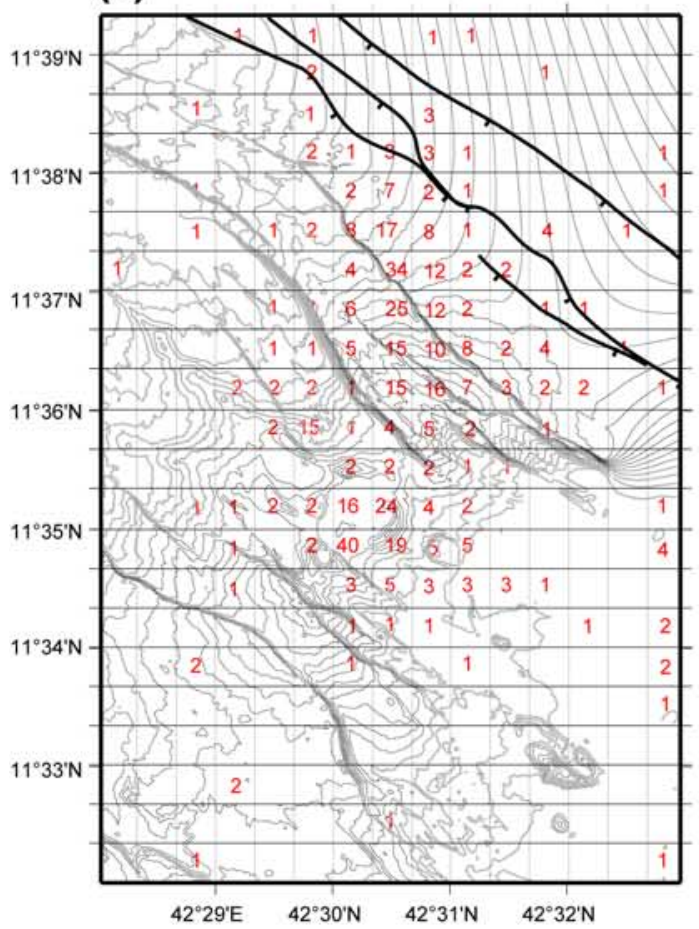

(b)

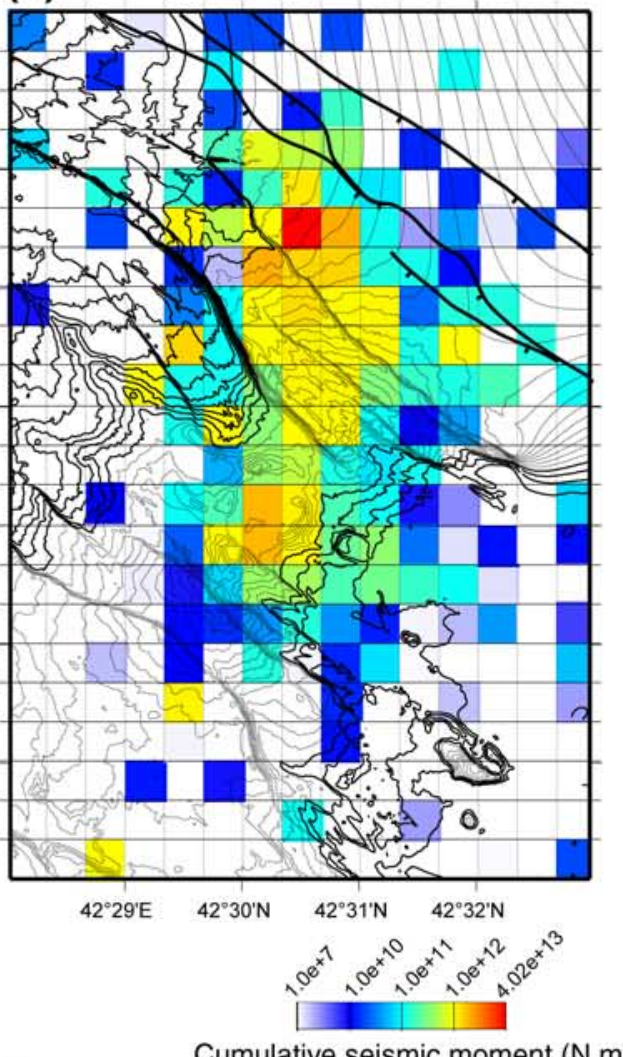

(d)

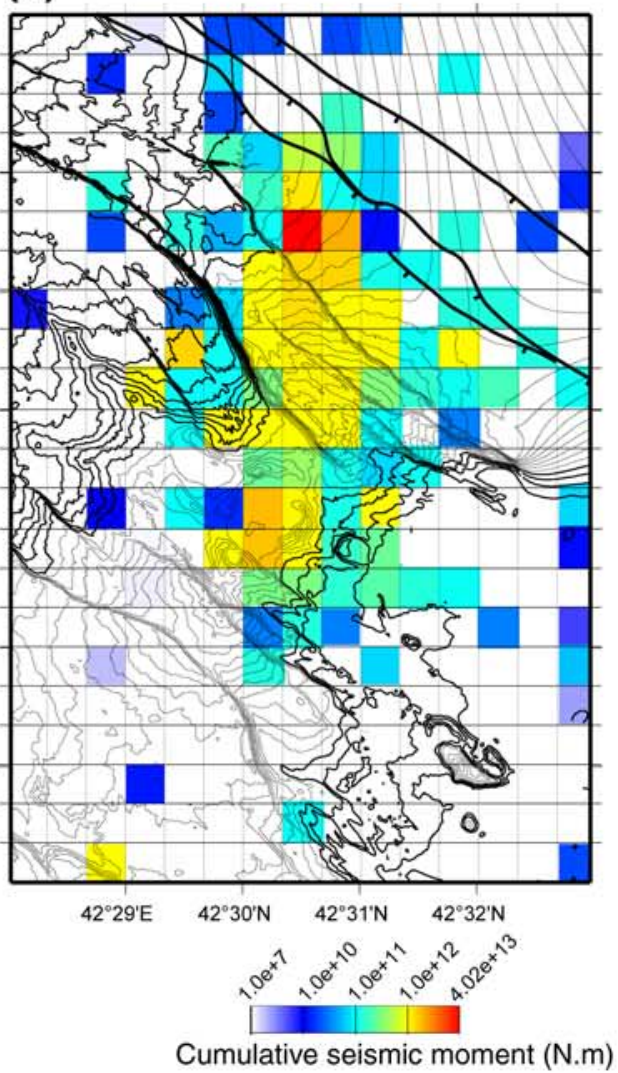

Figure 6 
$\mathrm{a} \sim 2.2 \mathrm{~km}^{3}\left(1.5 \times 1.5 \times 1 \mathrm{~km}^{3}\right)$ volume of seismogenic material has been rupturing for the last 23 years on top of the thermal anomaly zone, between Fieale and the SB caldera.

[42] The few events whose epicenters plot between the surface traces of faults $F$ and D mainly underlie the caldera $f$ (Figure 5a). As the shallowest Fieale events, most extend at $\sim 3-3.5 \mathrm{~km}$ depth, (Figures $5 \mathrm{c}-5 \mathrm{e}$ ) and form a cluster dipping southwestward similar to the volume formed by the microevents below the Fieale caldera (Figure 5d). This suggests that the events underlying the crater $f$ may result from processes similar to those responsible for the Fieale events. This "cluster f" is bounded to the south by the F fault plane and reveals that the fault F dips steeply northeastward by $75 \pm 5^{\circ}$ (Figures $5 \mathrm{~d}$ and $5 \mathrm{e}$ ). From all observations above, we suggest that the brittle volume at the roof of the central hot rock pipe may have a total size on the order of $4-7.5 \mathrm{~km}^{3}\left(1-1.5 \times 2 \times 2-2.5 \mathrm{~km}^{3}\right)$.

[43] Finally, the group of $\sim 40$ events at the base of the A fault scarp have various focal depths from 0 to $5 \mathrm{~km}$, and most of them appear vertically aligned below the A fault surface trace (Figures $5 \mathrm{~b}$ and $5 \mathrm{c}$ ). If slip on $\mathrm{A}$ is responsible for most events recorded in this area, we infer that fault A has a subvertical plane at least down to $3.5-4 \mathrm{~km}$.

\subsubsection{Southern Rift Shoulder}

[44] The southern shoulder of the rift, defined as the whole region south of fault $\mathrm{F}$, is affected by only 37 events (Md -1.2-2.0) during the entire period of observation. This shows an asymmetry on the spatial distribution of the seismic activity within the rift. Events are too sparse to constrain the geometry at depth of the southern fault planes. Only a few events located between faults $\mathrm{H}$ and $\mathrm{F}$ suggest that the fault $\mathrm{H}$ has a steep plane $\left(\sim 80 \pm 5^{\circ}\right)$ at least to a depth of $\sim 4 \mathrm{~km}$ (Figures $5 \mathrm{~d}-5 \mathrm{f}$ ).

\subsection{Distribution of Seismic Energy}

[45] Using a formula extrapolated from large earthquakes to small-magnitude events $\left(\log \mathrm{M}_{0}=1.5 \times \mathrm{Md}+9\right.$; with $\mathrm{M}_{0}$ the seismic moment [Kanamori and Anderson, 1975]), we calculated both the cumulative and average seismic moment in each $20 \times 20 \mathrm{~s}^{2}$ mesh of a grid covering the central rift section (each mesh is $\sim 617 \times 605 \mathrm{~m}^{2}$, i.e., much larger than the rupture size of any events of our data set). The number of events and the cumulative seismic moment in each mesh are shown in Figures $6 \mathrm{a}$ and $6 \mathrm{~b}$, respectively. Figures $6 \mathrm{c}$ and $6 \mathrm{~d}$ are similar to Figures $6 \mathrm{a}$ and $6 \mathrm{~b}$, but for events with $\mathrm{Md} \geq 1.0$. Figure $6 \mathrm{~b}$ shows that the Fieale caldera and the northern rift shoulder (including the western termination of the DLM subrift) are the two zones where most seismic energy was dissipated over the last 23 years. The maximum cumulative moment is on the same order, and reaches $1.3 \times 10^{13} \mathrm{~N} \mathrm{~m}$ in Fieale and $4.0 \times 10^{13} \mathrm{~N} \mathrm{~m}$ in the northern shoulder. In contrast, the number and size of events contributing to these maximum moment releases are different. While 387 small-magnitude events are involved in the total energy released in Fieale $(90 \%$ of the events have
Md $<1.0)$, only 26 larger earthquakes $(60 \%$ of the events have a $M d>1.0$ ) contribute to the maximum energy released due north of the central section of fault $\delta$. This observation can be generalized to the total moment released in the two zones. The total cumulative moment reaches $3.2 \times 10^{13} \mathrm{~N} \mathrm{~m}$ in Fieale and $1.1 \times 10^{14} \mathrm{~N} \mathrm{~m}$ in the northern shoulder within volumes of similar size $\left(\sim 2 \times 2 \times 2 \mathrm{~km}^{3}\right.$; the zones considered are those where $\left.\mathrm{M}_{0}>10^{12} \mathrm{~N} \mathrm{~m}\right)$. Small and numerous earthquakes contribute to that release in the Fieale area, whereas larger and fewer events release the seismic moment in the northern rift shoulder.

[46] From these results we conclude that seismic activity has been low in the rift over the last 23 years (at least in its emerged part) since the total energy dissipated is at most similar to that which would be produced by an "equivalent" Md $\sim 3.0$ earthquake in the Fieale area and a Md $\sim 3.4$ earthquake in the northern shoulder area, while the total energy produced in the whole subaerial section of the rift $\left(\sim 1.77 \times 10^{14} \mathrm{~N} \mathrm{~m}\right)$ is at most equivalent to that which a single $\mathrm{Md} \sim 3.5$ earthquake would produce.

[47] Figure 7 shows the frequency-magnitude plots drawn from the total population of events recorded in the subaerial section of the rift (Figure 7a), from those in its inner floor (Figure $7 \mathrm{~b}$ ), and from those pertaining to the major active zones described before (Figures 7c-7f; note that the latter populations can only be approximately defined). In all plots, the linear square fit regression lines reveal $b$ values between 1 and 1.5. This confirms that small-magnitude earthquakes have dominated the seismic activity of the rift in the last 23 years, including along the faults.

\section{Temporal Evolution of Seismicity in the Rift}

[48] Although the catalog is complete above magnitude $\sim 0.0-0.5$ only throughout the $1979-2001$ period, the available data are continuous and dense enough to allow the examination of the temporal evolution of seismicity. Since data in the Ghoubbet only cover the 1992-2000 period and reveal low activity in this part of the rift over this time span, they are not included in the following analysis.

[49] Figure 8a confirms that the amount of energy dissipated in the rift has varied over time, together with a change in the locus of greater dissipation and in the frequency and number of events (compare Figures $8 \mathrm{~b}$ and $8 \mathrm{c}$; see also dashed line in Figure 8a). Three major periods are identified (Figure 8a), which we refer to as "phases 1, 2 and 3" (Ph1, $\mathrm{Ph} 2, \mathrm{Ph} 3)$ in the following. Events from these three phases are presented in Figure 9. More detailed temporal evolutions described below are documented in a series of auxiliary material (Figures S4-S11).

\subsection{Phase 1 (1979-1986)}

[50] From 1979 to 1986, about two thirds of the total seismic energy was released through a large number of Md $\geq 1.0$ events concentrated below the northern rift shoulder ( $\sim 94 \%$ of total number; compare gray and black

Figure 6. Distribution of seismic moment release in subaerial section of AG Rift over the 1979-2001 period. (a) Number of events within each $20 \times 20 \mathrm{~s}^{2}$ grid cell. (b) Cumulative seismic moment released by events located within each $20 \times 20 \mathrm{~s}^{2}$ grid cell. (c) Number of events with $\mathrm{Md} \geq 1.0$ within each $20 \times 20 \mathrm{~s}^{2}$ grid cell. (d) Cumulative seismic moment released by events located within each $20 \times 20 \mathrm{~s}^{2}$ grid cell. 
a) Whole subaerial section of AG rift

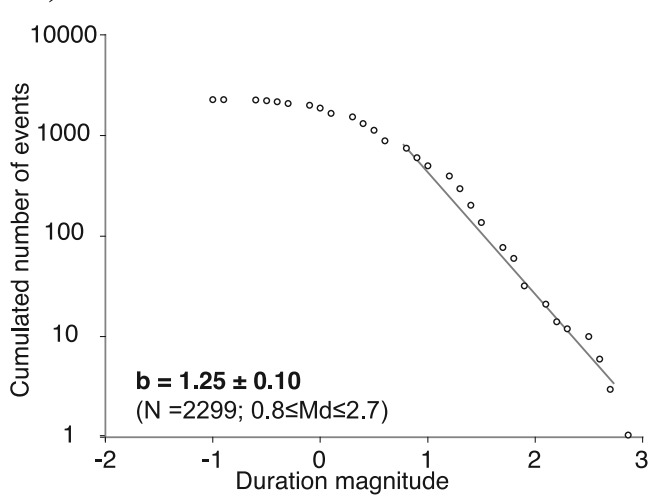

b) Subaerial rift inner floor

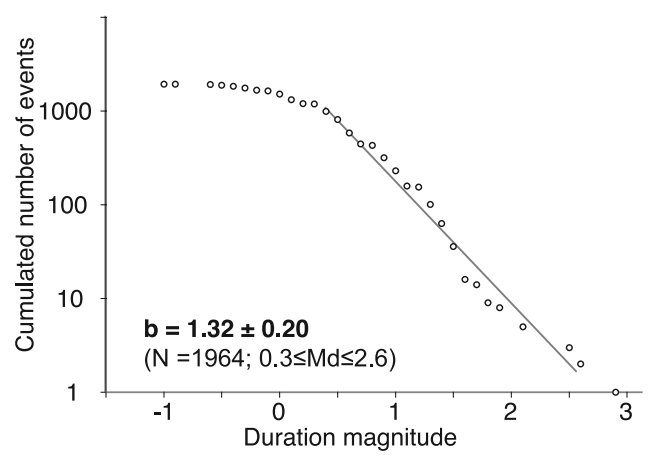

c) Northern rift shoulder

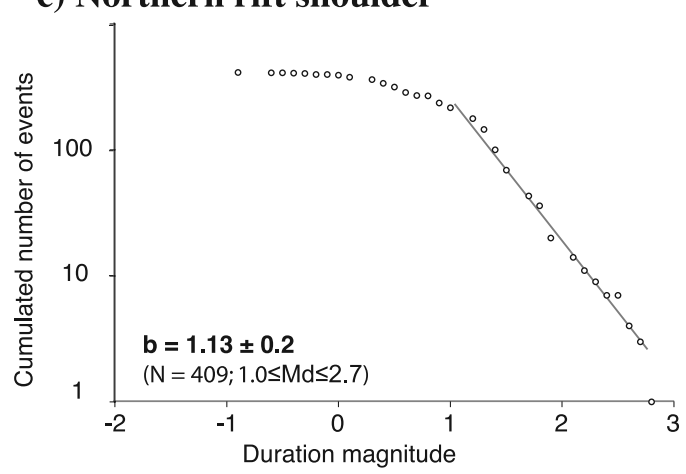

d) Disa Le Mallo Subrift

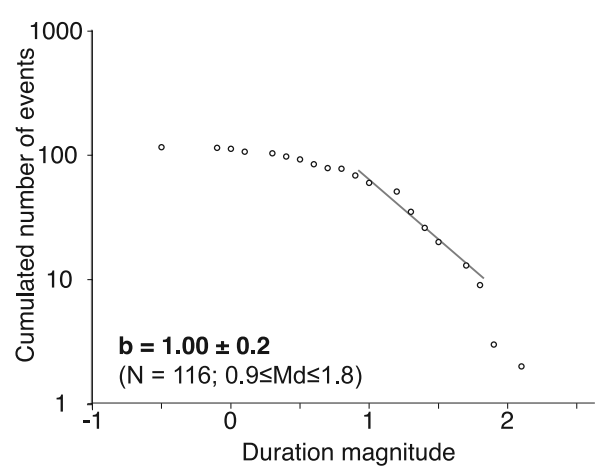

e) B fault

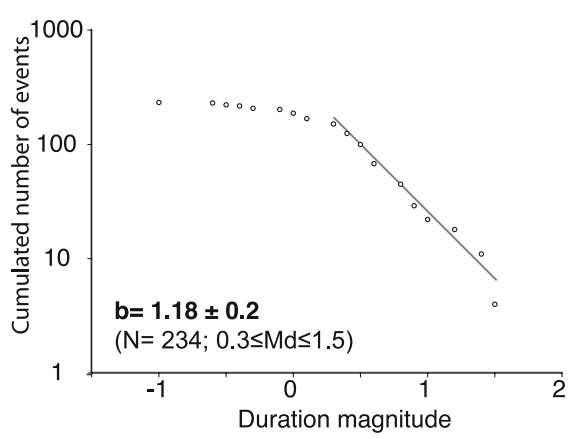

f) D fault

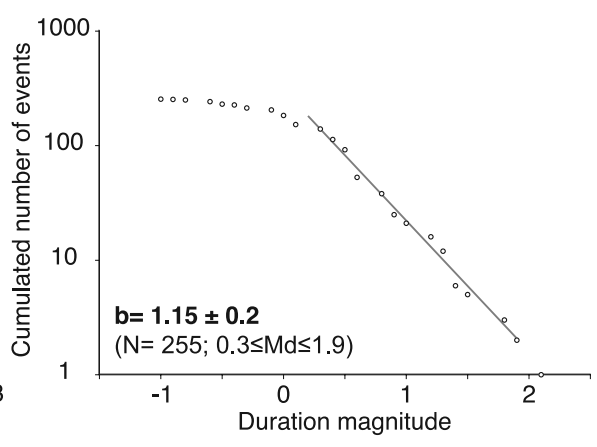

g) Area enclosed between B and D faults

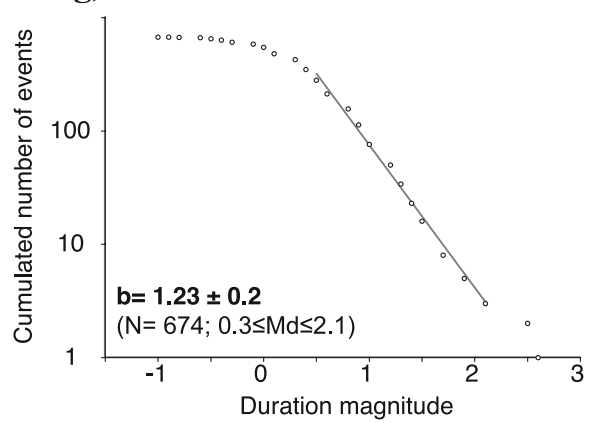

Figure 7. Frequency-magnitude plots for 1979-2001 events in subaerial section of AG Rift. Definition of the various populations of events can only be approximate. Semilog plots depict the relation $\log (\mathrm{N})=\mathrm{a}-\mathrm{b} * \mathrm{M}$, with $\mathrm{N}$ the cumulative number of events having a magnitude $\geq \mathrm{M}$; [Gutenberg and Richter, 1944]. (a) In whole subaerial rift section; (b) in subaerial rift inner floor; (c) in northern rift shoulder; (d) in DLM subrift; (e) in close vicinity of fault B; (f) in close vicinity of fault $\mathrm{D}$; and $(\mathrm{g})$ in area enclosed between the $\mathrm{B}$ and $\mathrm{D}$ facing faults. 
(a)

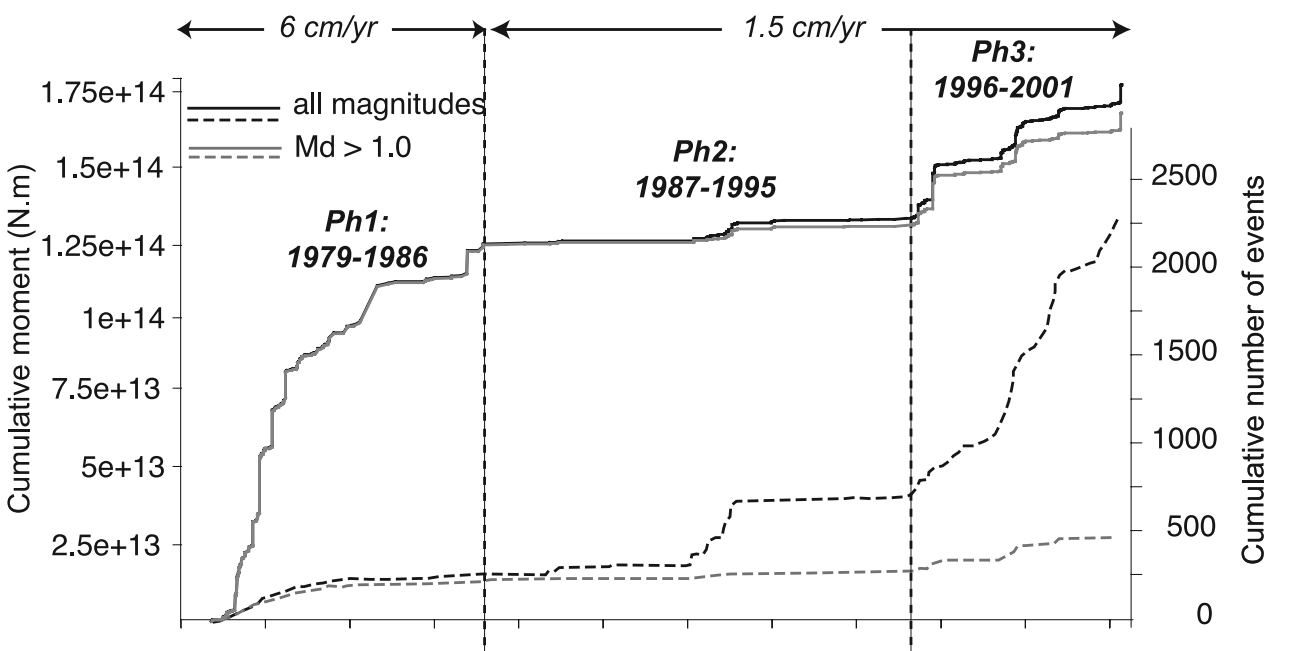

(b)

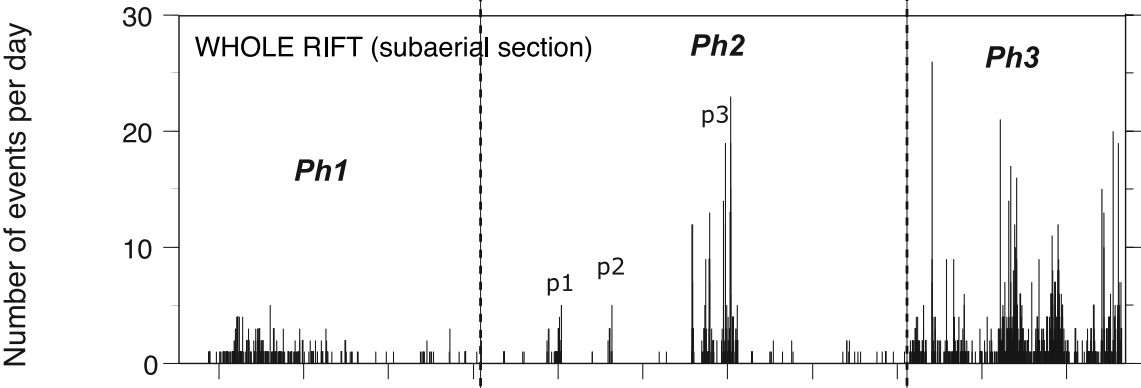

(c)

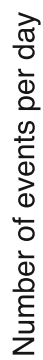

(d)

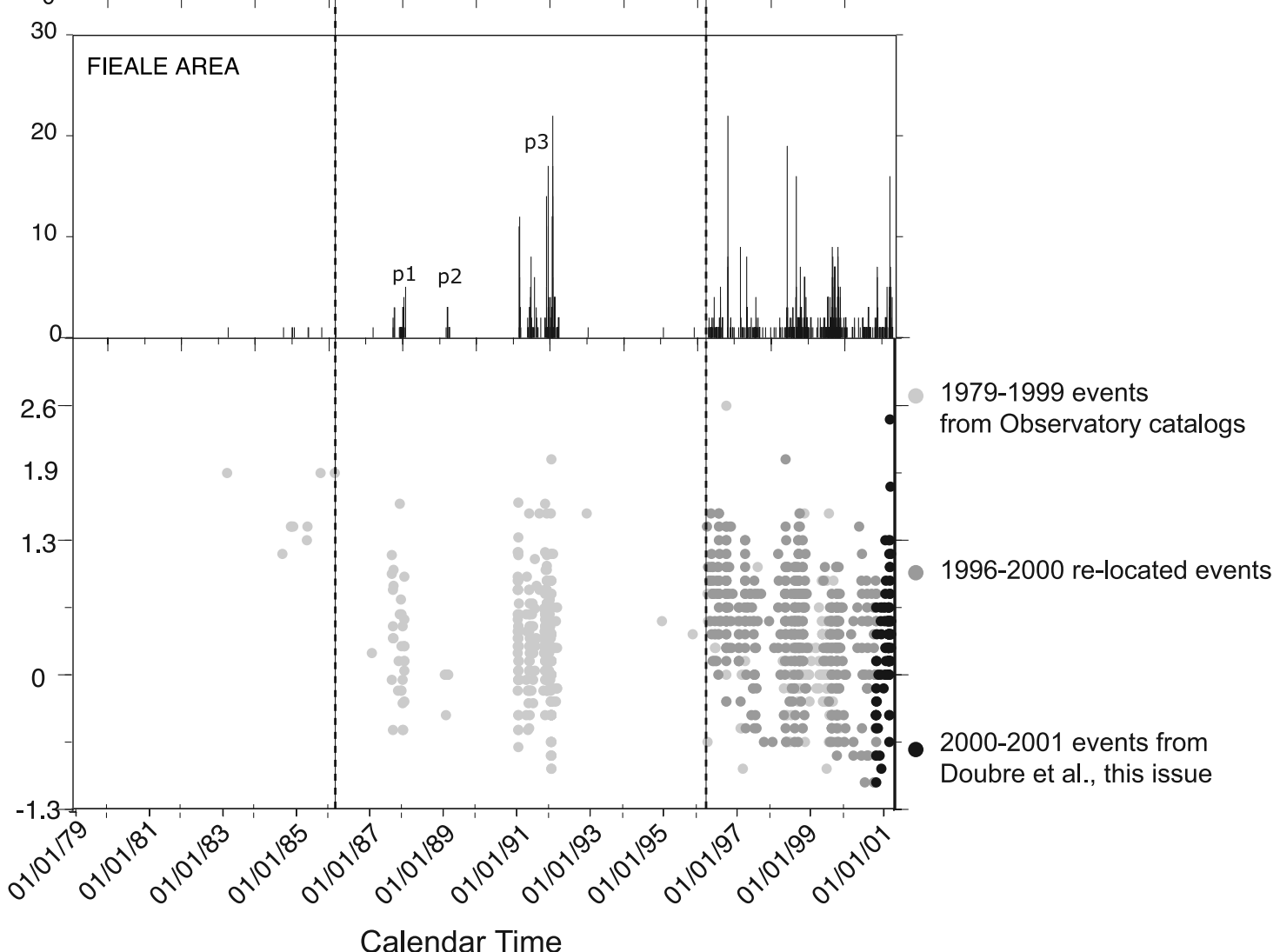

Figure 8 


\section{p3 (from Ph2)}

(e)

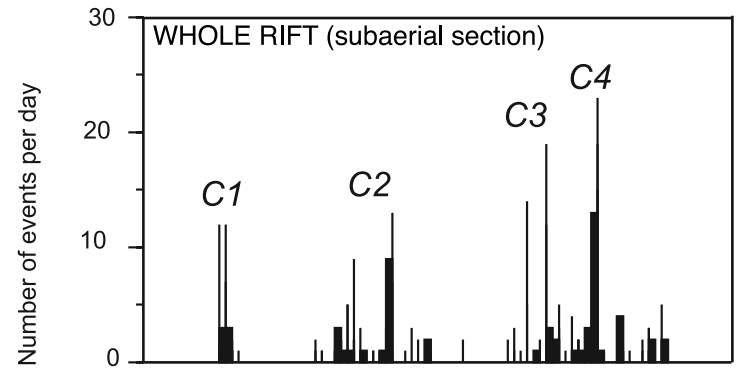

(f)

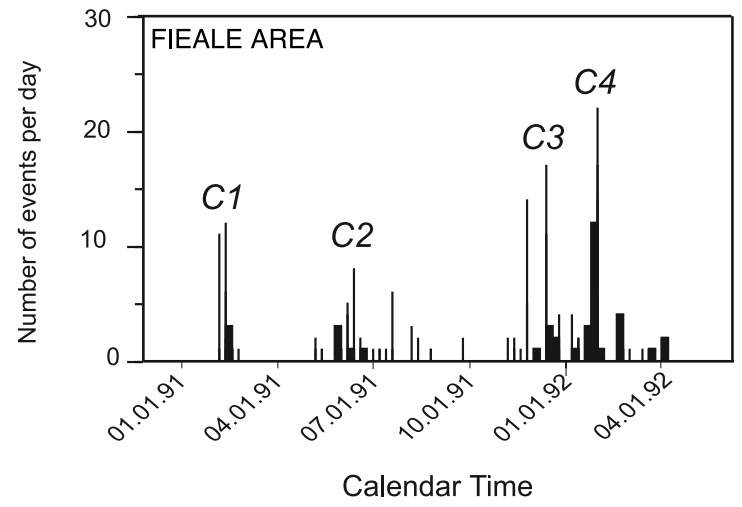

Figure 8. (continued)

curves in Figures $8 \mathrm{a}$ and $9 \mathrm{a})$. The Fieale area was by contrast relatively quiescent during this phase. Events in the northern shoulder mainly occurred from 1979 to 1982 when the Fieale area was entirely free of earthquakes $(\mathrm{Md} \geq$ 0.6 events; Figure 9b). The situation reversed at the beginning of 1983 , with seismic activity ceasing in the northern shoulder while starting in the Fieale-SB area with a few small-magnitude events.

[51] Figure S4 focuses on the temporal evolution of events between 1979 and 1982. On cross section P1, events form a $\sim 60^{\circ} \mathrm{SW}$ dipping cluster parallel to the $\varepsilon 1$ fault plane (section 4.2.2). Events occurred in successive short pulses (see clusters of distinct colors in Figure S4a) which initiated at the base of the $\varepsilon 1$ fault plane at $\sim 5-6 \mathrm{~km}$ depth, then migrated up to 4-3 km over 2 years (dark blue to green in Figure S4b), before migrating laterally southeastward along the plane in a few months in 1981 (Figure S4a, green to yellow). From 1983 to 1986, recorded events are too scarce to precisely describe their temporal evolution. Most epicenters are located at the base of the eastern Fieale caldera rim, between faults D and B.

\subsection{Phase 2 (1987-1995)}

[52] From about 1987 to the end of 1995, little seismic energy was released in the rift (Figure 8a). Activity was mainly restricted to the Fieale area and produced very small earthquakes (Figures 8a-8d, 9c, and 9d). This activity occurred through three major pulses $(\mathrm{p} 1, \mathrm{p} 2, \mathrm{p} 3$ in Figures $8 \mathrm{~b}$ and $8 \mathrm{c}$ ) separated by longer periods of low activity. Note, however, that the low density of the network from 1993 to 1995 prevents any recognition of activity in that time span.

[53] Figure S5 shows the temporal evolution of events during the 1987-1990 period and allows a better identification of the first pulses $\mathrm{p} 1$ and $\mathrm{p} 2$. Pulse $\mathrm{p} 1$ includes 41 events mostly concentrated at the base of the Fieale caldera eastern ring fault, between the D and B fault planes (about September 1987 to January 1988, violet-dark blue, $-0.5 \leq$ $\mathrm{Md} \leq 1.6$, total seismic moment of $6.41 \times 10^{11} \mathrm{~N} \mathrm{~m}$ ). That first pulse was immediately followed by a few events occurring outside of Fieale, in the DLM subrift and northern rift shoulder. No more earthquakes were recorded in the rift during the following 10 months. Activity then resumed from 13 February to 18 March 1989 (pulse p2, green in Figure S5) with the occurrence of 12 events, all in the Fieale area and most at the base of the eastern Fieale ring fault $\left(-0.4 \leq \mathrm{Md} \leq 0.0\right.$, total seismic moment of $\left.1.00 \times 10^{10} \mathrm{~N} \mathrm{~m}\right)$. Only two earthquakes were recorded during the following 2 years (until 4 February 1991). Activity then increased at the beginning of 1991, with 358 events recorded in the following year (pulse p3 from February 1991 to March 1992, Figures 8a, 8b, 8c, 9c, 9d, and S6; $-0.9 \leq \mathrm{Md} \leq 2.0$; total seismic moment of $\left.5.89 \times 10^{12} \mathrm{~N} \mathrm{~m}\right)$. Most events occurred in the eastern half of the Fieale caldera. Others were below the SB caldera, within the DLM subrift, NW of Fieale, and along the SE section of fault D. These events all surrounded the Fieale edifice (Figure S6a) and occurred in successive swarms (which we refer to as "crises" $C_{i}$ in the Fieale area) interrupted by short periods of relative quiescence (Figures 8e-8f). In Fieale, the crises lasted for a few months while they only lasted for a few days outside of Fieale. In general, any swarm outside of Fieale occurred immediately after one inside Fieale. The first Fieale crisis occurred between 4 February and 24 February 1991 (C1, Figure 8f; violet in Figure S6). It involved 49 events most at the base of the eastern Fieale ring fault, and a few others close to the $\mathrm{D}$ and $\mathrm{B}$ fault planes $(-0.7 \leq \mathrm{Md} \leq 1.3$; total seismic moment of $7.67 \times 10^{11} \mathrm{~N} \mathrm{~m}$ ). A few months later another crisis occurred (C2, Figure 8f; between 20 May and 8 July 1991, pale blue in Figure S6; $-0.5 \leq \mathrm{Md} \leq 1.5$ with

Figure 8. Temporal evolution of seismic moment release, number of events, and magnitudes over the 1979-2001 period, in subaerial section of AG Rift. (a) Temporal evolution of cumulative seismic moment release (solid line) and of cumulative number of events (dashed line) in the whole subaerial section of the rift. Events with Md $\geq 1$ are distinguished in grey. Opening rates of the rift inner floor deduced from geodetic measurements are indicated [Vigny et al., 2007]. (b) Temporal evolution of the daily number of events in the whole subaerial section of the rift. (c) Temporal evolution of the daily number of events in Fieale area. Pulse p3 of phase 2 is described in Figures 8e and 8f. (d) Temporal evolution of duration magnitudes for events in Fieale area. (e) Evolution of the daily number of events during pulse p3 of phase 2 (1991 - 1992 period), in whole rift subaerial section. (f) Evolution of the daily number of events during pulse p3 of phase 2 (1991-1992 period), in Fieale area. 

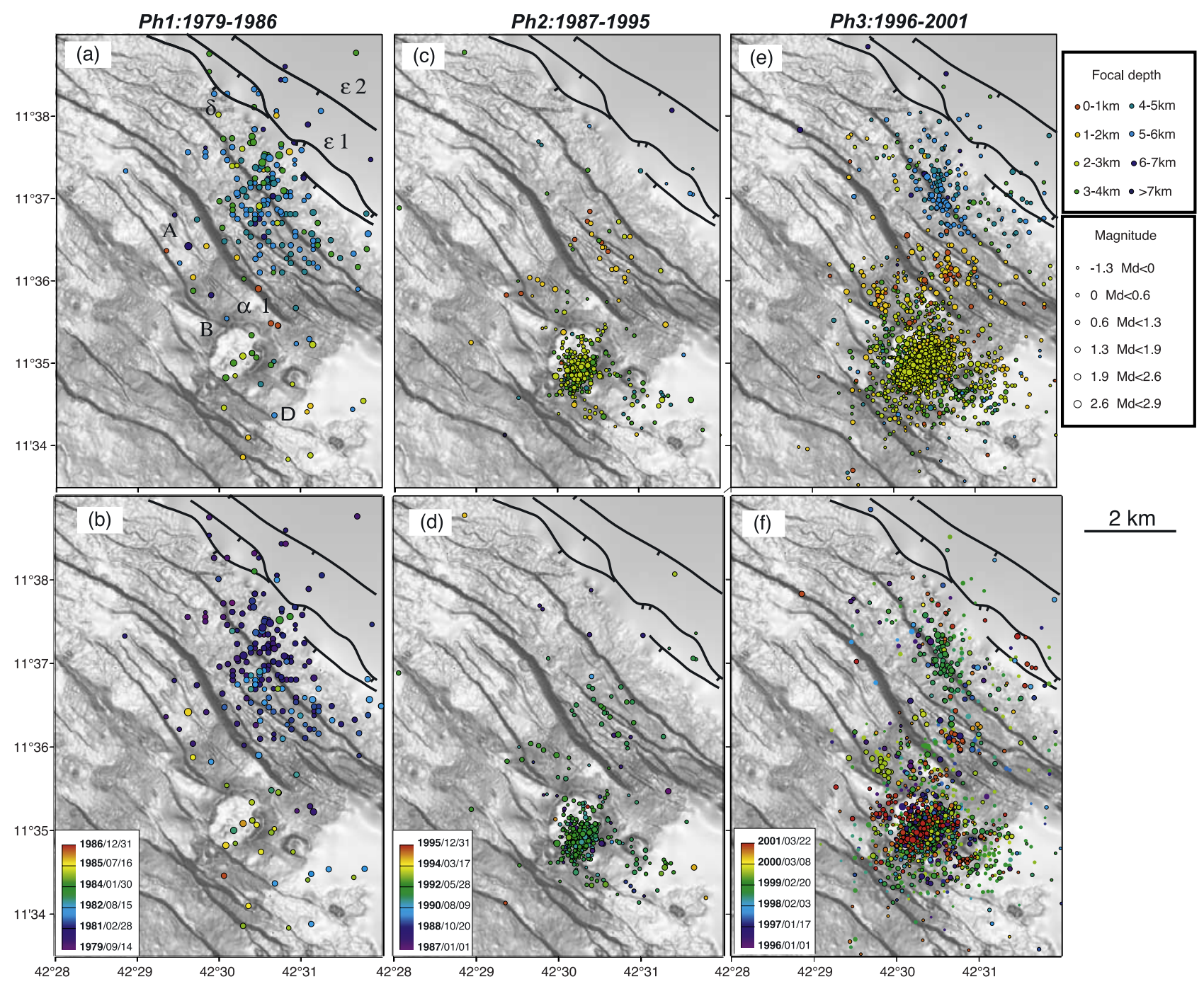

$2 \mathrm{~km}$

Figure 9. Event distribution during the three major phases identified. Colors in Figures 9a, 9c, and 9e indicate focal depths; colors in Figures 9b, 9d, and 9f indicate temporal evolution. (a-b) Phase 1, from 1979 to 1986. (c-d) Phase 2, from 1987 to 1995. (e-f) Phase 3, from 1996 to 2001 (and possibly more). Events relocated with 3-D crustal model are black circles in Figure 9f.

a total seismic moment of $8.83 \times 10^{11} \mathrm{~N} \mathrm{~m}$ ) with 45 events also produced mostly at the base of the eastern Fieale ring fault (with some possibly on D plane). This second crisis was immediately followed by two short swarms occurring more or less simultaneously (6 and 8 July 1991) outside of Fieale, in the SB area (9 events, mostly on eastern ring fault) and in DLM (9 events, Figure S6). Another short swarm followed 1 month later (8 August 1991) at an even larger distance from Fieale (below $\varepsilon 1$ fault trace, Figure S6). From 20 October 1991 to 12 December 1991, a third major crisis stroke Fieale producing 90 events mainly at the base of the eastern Fieale ring fault (C3, Figure 8f; $-0.4 \leq \mathrm{Md} \leq 1.7$; total seismic moment of $1.55 \times 10^{12} \mathrm{~N} \mathrm{~m}$; pale green in Figure S6). This crisis was immediately followed once again by a short swarm of 16 events between 4 and 27 December 1991 outside of Fieale to the NW, between faults B and $\alpha$ (Figure S6). Finally, another major crisis occurred a month later in Fieale with 72 microearthquakes
(C4, Figure 8f, 2-6 February 1992; $-0.9 \leq \mathrm{Md} \leq 2.0$; total seismic moment of $1.76 \times 10^{12} \mathrm{~N} \mathrm{~m}$; yellow in Figure S6). While the first events were again at the base of the eastern Fieale ring fault, the later spread west of that ring fault, within the caldera. Two short swarms occurring almost simultaneously in March 1992, outside of Fieale, in the SB caldera and in the DLM subrift (red, Figure S6) followed this last Fieale swarm.

[54] All the observations above show that the 1987-1995 period was dominated by significant seismic activity within the Fieale caldera, characterized by a few successive, month-long pulses or crises, separated by equally long or longer periods of relative quiescence. Most Fieale pulses/ crises are associated with deformation at the base of the eastern Fieale ring fault, between $\sim 2.5$ and $3.5 \mathrm{~km}$ depth and between faults D and B. The last crisis, however, shows more shallow ruptures $(2-3 \mathrm{~km}$ depth) that are more widely distributed within the thin volume of rocks at the roof of the 
central hot rock pipe. This suggests a lateral (from eastern to western Fieale ring faults) and upward migration of the "rupturing zone" at the end of 1991. Finally, most Fieale crises were immediately followed by swarms of events lasting one or a few days striking the areas immediately adjacent to the Fieale edifice (DLM subrift, SB area, and area NW of Fieale).

\subsection{Phase 3 (1996-2001)}

[55] From 1996 to the end of the 2001 experiment, the last third of the total energy was released through $\sim 1500$ events (Figure 8a), including $13 \%$ of the $M \geq 1.0$ events recorded during the whole period under study. The SE termination of fault A, DLM subrift, northern rift shoulder, the Fieale and its surrounding areas were the locus of dense seismicity (Figures 9e and 9f). The activity occurred during six successive pulses that lasted between a few months and 1 year and that were interrupted by similarly long periods of relative quiescence (Figures 8 and 10a, p1-p6). Figures 10a and $10 \mathrm{~b}$ show that each pulse occurred in the Fieale area and comprised alternating of high crisis and short peaks. This demonstrates that seismic activity was discontinuous even at shorter timescales of a few weeks to a few months.

[56] Auxiliary material Figures S7-S11 show the temporal evolution of events both in maps and cross sections for each calendar year since 1996, and help to examine the main characteristics of the six major pulses and of their major crises. These characteristics are reported in Table 2, while the temporal succession of crises and pulses is illustrated in Figure10c.

[57] Seismic activity over the 1996-2001 period occurred through the repetition of similar sequences, comprising the following features. All of them start with one or two crises within the Fieale caldera. These first crises generally initiate with a $\mathrm{Md}>1.0$ event located at the base of the eastern Fieale ring fault, at $\sim 3-4 \mathrm{~km}$ depth. Each crisis subsequently produces a large number of smallmagnitude events in a time span commonly shorter than a month. The total seismic moment released during each crisis averages $10^{12} \mathrm{~N} \mathrm{~m}$. Some events ultimately migrate northwestward away from the eastern ring fault. No event occurs west of the western Fieale ring fault nor outside the D-B graben. At the end of each Fieale crisis, one or two short swarms of events occur outside of Fieale and last less than a few days or weeks. The first swarm occurs in the immediate vicinity of the edifice (DLM, SB area; Table 2); the second one occurs a bit farther away (northern shoulder). Their total seismic moment is generally smaller than that released before in Fieale.

\section{Discussion}

[58] The detailed analysis of the spatiotemporal evolution of the seismicity that has occurred since the 1978 rifting episode, bring some insights to constrain both the transient processes that followed the rifting event and the 3-D crustal structure of the rift.

\subsection{Constraints on the Activity of the Main Volcanic Center}

[59] The main region of concentrated seismic activity between 1979 and 2001 underlies the Fieale and adjacent
$\mathrm{SB}$ and $\mathrm{f}$ calderas within the rift inner floor. Several observations support the inference that the main volcanic Fieale-SB center is active and responsible for a large part of the observed seismicity:

[60] 1. The tomographic analysis [Doubre et al., 2007] reveals that the Fieale-Shark Bay caldera zone is underlain by a central pipe of heated rocks, enclosed by an annulus of frozen intrusions. The pipe likely rises above a deeper magma chamber. The Fieale-SB deep structure is similar to that of other active volcanic systems worldwide [e.g., Arnott and Foulger, 1994a; Gudmundsson et al., 1994; Dawson et al., 1999; Miller and Smith, 1999].

[61] 2. Most of the seismic activity concentrates within a $4-6 \mathrm{~km}^{3}\left(\sim 1-1.5 \times 1.5 \times 2-2.5 \mathrm{~km}^{3}\right)$ volume of brittle material located at the roof of the central hot pipe, in between the faults, volcanic and tectonic, that bound the Fieale-SB volcanic system at depth. The seismicity is therefore related to that volcanic system. That most events cluster at the base of the faults suggests that the Fieale-SB events essentially result from slip on, or deformation around, the fault planes.

[62] 3. Activity in Fieale-SB is discontinuous, occurring through successive pulses separated by periods of relative quiescence. That behavior is typical of active volcanic systems [e.g., Brandsdottir and Einarsson, 1979; Einarsson and Brandsdottir, 1980; Bergman and Solomon, 1990; De Natale et al., 1995; Zollo et al., 2002].

[63] 4. The major Fieale crisis recorded in 2000-2001 significantly modified the stress field in the Fieale area (local increase of $\sigma 3$ ), such that the local stress tensor became close to isotropic [Doubre et al., 2007]. We take that perturbation as indicating a sudden pressure increase in the Fieale-SB hot rock pipe and possibly in the magma reservoir underneath. The focal mechanisms determined for events in this area [Doubre et al., 2007; Lépine and Hirn, 1992] confirm such a composite (i.e., volcano-tectonic) origin. We hypothesize that most crises that occurred before in the Fieale-SB area were of a similar type.

[64] 5. The "cascade-like" temporal evolution of earthquake swarms in the rift consisting of a series of small swarms that migrate laterally from the Fieale-SB volcanic center is obviously related to the activity of the Fieale volcanic system. Such an influence of the volcanic center on the surrounding seismicity has been observed in other volcanic environments [Crane et al., 1997; Sohn et al., 1998; Muller and Jokat, 2000; Tolstoy et al., 2001; Toda et al., 2002; Okubo and Nakata, 2003], and generally interpreted in terms of stress transfers [Pollard et al., 1983; Rubin, 1990; De Natale et al., 1995; Troise et al., 2003; Feuillet et al., 2004, 2006]. This further confirms that activity in the Fieale-SB volcanic center induces local modifications of the ambient stress field.

\subsection{Constraints on the Fault Activity}

[65] Geodetic measurements reveal that the AG Rift has sustained $\sim 50 \mathrm{~cm}$ of horizontal opening (along the NE direction) in the 1979-2001 period [Vigny et al., 2006a, 2007]. Our seismological data show that this opening was associated with a low level of seismicity. The whole population of events including those in Ghoubbet is hardly equivalent to a single 3.7 magnitude earthquake. This 


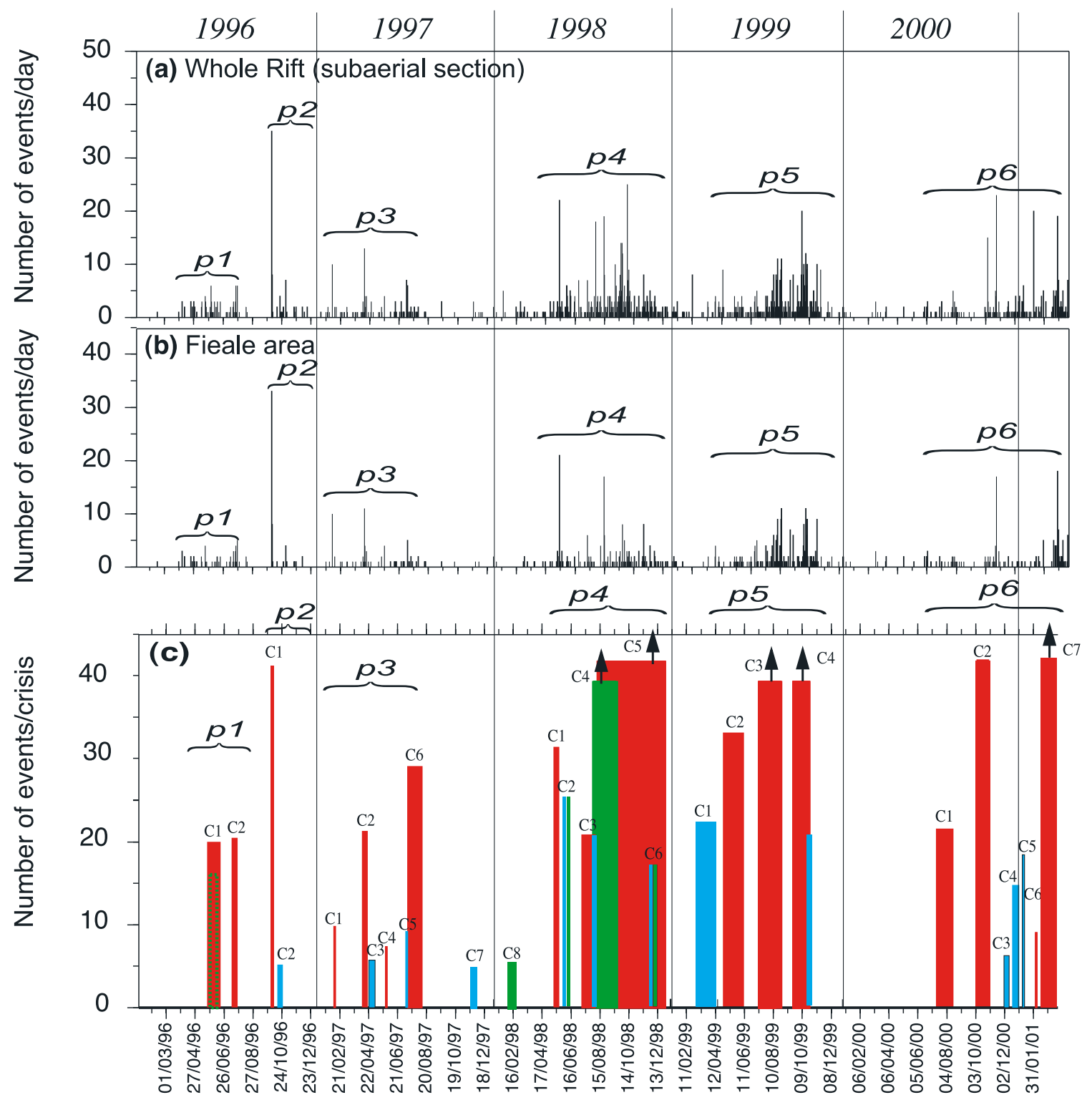

Calendar time

\section{Fieale area}

Immediate periphery of Fieale

\section{Zones more distant from Fieale}

Figure 10. Identification of major pulses and crises during phase 3 (1996-2001). (a) Histogram of daily number of events in subaerial section of the rift. Major pulses p1-p6 are identified. (b) Histogram of daily number of events in Fieale. Major pulses p1-p6 mainly occur in the Fieale area. (c) Temporal succession of major crises $\left(\mathrm{C}_{\mathrm{i}}\right)$ recognized in $\mathrm{p} 1-\mathrm{p} 6$ pulses. Details are in Table 2. Black arrows pointing upward are for event numbers greater than 40 . See text for discussion.

demonstrates that the postrifting opening process has essentially been aseismic.

[66] As said before, most recorded events are concentrated in the Fieale-Shark Bay area and result from activity of that volcanic center. We infer that most rift faults have either not slipped since 1978, or have creeped aseismically. Local geodetic measurements show that faults $\mathrm{D}$ and $\gamma 2$ did slip in the 23 years of study, at least at one local spot of their trace (Figure S1b-S1c, location in Figure 1b). In contrast, the leveling profile that crosses the rift is so tortuous, oblique and distant to most faults (Figure 1b) that interpreting the measured differential vertical motions (Figure S12) in terms of fault slip is difficult. A visual inspection of Figure S12 rather suggests that the total vertical offsets across the faults 


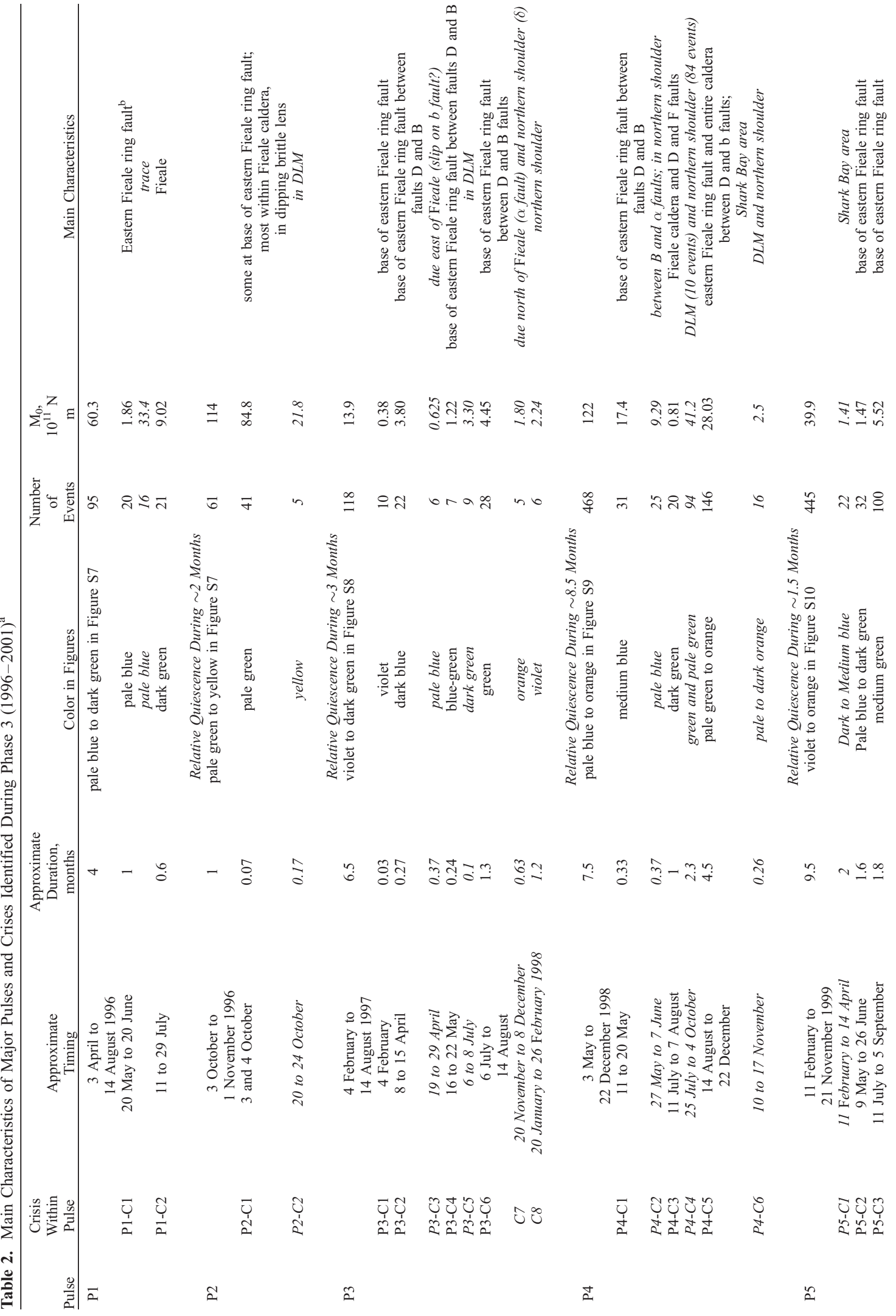


are small (except at $\gamma 2$ western tip where continuous slip is documented). The geodetic data thus do not discriminate whether or not faults have slipped in the 23 years of study. Our seismological data show that a few faults, namely F, D, $\mathrm{B}, \alpha, \gamma 1-2$ and $\varepsilon 1-2$, produced or were associated with microearthquakes, hence possibly slipped or deformed in the 1979-2001 period. Their slip, if any, was essentially aseismic for only microevents were produced. It also was only local for events are found at a few spots only of the fault planes.

[67] From our observations, the current tectonic activity can be more detailed:

[68] 1. Only the faults in the northern half of the rift have been active. The tectonic activity has thus remained mainly concentrated in this area since at least $30 \mathrm{ka}$ [Manighetti et al., 1998].

[69] 2. All faults have steep planes down to several $\mathrm{km}$. Their dips decrease from $\sim 90^{\circ}$ at the rift axis to $50-60^{\circ}$ in the oldest, outermost parts of the rift. Thus, while the faults bounding the inner floor accommodate its vertical subsidence, normal faulting farther from the rift axis accommodates a part of the horizontal extension.

[70] 3. No fault has slipped nor deformed on its entire surface. Instead, events cluster in narrow patches or volumes on or around the fault planes. All slip patches or volumes (except that in the NW associated to $\varepsilon 1$ ) extend in the vicinity of the Fieale caldera, within a $\sim 2.5-\mathrm{km}$-wide, $\sim 5-\mathrm{km}$-long, NE trending strip running from Fieale to $\varepsilon 2$ fault trace. Such distribution suggests that slip or deformation on the faults has primary occurred as a response to activity in Fieale.

[71] 4. The slip patches represent total surfaces $<1-2 \mathrm{~km}^{2}$ and total dissipated moments $<10^{12} \mathrm{~N} \mathrm{~m}$, hardly equivalent to $1 \mathrm{~mm}$ of slip on $100-\mathrm{m}$-long rupture zones. In most cases, microevents are distributed around the fault planes, preferentially at their base. This suggests that the clusters may result from off-fault, distributed "cracking", such as that induced by stress relaxation at fault edges [e.g., Scholz, 2002; Manighetti et al., 2004].

[72] 5. The 23-year lack of earthquakes below 3-4 km depth on the innermost faults (F, D, B, A, $\alpha, \gamma, \delta$ ), and below 5-6 km farther north $(\varepsilon)$, suggests that brittle ruptures are inhibited below these depths.

[73] We thus conclude that while some tectonic deformation has occurred over the 23 years of study, we ignore the exact behavior of faults during that period. A first hypothesis compatible with our observations is that most faults have not slipped at all; the recorded events would only attest to "microcracking" around their planes, likely induced by local stress relaxation. A second hypothesis also compatible with the observations is that some faults may have indeed slipped, yet essentially aseismically; the recorded events would attest to a distributed, small-scale deformation induced by the fault creep motion. Available data are presently unable to discriminate these two hypotheses. A recent InSAR analysis shows that a few rift faults (namely $\gamma 2, \beta$ and eastern tip of F) have creeped near the surface in the 1997-2005 period [Doubre and Peltzer, 2007]. The total slip accommodated over the 4 years common to both studies is small, however (from 0 to a few $\mathrm{mm}$ ), and detected only along short sections of the faults. 


\subsection{Rift Structure}

[74] Figure 11 synthesizes the along-strike and acrossstrike structures of the rift (subaerial section) that we propose based on our observations, our previous tomography results [Doubre et al., 2007], and the present knowledge of slow spreading segments worldwide.

[75] Similar to other rift/ridge segments [e.g., Saemundsson, 1978, 1979; Karson et al., 1987; Gudmundsson, 1998; Ebinger and Hayward, 1996; Parson et al., 2000], a main volcanic center, Fieale-SB, lies at the center of the AG inner floor. At the surface, the Fieale-SB complex forms a $\sim 3.5-\mathrm{km}$-diameter edifice, notched by the central, $\sim 2$-km-wide collapse Fieale caldera and the two adjacent smaller calderas SB and f. The western Fieale and eastern Shark Bay ring faults combine to enclose a subvertical, $\sim 2.5-\mathrm{km}$-wide conduit of hot rocks below the calderas. From earthquake distribution, we infer that temperatures in the hot pipe are less than $\sim 600^{\circ} \mathrm{C}$ above $\sim 4 \mathrm{~km}$, and higher than $600^{\circ} \mathrm{C}$ at greater depth. This is consistent with the temperature measurements performed in the nearby well A5 (Figure 11b) [Zan et al., 1990], which indicate $360^{\circ} \mathrm{C}$ at $\sim 2.1 \mathrm{~km}$ depth. Assuming a constant $\sim 170^{\circ} \mathrm{C} / \mathrm{km}$ gradient, a temperature of $600^{\circ} \mathrm{C}$ is inferred at $\sim 3.5 \mathrm{~km}$ depth, while temperatures of basaltic melt $\left(1100-1250^{\circ} \mathrm{C}\right)$ [e.g., Hess, 1992; Sinton and Detrick, 1992] are expected below 6-7 km depth. This is consistent with the fact that no melt was detected above $5 \mathrm{~km}$ [Doubre et al., 2007]. Thus, if a permanent reservoir exists that contains large amounts of melt, it must be at a depth greater than 6-7 km, likely below the central hot rock pipe (Figure 11a). This confirms that the AG Rift is similar to the oceanic slow spreading segments, for which little evidence of a permanent crustal magma chamber exists, while melts more likely focus at mantle depth [e.g., Detrick et al., 1990; Dunn et al., 2005]. This does not preclude, however, that transient reservoirs of small size may intermittently form within the AG crust, as suggested by Vigier et al. [1999]. We suggest that the structure of the AG central magmatic system above 5-7 km can be drawn as a volume of hot rocks or crystal mush, deforming plastically/aseismically (semibrittle field [e.g., Scholz, 2002]) and possibly containing pockets of partial melt small enough not to drop the seismic wave velocities. Below this volume, the magmatic reservoir may consist of a zone of partial melt $(<10-30 \%)$ or melt possibly distributed in sills such as it is observed for slow spreading segments [Nisbet and Fowler, 1978; Smith and Cann, 1992] (Figure 11a).

[76] The AG reservoir is thus overlain with a several kilometer thick pipe of heated rocks, in which rocks deform aseismically. It is likely that a similar, albeit probably thicker shell of heated rocks overlies the $\sim 1200^{\circ} \mathrm{C}$ isotherm throughout the whole rift. To infer the depth of that shell along the rift axis (Figure 11a), we follow Pollard et al. [1983] and use the width of the inner floor $(\sim 8.5 \mathrm{~km})$ as a guide to deduce the depth of the preferential dike injection underneath the rift. We find that that depth, taken to be at least that of the $600^{\circ} \mathrm{C}$ isotherm, cannot be less than $4-5 \mathrm{~km}$. This is in keeping with the occurrence of earthquakes down to $\sim 4 \mathrm{~km}$.

[77] The geometry of the magmatic system in the acrossstrike direction is less clear (Figure 11b). The thermal influence of the central magma system seems greater in the southern part of the rift. The low-velocity zone extends slightly below the southern rift shoulder while it does not north of the rift axis. The southern rift shoulder also has been site of important tectonic and magmatic activity in the past [Manighetti et al., 1998], while the northern rift shoulder shows no sign of active volcanism or hydrothermalism. Finally, the southern rift shoulder holds a reservoir of hot water $\left(260-300^{\circ} \mathrm{C}\right)$ at shallow depth $(1.4 \mathrm{~km}$ [Mlynarski and Zlotnicki, 2001; Zan et al., 1990; Abdallah, 1997]). If the temperature gradient remains as high at greater depths, temperatures of $600^{\circ} \mathrm{C}$ and $1200^{\circ} \mathrm{C}$ could be reached before $\sim 4$ and 6-7 km depth, respectively. On the contrary, earthquake distribution in the northern rift shoulder indicates that the $600^{\circ} \mathrm{C}$ isotherm may be at $\sim 7 \mathrm{~km}$ depth, while the $1200^{\circ} \mathrm{C}$ isotherm would be below $12 \mathrm{~km}$. The crustal structure of the rift would thus be asymmetric, with a thinner crust in its southern half (Figure 11b). Overall, the crust thicknesses that we infer are consistent with those determined from seismic profiles in AG [Ruegg, 1975] and from the elastic modeling of the 1978 surface deformation [Tarantola et al., 1980]. This suggests that the AG crust is actually hardly thinner than the "normal" crust in the rest of Afar [Ruegg, 1975; Makris and Ginzburg, 1987].

[78] The crustal production is focused in the center of the rift, likely resulting from melt migration from a mantle diapir, as observed in slow spreading ridges [e.g., Lin et al., 1990; Detrick et al., 1995; Wolfe et al., 1995; Cannat, 1996; Allen et al., 2002; Dunn et al., 2005]. We propose that the crustal spreading results from the lateral migration of magma in the shallow crust along rift-parallel dikes [e.g., Cann, 1974; Walker, 1999; Segall et al., 2001]. Because the recent lavas $(<50 \mathrm{ka})$ are confined within the rift inner floor (Figure 1b), we suspect that the density of dikes and the extension accommodated by this magmatic dilatation are higher in the central part of the rift, as observed in ancient and eroded rift segments [e.g., Speight et al., 1982; Helgason and Zentilli, 1985]. The recent lava fields extend on either side of the Fieale-SB topographic edifice, while the FiealeSB calderas are free of young lavas (but those erupted from $\mathrm{f}$, where it is offset by fault D). Faults $\mathrm{D}$ and $\mathrm{B}$ meet westward to end in the axial volcanic chain that forms a natural extension of the fault planes; it is as if their deep sections are conducts for magma to circulate laterally from the rift center throughout the inner floor. This is consistent with the fact that fault $\mathrm{D}$ ends to the east as a large open fissure from which lavas are erupted. Similarly, lavas flows and small volcanic cones clearly poured out from the eastern and western terminations of fault $\mathrm{F}$ and many smaller faults within the rift inner floor. Finally, the 1978 Ardoukoba lavas flowed at the very western tip of the axial volcanic chain. Together these show that recent magmas have migrated laterally, both southeastward and northwestward, within the rift inner floor, and erupted quite far from the central Fieale-SB volcanic source. Note that the surface trace of fault $\alpha$ is free of recent volcanics, suggesting that fault $\alpha$ did not convey any magma in recent times. From all this we infer that the active feeding dike system where magmas are presently upwelling from the mantle reservoir, is confined within the 2- to 3-km-wide zone enclosed between the faults F and B (Figure 11b). We suggest that magmas (under "reasonable" pressure conditions) cannot directly rise up along the Fieale-SB ring faults 
(a)
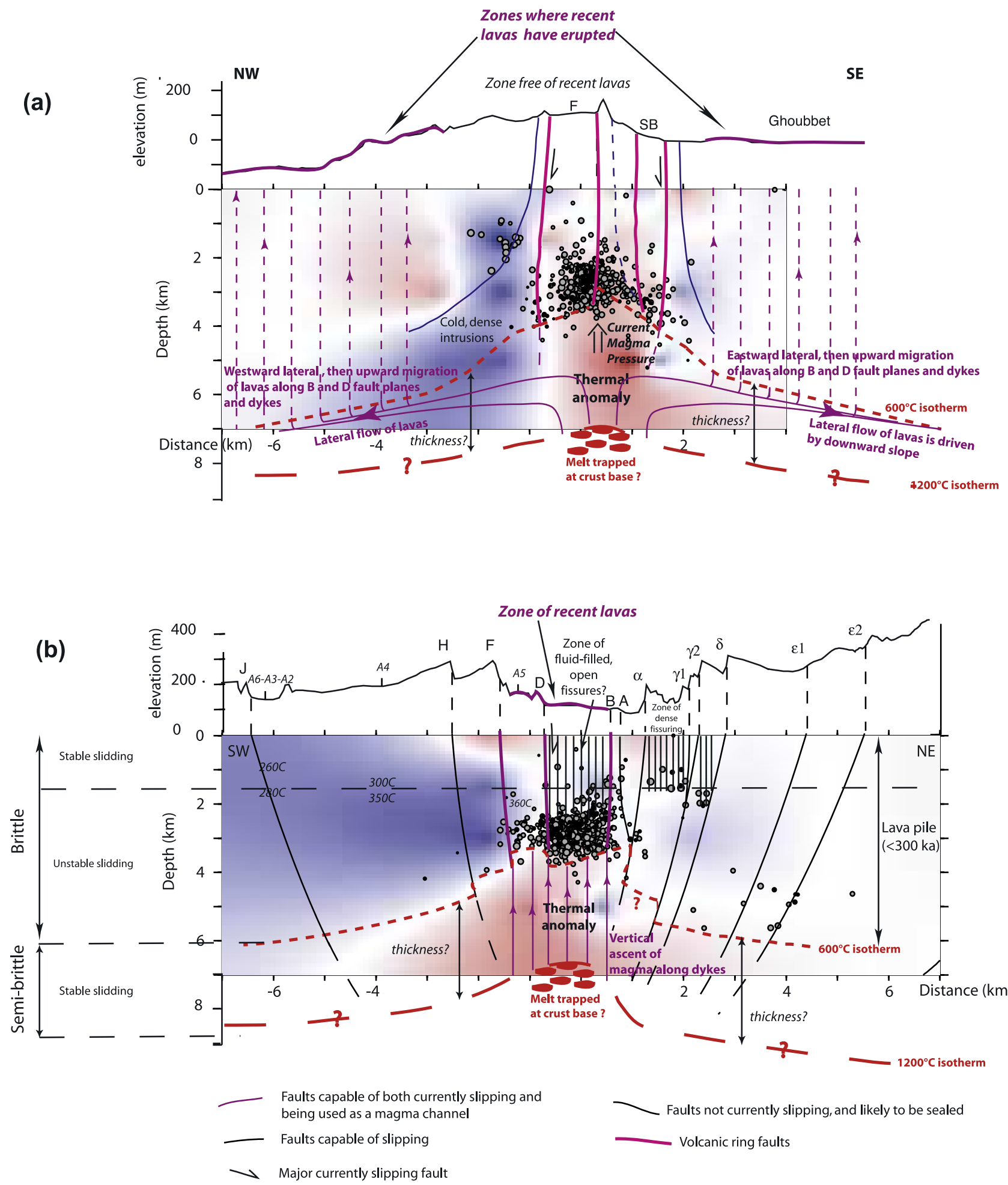

Figure 11. AG Rift crustal structure (subaerial section) in best agreement with all observations. Cross sections are Ax and P3 of Figure 5a. P wave velocity anomalies are from Doubre et al. [2007]. For clarity, only best constrained events are plotted (1996-2001). Names of faults and volcanic features are as before. $A_{\mathrm{i}}$ indicates position of drilled wells, with measured temperatures indicated [see Abdallah, 1997]. See text for discussion. 
because the volume of material that caps the Fieale-SB conduit acts as a plug that impedes their vertical ascent. The weight of the Fieale topographic edifice may also impede lava ascent [Pinel and Jaupart, 2000; Muller et al., 2001]. The "light", viscous liquids and crystal mush rich in plagioclases [see Joron et al., 1980; Bizouard et al., 1980] that may arise first from the original melts may be those most arrested by the capping plug. By contrast, the denser, less viscous basaltic liquids may more easily escape laterally, away from the reservoir and overlaying plug [Walker, 1999, and references therein]. They would propagate along the existing dikes and faults, possibly at the base of the brittle crust and/or within the shell of hot rocks (where faults and dikes root, Figure 11a). Where the confining pressure would allow it (as outside the zone overloaded by the weight of the topographic Fieale-SB edifice), they would eventually ascend vertically. Most dikes do not reach the surface, however, but rather end in the shallow crust through the development of dense networks of open "dry" fissures [Manighetti et al., 1998]. Note that similar lateral migrations of lavas have been documented in other active and extinct rift segments or basaltic systems [e.g., Knight and Walker, 1988; Moreira et al., 1999; Dziak and Fox, 1999; Embley et al., 2000; Herrero-Bervera et al., 2001; Callot et al., 2001], while the use of fault planes for magma transport has been observed in Iceland [Gudmundsson and Loetveit, 2005].

[79] Finally, except for in the DLM subrift, we note that the lack of earthquakes at shallow depths $(<1.5-2 \mathrm{~km}$; Figure 11) is consistent with the laboratory observation of stable sliding at low confining pressures [e.g., Scholz, 1988; Cowie et al., 1993; Marone, 1998]. That most earthquakes cluster at the roof of the semibrittle shell zone suggests that those events result from stress relaxation. Stress concentrations are indeed high in the shallowest part of this transition zone, as stable slip within the zone loads the overlying brittle crust [e.g., Tse and Rice, 1986; Scholz, 1988]. Most events thus likely are small ruptures aiming at relaxing the stresses accumulated at the base of the faults [Barclay et al., 2001, Meissner and Strehlau, 1982; Sibson, 1982, 1984]. This further suggests that most rift faults have not significantly slipped in the last 23 years.

\subsection{Rift Behavior Since 1978}

\subsubsection{November 1978: Corifting Phase}

[80] We have described the 1978 rifting episode in section 2. A few additional points need, however, to be noted.

[81] First, no previous rifting event or major earthquake has been reported in the rift before the 1978 episode [Gouin, 1979; Audin et al., 1990; Jacques, 1995]. Together with the fact that several large earthquakes occurred during the 1978 event, this suggests that the rift was highly stressed when the rifting crisis occurred. The stress regime prevailing in the rift thus likely was a strong deviatoric tension of the type $\sigma 3 \ll \sigma 2<\sigma 1$.

[82] The 1978 rifting event was mainly a diking episode. Only faults above or adjacent to the intruded zone slipped, and by small amounts $(1-10 \mathrm{~cm}$ on a few faults). Faults thus did not relax much of the tensile stresses that they had accumulated before (unless they had been creeping before 1978, a possibility that we ignore).
[83] The 1978 dike opening induced a significant coeval contraction in the northern rift shoulder, particularly in Ghoubbet [Ruegg et al., 1979; Tarantola et al., 1979]. This shows that the dike opening was driven by a magma pressure higher than the tensile stresses accumulated in the crust. Thus the AG Rift did not "passively" open to relax the stresses accumulated over the interrifting period. Instead, it opened through an active, magmatically driven process. The pressure in the dikes added and transferred compressive stresses to the shallow crust, large enough to reset the stress field at some places to near isostatic $(\sigma 3 \sim$ $\sigma 2 \sim \sigma 1$ ) or even deviatoric compression (see Arnott and Foulger [1994b] for similar observations in Iceland). Thus, at the end of the 1978 episode, the "reset" places were left relaxed of their accumulated deviatoric stresses. This does not preclude the possibility that some faults or fault sections remained loaded.

\subsubsection{The 1979-1986 Phase: First Phase of Postrifting} Response

[84] The rift continued opening 3-4 times faster than the plate spreading rate in the $\sim 8$ years that followed the 1978 diking episode [Ruegg and Kasser, 1987]. The opening was focused in the rift inner floor, and amounted to a total of $\sim 35 \mathrm{~cm}$ of horizontal stretching (at the location of Fieale, Figure S1a). While opening, the rift sustained a general doming centered in the Fieale area, and the subsidence of its inner floor [Ruegg and Kasser, 1987; Ruegg et al., 1987; Kasser et al., 1987]. Similar deformation patterns and fast opening rates have been observed in Icelandic segments in the few years that followed their sudden opening [Heki et al., 1993; Jahn et al., 1994, Hofton and Foulger, 1996a]. In most cases, the fast opening and slip rates could be accounted for satisfactorily by using a viscoelastic Earth structure [e.g., Hofton and Foulger, 1996a, 1996b; Sigmundsson et al., 1997]. Yet, in the case of the AG Rift, the sudden drop in opening rate observed at the end of 1986 (Figure S1a) demonstrates that an additional process contributed to the transient postrifting deformation. The thermomechanical modeling of Cattin et al. [2005] suggests that a constant $\sim 12 \mathrm{~cm} / \mathrm{yr}$ inflation of the dike(s) at depth is necessary to explain the observed deformation. Such continued opening of a buried dike is in keeping with the measurement of a persisting small contraction in the northern rift shoulder, particularly between faults $\delta$ and $\varepsilon[R u e g g$ and Kasser, 1987].

[85] As shown in section 5.1, the immediate postrifting period is clearly distinguishable in the recorded seismicity. However, the total seismic moment dissipated during this phase 1 is low $\left(\sim 1.25 \times 10^{14} \mathrm{~N} \mathrm{~m}\right)$, unable to account alone for the $35 \mathrm{~cm}$ of inner rift opening. This demonstrates that the rift opening occurred aseismically in the immediate postrifting period. Rubin and Gillard [1998] showed that under small deviatoric stresses $(\sigma 3 \sim \sigma 2 \sim \sigma 1)$, as was the case of AG Rift in its immediate postrifting period, dikes can grow and propagate without producing any earthquakes.

[86] Between 1979 and 1982, the seismic activity affected the northern rift shoulder, while the geodetic measurements do not reveal any clear slip on the northern rift faults, except at the western tip of fault $\gamma 2$, during that time period. Since the recorded events are located approximately where a contraction has been measured [Ruegg and Kasser, 1987], we suggest that most 1979-1982 earthquakes result from 
ongoing contraction in this zone; microruptures would occur to relax the compressive stresses transferred from the ongoing dike opening onto the northern fault planes (Rubin and Pollard [1988], Rubin [1992], Toda et al. [2002], Sohn et al. [1998], and Feuillet et al. [2004] present similar observations from other locations). Moreover, most events cluster at the base of the planes where transferred compressive stresses are expected to be higher, just as they are at the depth of the pressurized dikes (Figure 11). We conclude that most earthquakes recorded between 1979 and 1982 occurred as a far-field effect of the 1978 diking event. Apart from this effect, the rift remained essentially quiescent for the entire 1979-1986 period. The slip measured on fault D during that time span (Figure S1b) thus essentially occurred aseismically.

\subsubsection{The 1987-2001 Phase: Second Phase of Postrifting Response}

[87] The opening rate of the rift inner floor dropped from $\sim 60$ to $15 \mathrm{~mm} / \mathrm{yr}$ at the end of 1986 , contemporaneously with the drop of the vertical slip rates on faults $\mathrm{D}$ and $\gamma 2$ (Figures S1b and S1c). These abrupt rate decreases show a clear change in the rift behavior. Since then, the rift continued opening at a constant rate, decreasing westward, however, from $\sim 17 \mathrm{~mm} / \mathrm{yr}$ in Ghoubbet to $\sim 15 \mathrm{~mm} / \mathrm{yr}$ in Fieale area and $\sim 6 \mathrm{~mm} / \mathrm{yr}$ at the western rift tip [Vigny et al., 2007], while the far field plate motion was slow, $11 \mathrm{~mm} / \mathrm{yr}$ [Vigny et al., 2006a, 2007]. A broad doming also occurred, centered over the northern rift shoulder [Vigny et al., 2007; Ballu et al., 2003], while the rift inner floor kept subsiding at $\sim 4.5 \mathrm{~mm} / \mathrm{yr}$ between faults $\mathrm{D}$ and $\mathrm{B}$. The total seismic moment dissipated in phases 2 and 3 is much too low $\left(\sim 5.10^{13} \mathrm{~N} \mathrm{~m}\right)$ for seismic deformation to account for the total $15 \mathrm{~cm}$ of rift opening during that period. This demonstrates that the rift kept opening aseismically in the 19872001 postrifting period, with that opening focused in its inner floor.

[88] Cattin et al. [2005] attribute the dramatic change observed at the end of 1986 to the complete cessation of the dike opening. Cattin et al. model the post-1987 geodetic measurements by combining stress relaxation induced by the dike inflation during the previous 1978-1986 period and aseismic creep on some faults (particularly $\gamma$ ). They show that the corifting stress relaxation is completed in a few years and that the viscous stress relaxation alone cannot account for the fast rift opening since 1987. Cattin et al. [2005] conclude that tectonic forces must have been rebuilding in the rift since 1987, inducing horizontal stretching and fault creep, so that the rift has entered its interrifting period. Yet a question remains; why is the rift still opening as fast as the plate driving motion, and even faster, more than 15 years after complete cessation of dike inflation? The rift is not expected to open so fast and continuously in its interrifting period. If it did, large deviatoric stresses would never accumulate so that large earthquakes such as those recorded in 1978 would never occur. We therefore suggest that the deformation observed in the 1987-2001 period (and even later) still attests to a transient postrifting behavior of the AG segment; the rift has not yet entered its steady state, interrifting period. Because our temporal analysis of events reveals an increase of activity in the Fieale-SB area since about 1988, and essentially since 1996, we suggest that the Fieale-SB magmatic system kept playing a signif- icant role in the overall post-1987 rift behavior. We envision the processes as follows. We attribute the sudden change at the end of 1986 to the sudden deflation of the magma reservoir underneath the rift. That deflation induced high tensile stresses in the crust above the Fieale-SB reservoir [e.g., Pollard et al., 1983; Doubre and Geoffroy, 2003]. Subjected to the regional extension, the rift would thus stretch preferentially in that zone. The Fieale-SB area forming a weak spot from the mechanical/rheological points of view (high thermal gradient, great density of open fissures), the stretching would essentially occur through the aseismic opening of fissures and creep on innermost faults. Stretching of the rift inner floor would induce a pressure decrease in the underlying Fieale-SB conduit. The pressure decrease would in turn favor buoyant magma to travel upward and fill the numerous faults, open fissures and dikes that offset the inner floor. Lavas would not reach the surface, however. The magma pressure would consequently rebuild in the hot Fieale-SB conduit, till a subsequent "breakage" (mainly in the form of aseismic opening) of the zone lowers it again. Also, the process would repeat. We therefore see the seismic crises that have affected the FiealeSB area since 1988 as the evidence for repeating piston-like motions above the Fieale reservoir. The stretching, pressuredecreasing episodes would coincide with the identified periods of seismic quiescence. Their duration would depend on the magma supply; they would last longer when little magma is available in the reservoir (as is the case in the few years following the 1986 deflation), and shorter when the reservoir is replenished. The inflating episodes would instead coincide with the various pulses and crises that have affected Fieale-SB since 1988. These inflating episodes would cause the volume that caps the hot conduit to slip upward principally along the eastern Fieale ring fault and the B fault plane (Figure 11). These motions would explain the tent shape of this volume.

[89] Thus, while the plate driving-induced stresses have certainly been rebuilding in the rift since 1987, most have been accommodated and relaxed within the rift inner floor, in the axial Fieale-SB magmatic zone. This suggests that most rift faults but those bounding the inner floor, have neither accumulated nor relaxed much stresses in the 19872001 period. More, each inflating episode in Fieale-SB may have, by modifying the local stress regime, contributed to inhibit or help slip on the faults or fault sections adjacent to the axial magmatic zone. The earthquake swarms that are observed to "cascade" away from Fieale support that hypothesis. The small intermittent creep events detected by Doubre and Peltzer [2007] on short fault sections nearby Fieale are also in keeping with that hypothesis. Together these suggest that 23 years after the 1978 rifting episode, most of the AG faults except some of those adjacent to Fieale, are still essentially relaxed and locked. The recrudescence of the seismic pulses and crises in Fieale-SB since 1996, together with the progressive shallowing of the brittle volume above the hot rock pipe, suggest that the magma pressure is currently rebuilding in the Fieale-SB reservoir.

\subsubsection{Completion of a Rifting Cycle}

[90] On the basis of the analysis above, we envision a complete rifting cycle in AG Rift as follows. Rifting events similar to that observed in 1978 would essentially be triggered by a sudden increase of magmatic pressure in 
the Fieale-SB central volcanic complex. The rapid filling of the reservoir, and/or the partial crystallization of magma in that reservoir and the resulting production of gas, could generate such a pressure increase. The pressure would be large enough for magma-filled dikes to fracture the crust (or for magma to flow within preexisting dikes and faults) and propagate laterally away from the Fieale-SB source within the rift inner floor. Rifting would therefore be "active" (according to the definition of Sengor and Burke [1979] and Turcotte and Emerman [1983]) in its very first stage, although the dike injection may be helped by extensive tectonic deviatoric stress accumulated in the rift by the continuous far field plate motion. Only faults above or adjacent to the diking zone would slip as a mechanical response to the dike opening at depth [Pollard et al., 1983; Rubin, 1990, 1992; Rubin and Pollard, 1988]. Slip on inner faults would occur mainly aseismically, and would make the rift inner floor generally subside. The opening of dikes increases the horizontal stress normal to the rift axis and to the dikes. The stress regime in the rift would thus become isostatic ( $\sigma 1 \sim \sigma 2 \sim \sigma 3)$, or slightly compressive at the end of the rifting episode. A number of rift faults would consequently be relaxed at the end of such an episode.

[91] During the following 7-8 years, the active diking process would continue steadily as an aseismic process. Although the magma flux may be the same as before, the pressure in the dike zone would be lower for that zone has already opened. The ongoing diking process would thus still add compressive stresses to the crust, but of smaller magnitude. The magma influx would also induce an overall doming of the rift, centered in the source zone (Fieale).

[92] After that period, and for unknown reasons, the magma influx would abruptly drop down. With no more active source, the rifting process would become "passive". The sudden deflation of the reservoir would induce high tensile stresses in the overlying crust. While the ongoing plate drift would subsequently rebuild the deviatoric extensional stresses throughout the rift, those accumulating above and around the mechanically weak magma chamber would be maxima, making the Fieale area always closer to failure than any other places in the rift. A balance between tectonic failure in the Fieale-SB axial zone (that drops down pressure), and magma influx from the Fieale-SB reservoir (that rebuilds pressure), would make the rift appear as $\sim$ continuously opening. Such a balance is observed to last for at least 15 years, and be particularly operating since 1996. We suggest that the opening mode observed since 1987 still is a transient response to the 1978 rifting episode. The AG Rift would not be yet in its so-called "interrifting period", but still in a postrifting, unsteady phase.

[93] That the 1978 rifting episode was accompanied with large earthquakes demonstrates that the AG Rift can store large deviatoric stresses and strain, and eventually relax them through brittle faulting. We thus hypothesize that there will be a time when the rift stops opening or slows so that its faults resume accumulating stresses. This time, which will mark the onset of the proper interrifting period, may initiate when the Fieale-SB reservoir is either completely empty with no more fresh magma capable of upwelling from the mantle, or frozen. From that time on, the rift faults will resume accumulating the plate-driven deviatoric stresses. From nearly isotropic in the postrifting period (at least the
23 years that we have analyzed), the stress regime in the rift will become strongly extensional in the interrifting phase, of the type $\sigma 3 \ll \sigma 2<\sigma$ lor $\sigma 3 \ll \sigma 2 \sim \sigma 1$ (see Arnott and Foulger [1994b] for similar observations in Iceland). We expect that another rifting episode will occur in the future to relax these stresses. It could be either a magmatic episode as the one in 1978 that would "indirectly" relax the loaded faults, or a tectonic episode that would "directly" relax the loaded faults. Stein et al. [1991] have proposed, from independent data, that the AG Rift must open through two distinct types of rifting episodes, one should produce basaltic eruptions and a few seismic events in the rift inner floor only, while the other one should see the outer rift faults seismically breaking in the absence of any volcanic activity. One phase or another would occur every 100-150 years. Although we cannot predict which type the next rifting episode in AG will be, we note that tectonic rifting events must have occurred in recent times, for the AG Rift exhibit impressive, sharp normal fault escarpments, some as high as $200 \mathrm{~m}$. The maximum thickness of the brittle crust being 3$4 \mathrm{~km}$ at the rift axis and $6 \mathrm{~km}$ in the rift shoulders, we expect that earthquakes as large as $\mathrm{M}=5.4-5.8$ may occur in the rift, producing at most a few tens of $\mathrm{cm}$ of vertical displacement, and about half of horizontal stretching.

\subsection{Evolution of Rifting in the Last $900 \mathrm{ka}$}

[94] Extrapolating backward in time from these observations, we can determine the main stages that the AG Rift went through over its $\sim 900 \mathrm{ka}$ total evolution. The two major assumptions that we make are as follows: (1) the source of magmatic production kept stable in the Fieale-SB area over its entire evolution and (2) the magma production rate has controlled the rift opening mechanism.

[95] There have been phases when magmatic production was high in the rift (building of thick piles of fissural "Gulf basalts" between $\sim 900$ and $400 \mathrm{ka}$; formation of Fieale edifice between $\sim 300$ and $100 \mathrm{ka}$; spreading of broad lava fields on either sides of Fieale edifice a few $10 \mathrm{ka}$ ago; eruption of Ardoukoba in 1978 [e.g., Manighetti et al., 1998]) interrupted by phases with low magmatic production (no surface manifestations). We hypothesize that during phases of high magmatic production, the rift opening process was "active", i.e., magmatically driven. It was also magmatically accommodated, with extension occurring by magmatic dilatation in the inner floor. In contrast, during phases of low magmatic production, the rift opening process was "passive", i.e., tectonically driven and accommodated; the rift extension occurred by normal faulting and fissuring on planes that had initiated above the central Fieale-SB magmatic source as a result of the tensile stresses induced by its previous depletion [Gudmundsson, 1986; Doubre and Geoffroy, 2003; Garel et al., 2002]. The faults would subsequently migrate outward as a result of the rift opening. Doing so, their planes would rotate from vertical above the reservoir to inward dipping away from it.

[96] Figure 12 sketches the overall evolution that we propose at the location of Fieale. The alternation of "magmatic" and "tectonic" phases, as suggested previously [Stein et al., 1991; Manighetti, 1993; De Chabalier and Avouac, 1994; Manighetti et al., 1998], was irregular in time, while the magmatic and tectonic contributions varied in intensity. It seems that the magmatic production was 


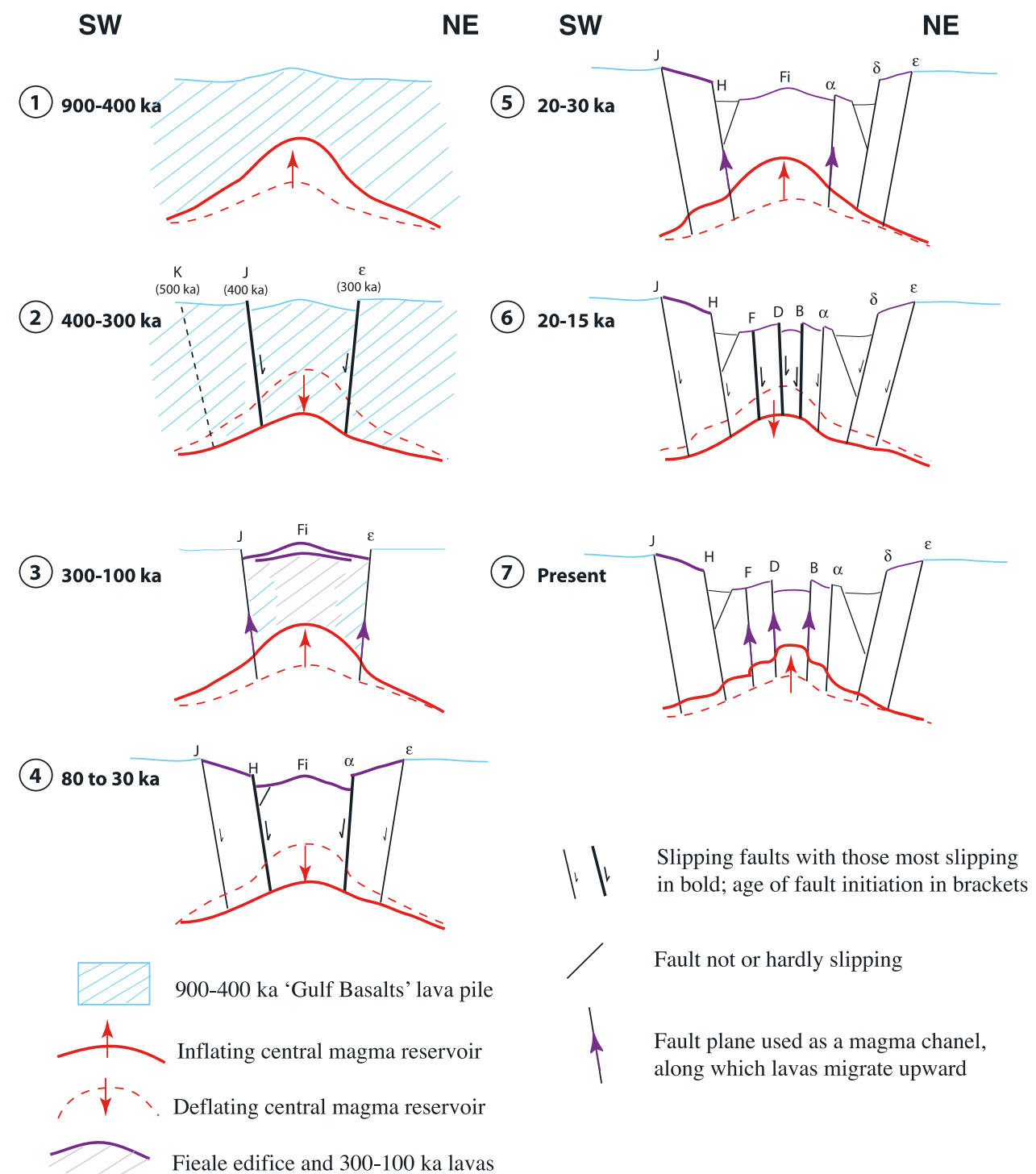

Figure 12. Envisioned evolution of AG Rift (at the location of Fieale) since $900 \mathrm{ka}$. The cross sections are modified from Figure 5 of Manighetti et al. [1998] to include our new results. Phases 1, huge magmatic activity leading to eruption of Gulf basalts; 2, magmatic starvation leading to formation of faults $\mathrm{J}$ and $\varepsilon ; 3$, intense magmatic activity leading to formation of Fieale (Fi); 4, magmatic starvation leading to formation of faults $\mathrm{H}$ and $\alpha ; 5$, significant magmatic activity leading to emplacement of lava fields on either sides of Fieale; 6, magmatic starvation leading to formation of faults F, D, and B; 7, minor magmatic activity leading to formation of Ardoukoba.

extremely high in the first $400-500 \mathrm{ka}$ of the rift history, leading to the building of the thick pile of fissural "Gulf basalts". No faults are known to have formed between 900 and $500 \mathrm{ka}$. Magmatic production may have started to decrease around $500 \mathrm{ka}$ to become low at $300 \mathrm{ka}$. Faults $\mathrm{K}, \mathrm{J}$ and $\varepsilon$ are dated at $\sim 500,400$ and $300 \mathrm{ka}$, respectively, which suggests that they may have formed in a northward succession resulting from the progressive depletion of the magma reservoir during that time span. Magmatic production increased again at $300 \mathrm{ka}$ and went on for $\sim 200 \mathrm{ka}$, leading to the formation of the broad topographic Fieale edifice between faults $\mathrm{J}$ and $\varepsilon$. The youngest Fieale surface flows are dated at $80 \mathrm{ka}$, suggesting that the magma reservoir started to deflate at that time. Faults $\mathrm{H}$ and $\alpha$ formed in a northward succession in the following $50 \mathrm{ka}$. That their surface traces curve toward the rift axis at the location of Fieale suggests that these two faults initiated in the Fieale area with subvertical planes [Van Wyk de Vries and Merle, 1996; De Chabalier and Avouac, 1994]. Magmatic activity must have increased again around 30-20 ka because broad lava fields spread on either side of the Fieale edifice. The small volcanic cones that underline the traces of faults $\mathrm{H}$ and $\alpha$ [see Doubre et al., 2007, Figure 2a] likely formed at that time, as both faults were used as conduits to convey magma at depth away from the Fieale-SB source. Magmatic activity then decreased again $20-15 \mathrm{ka}$ ago, 
leading to the formation of faults F, D and B above the depleting reservoir (fault $\mathrm{B}$ is dated at $\sim 15 \mathrm{ka}$ [Pinzuti et al., 2001]). From morphological observations, the F scarp looks older than those of faults D and B, indicating that these faults may again have formed in northward succession. The magmatic production may be presently increasing again, as suggested by the 1978 Ardoukoba eruption and the upward migration of the cluster of seismicity below Fieale-SB.

[97] Overall, magmatic production therefore seems to have decreased over time: It was significant and lasted for 400-500 ka at the onset of the rifting process, still important yet shorter during the Fieale formation when it lasted for $\sim 200 \mathrm{ka}$, even less important and shorter at 20-30 ka (emplacement of broad but thin lateral lava fields), and almost insignificant at present. Such variations on the magma production are in agreement with the existence of a tectono-magmatic cycle of several thousand years as observed along the Mid-Atlantic Ridge [Parson et al., 1993; Peirce et al., 2005]. That cycle would be related to the episodic presence of a crustal magma reservoir [Sinha et al., 1998; McGregor et al., 1998; Navin et al., 1998]. We suggest that a crustal magma chamber may have existed below Fieale $\sim 300$ to $100 \mathrm{ka}$ ago, and be responsible for the significant magma production at that time. In contrast, the current absence of a crustal reservoir suggests that the present behavior of the rift is controlled by a low magma budget; the Afar hot spot [e.g., Courtillot et al., 1999] thus has no influence on the magma production rate of the rift.

\section{Conclusions}

[98] Through the two companion papers, we have attempted to bring new insights into the understanding of the magmato-tectonic rifting process. Here, we have analyzed the 2500 small magnitude events $(\mathrm{Md} \leq 2.8)$ that have been recorded and located in the Asal-Ghoubbet Rift over the 1979-2001 period that followed its 1978 rifting episode. This dense data set allows event nature, distribution and temporal evolution to be examined in great detail, and discussed in the light of other available data, such as tomographic results [Doubre et al., 2007] and geodetic measurements. Our major findings are the following:

[99] 1. The crustal structure of the AG Rift is similar to that of slow spreading ridge segments. A main volcanic plumbing system, Fieale-Shark Bay, is located at the center of the rift and corresponds to the focused zone of crustal production. From the seismic velocities, no melt reservoir is observable at crustal depth. The magma production thus likely occurs at a deeper level, i.e., mantle depth, and/or by episodic replenishment in a temporary crustal reservoir. Structural evidence suggests that the crustal spreading is accommodated by lateral magma migration from the main volcanic center along dikes and faults below the inner floor.

[100] 2. The seismic energy dissipated in the rift over the 23 -year-long period of study $\left(1.77 \times 10^{14} \mathrm{~N} \mathrm{~m}\right)$ does not account for the large deformation measured during that period, especially the $\sim 50 \mathrm{~cm}$ of horizontal extension across the inner floor. This demonstrates that the postrifting opening of the rift was essentially an aseismic process.

[101] 3. The largest part of the seismicity occurs below the Fieale-Shark Bay caldera zone and highlights the activity of this main volcanic system. Very little seismicity can be confidently attributed to slip on tectonic faults. This shows that most major faults in the rift either have not slipped over the period of study, or have slipped aseismically.

[102] 4. The seismicity in the Fieale-Shark Bay volcanic zone occurs in successive crises that produce microevents concentrated at the basis of the faults, tectonic and volcanic, that enclose the central hot rock pipe at depth. This makes events clustering in a volume capping the hot rock pipe. We interpret the events as produced by up and down vertical motions along the faults, especially along the eastern Fieale ring fault. The piston-like motions are likely related to inflation-deflation motions in the underlying magma reservoir and hot rock pipe.

[103] 5. The temporal evolution of the seismic activity reveals the postrifting behavior of the rift. The changes of localization and magnitude of the events are coeval with the change of deformation rates, particularly around 1986. These variations are interpreted as variations of magmatic dilatation rate within the inner floor, and they thus suggest the important role of the magmatic reservoir on the localization and magnitude of the extensive and vertical deformation in the rift. The first postrifting period (1979-1986) is characterized by a large number of events with magnitudes higher than during the following periods, but events still unable to account for the $35 \mathrm{~cm}$ of measured horizontal extension across the inner floor. These events result from the contraction produced by the ongoing opening and inflation of dikes below the inner floor. The second postrifting period (1987-2001) starts with a sudden decrease of the horizontal opening rate. That rate remains higher than the far field plate rate, however, which shows that the rift opening is still dominated by an active magmatic process. The activity of the volcanic system is indeed revealed by the seismicity. That seismicity occurs in successive crises in the Fieale-SB volcanic system that result from piston-like motions above the Fieale-SB reservoir.

[104] 6. From these observations, we describe the completion of a rifting cycle in Asal-Ghoubbet as follows. The 1978 rifting episode was an "active", magmatically driven and accommodated rifting process, with magmatic dikes actively opening in the rift inner floor as a result of an increased magma pressure in the Fieale-Shark Bay reservoir. That magmatic rifting episode reduced the stress regime in the rift to isotropic or even deviatoric compression. The magma pressure remained high in the following $7-8$ years, so that the dikes continued to open essentially aseismically. The stress regime in the rift remained between isotropic and compressional. The magma pressure abruptly dropped down at the end of 1986. That depletion induced high tensile stresses in the crust overlaying the Fieale-SB reservoir. Rifting could thus resume as a "passive", platedriven process. It occurred as an alternation of short phases of aseismic stress/strain relaxation in the crust due above the weak Fieale-SB hot rock pipe (stretching inducing pressure decrease), and short phases of seismic stress rebuild-up at the same place (magmatic pressure rebuilding above the Fieale-SB reservoir). A balance between the far-field plate motion and the response of the Fieale-SB magmatic system therefore seems to have controlled the 1987-2001 postrifting period. Thus, while since 1987 the rifting process has been passive and tectonically driven (i.e., driven by the 
tectonic plate motion), it is still preferentially accommodated in the magmatic Fieale-SB zone.

[105] Together these show that 23 years after its rifting episode, the AG segment still undergoes postrifting, transient deformation. Although variable in time, these transient processes have all been governed by the Fieale-SB magmatic system. Thus, since 1978, rare may be the faults or structures other than those close to Fieale that have significantly slipped or deformed, even aseismically. Hence, at present time, most rift faults may be essentially relaxed and locked, while the stress field in the rift may be still roughly isotropic, at least nearby Fieale-SB. That situation is expected to maintain as long as the Fieale-SB reservoir contains any "fresh magma" capable of moving up and down. Once magma supply is over, deviatoric stresses imposed by ongoing plate drift may resume accumulating on the tectonic rift faults. It is thus likely that "passive, tectonic" rifting events may next occur in the rift, for the faults to relax their stresses.

[106] Our study reveals that transient deformation can occur over long periods of time at plate boundaries, and results in large amounts of strain being relaxed. These transient episodes may be such that the plate boundary appears as in a steady state. In AG, the transient postrifting deformation is governed by the existence, nature and activity of a central magmatic plumbing system. More, this system controls the whole rifting process. Significant pressure increase in the plumbing system may trigger large rifting events that cause the rift to open at fast rates for several years. Pressure decrease in the plumbing system causes that opening to remain focused in the rift inner floor. It results that the rift eventually opens in a balanced, selfsustaining fashion. The opening remains focused at the rift axis and occurs essentially aseismically. That balance comes to a term only when the magma budget becomes too low for lava to continue rising up to the surface or the subsurface. Only in that case tectonic faults outside the inner floor may be "solicited" to contribute to the rifting process. Thus, though it is the process most shaping the landscape hence clearest to observation, the tectonic stretching has a little role in the rifting process. That role may change over long periods of time, however. In AG, the magma budget has decreased in the last $900 \mathrm{ka}$ to be lowest at present. That decrease may have caused the rifting process to evolve in time, from being mainly magmatic over the most part of the rift evolution, to becoming more tectonic in the present time. This may be why the rift faults form impressive escarpments in the present landscape. Tectonic rifting episodes producing large earthquakes may thus become more frequent in the future. More broadly the entire Afar region is dissected by a dense network of active normal faults that exhibit huge escarpments at the surface, some as high as a kilometer. This may suggest that the magma supply in Afar is presently quite low, requesting normal faults to develop and slip to accommodate the extensional stresses and strain imposed by the ongoing plate drift.

[107] We suggest that our description of the 23-year-long postrifting evolution of the AG Rift brings important elements to better prepare the postrifting survey of similar volcano-tectonic rifts, such as the Ethiopian Dabbahu segment that sustained a massive rifting event a year ago [Wright et al., 2006].
[108] Acknowledgments. We pay homage to Jean-Louis Cheminée, who worked a long time in the Asal-Ghoubbet Rift. As the director of the Volcanological IPGP Observatories, he encouraged this work and enabled us to have access to the seismological data. C. Jaupart and V. Courtillot are also thanked for their precious help in accessing the data. We are grateful to the Arta Observatory Staff and to the CERD researchers for their constant, precious scientific and logistic help. The French Army based at Djibouti allowed us working in the best conditions and is deeply thanked for its help. We thank S. Prejean, S. Haines, and B. Ildefonse for their fruitful reviews and comments that helped improve the manuscript. We also thank J-C. Ruegg, J.-B. De Chabalier, E. Jacques, C. Vigny, G. King, and L. Geoffroy for fruitful discussions. This work has been funded by the French CNRS Contribution 395 of INSU-France and 2210 of IPG-Paris.

\section{References}

Abdallah, A. (1997), Champ géothermique d'Asal, République de Djibouti, thèse de Doctorat, 137 pp., Univ. Denis Diderot, Paris.

Abdallah, A., V. Courtillot, M. Kasser, A. Y. Le Dain, J.-C. Lépine, B. Robineau, J.-C. Ruegg, P. Tapponnier, and A. Tarantola (1979), Afar seismicity and volcanism: Relevance to the mechanics of accreting plate boundaries, Nature, 282, 17-23.

Allard, P., H. Tazieff, and D. Dajlevic (1979), Observations of sea-floor spreading in Afar during the November 1978 fissure eruption, Nature, $279,30-33$.

Allen, R. M., et al. (2002), Plume-driven plumbing and crustal formation in Iceland, J. Geophys. Res., 107(B8), 2163, doi:10.1029/2001JB000584.

Arnott, S. K., and G. R. Foulger (1994a), The Krafla spreading segment, Iceland: 1 . Three-dimensional crustal structure and the spatial and temporal distribution of local earthquakes, J. Geophys. Res., 99, 23,801-23,825.

Arnott, S. K., and G. R. Foulger (1994b), The Krafla spreading segment, Iceland: 2. The accretionary stress cycle and nonshear earthquake focal mechanisms, J. Geophys. Res., 99, 23,827-23,842.

Audin, J., P. J. Vellutini, C. Coulon, P. Piguet, and J. Vincent (1990), The 1928-1929 eruption of Kammourta volcano-Evidence of tectonomagmatic activity in the Manda-Inakir rift and comparison with the Asal Rift, Afar depression, Republic of Djibuti, Bull. Volcanol., 52, $551-561$.

Audin, L., I. Manighetti, P. Tapponnier, F. Métivier, E. Jacques, and P. Huchon (2001), Fault propagation and climatic control of sedimentation on the Ghoubbet Rift Floor: Insights from the Tadjouraden cruise in the western Gulf of Aden, Geophys. J. Int., 144, 391-413.

Ballu, V., M. Diament, P. Briole, and J.-C. Ruegg (2003), 1985-1999 gravity field variations across the Asal Rift: Insights on vertical movements and mass transfer, Earth Planet. Sci. Lett., 208, 41-49.

Barclay, A. H., D. R. Toomey, and S. C. Solomon (2001), Microearthquake characteristics and crustal VP/VS structure at the Mid-Atlantic Ridge, $35^{\circ} \mathrm{N}$, J. Geophys. Res., 106, 2017-2034.

Beavan, J., P. Tregoning, M. Bevis, T. Kato, and C. Meertens (2002), Motion and rigidity of the Pacific Plate and implications for plate boundary deformation, J. Geophys. Res., 107(B10), 2261, doi:10.1029/ 2001JB000282.

Bergman, E. A., and S. C. Solomon (1990), Earthquake swarms on the Mid-Atlantic Ridge: Products of magmatism or extensional tectonics?, J. Geophys. Res., 95, 4943-4965.

Bizouard, H., R. Clocchiatti, and G. Marinellie (1980), Les tholéites à olivines à mégacristaux de bytonites du rift d'Asal (République de Djibouti): Quelques suggestions pour un modèle génétique, Bull. Soc. Geol. Fr. 7, 845-850.

Björnsson, A. (1985), Dynamics of crustal rifting in NE Iceland, J. Geophys. Res., 90, 10,151-10,162.

Brandsdottir, B., and P. Einarsson (1979), Seismic activity associated with the September 1977 deflation of the Krafla central volcano in northeastern Iceland, J. Volcanol. Geotherm. Res., 6, 197-212.

Callot, J.-P., L. Geoffroy, C. Aubourg, J. P. Pozzi, and D. Mège (2001), Magma flow in shallow dykes from the E-Greenland margin inferred from magnetic fabric studies, Tectonophysics, 334, 313-329.

Cann, J. R. (1974), A model for oceanic crustal structure developed, Geophys. J. R. Astron. Soc., 39, 169-187.

Cannat, M. (1996), How thick is the magmatic crust at slow spreading oceanic ridges?, J. Geophys. Res., 101, 2847-2857.

Cattin, R., C. Doubre, J.-B. De Chabalier, G. King, C. Vigny, J.-P. Avouac, and J.-C. Ruegg (2005), Thermo-mechanical modelling of quaternary deformation and post-seismic displacement in the Asal-Ghoubbet (Djibouti, Afar), Earth Planet. Sci. Lett., 239, 352-367.

Courtillot, V. (1982), Propagating rift and continental break-up, Tectonics, $1,239-250$

Courtillot, V., R. Armijo, and P. Tapponnier (1987), Kinematics of the Sinaluml; Triple Junction and a two-phase model of Arabia-Africa rifting, in Continental Extensional Tectonics, edited by M. P. Coward, J. F. Dewey, and P. L. Hancock, Geol. Soc. Spec. Publ., 28, 559-573. 
Courtillot, V., C. Jaupart, I. Manighetti, P. Tapponnier, and J. Besse (1999), On causal links between flood basalts and continental breakup, Earth Planet. Sci. Lett., 166, 177-195.

Cowie, P. A., C. H. Scholz, M. Edwards, and A. Malinverno (1993), Fault strain and seismic coupling on mid-ocean ridges, J. Geophys. Res., 98, $17,911-17,920$

Crane, K., L. Johnson, B. Appelgate, C. Nishinura, R. Buck, C. Jones, P. Vogt, and R. Kos'yan (1997), Volcanic and seismic swarm events on the Reykjanes ridge and their similarities to events on Iceland: Results of a rapid response mission, Mar. Geophys. Res., 19, 319338.

Dawson, P., B. Chouet, P. Okubo, A. Villaseñior, and H. Benz (1999), Three-dimensional velocity structure of the Kilauea caldera, Hawaii, Geophys. Res. Lett., 26, 2805-2808.

De Chabalier, J.-B., and J.-P. Avouac (1994), Kinematics of the Asal Rift (Dibouti) determined from the deformation of Fieale Volcano, Science, $265,1677-1681$.

Demange, J., L. Stieltjes, and J. Varet (1980), L'éruption d'Asal de Novembre 1978, Bull. Soc. Geol. Fr., 7, 837-843.

DeMets, C., R. G. Gordon, D. F. Argus, and S. Stein (1990), Current plate motions, Geophys. J. Int., 101, 425-478.

De Natale, G., A. Zollo, A. Ferraro, and J. Virieux (1995), Accurate fault mechanism determinations for a 1984 earthquake swarm at Campi Flegre caldera (Italy) during an unrest episode: Implications for volcanological research, J. Geophys. Res., 100, 24,167-24,185.

Detrick, R. S., J. C. Mutter, P. Buhl, and I. I. Kim (1990), No evidence for multichannel reflection data for a crustal magma chamber in the MARK area on the Mid-Atlantic Ridge, Nature, 347, 61-64

Detrick, R. S., H. D. Needham, and V. Renard (1995), Gravity anomalies and crustal thickness variations along the Mid-Atlantic Ridge between $33^{\circ} \mathrm{N}$ and $40^{\circ} \mathrm{N}$, J. Geophys. Res., 100, 3767-3787.

Doubre, C., and L. Geoffroy (2003), Rift-zone development around a plume-related magma centre on the Isle of Skye (Scotland): A model for stress inversions, Terra Nova, 15, 230-237.

Doubre, C., and G. Peltzer (2007), Fluid-controlled faulting process in the Asal rift, Djibouti, from $8 \mathrm{yr}$ of radar interferometry observations, Geology, 35(1), 69-72, doi:10.1130/G23022A.1.

Doubre, C., I. Manighetti, C. Dorbath, L. Dorbath, E. Jacques, and J.-C. Delmond (2007), Crustal structure and magmato-tectonic processes in an active rift (Asal-Ghoubbet, Afar, East Africa): 1. Insights from a 5-month seismological experiment, J. Geophys. Res., doi:10.1029/2005JB003940, in press.

Dunn, R. A., V. Lekiæ, R. S. Detrick, and D. R. Toomey (2005), Threedimensional seismic structure of the Mid-Atlantic Ridge (35(N): Evidence for focused melt supply and lower crustal dike injection, J. Geophys. Res. 110, B09101, doi:10.1029/2004JB003473.

Dziak, R. P., and C. G. Fox (1999), The January 1998 earthquake swarm at Axial Volcano, Juan de Fuca Ridge: Hydroacoustic evidence of seafloor volcanic activity, Geophys. Res. Lett., 26, 3429-3432.

Ebinger, C. J., and N. J. Hayward (1996), Soft plates and hot spots: Views from Afar, J. Geophys. Res., 101, 21,859-21,876

Einarsson, P., and B. Brandsdottir (1980), Seismological evidence for lateral intrusion during the July 1978 deflation of the Krafla volcano in NE Iceland, J. Geophys., 47, 160-165.

Embley, R. W., W. W. Chadwick, M. R. Perfit, M. C. Smith, and J. R. Delaney (2000), Recent eruptions on the CoAxial segment of the Juan de Fuca Ridge: Implications for mid-ocean ridge accretion processes, J. Geophys. Res., 105, 16,501-16,525.

Evans, J. R., D. Eberhart-Phillips, and C. H. Thurber (1994), User's manua for simulps 12 for imaging $V p$ and $V p / V_{s}$ : A derivative of the "Thurber" tomographic inversion simul3 for local earthquakes and explosions, U.S Geol. Surv. Open File, 94-431.

Feuillet, N., C. Nostro, C. Chiarabba, and M. Cocco (2004), Coupling between earthquake swarms and volcanic unrest at the Alban Hills Volcano (central Italy) modeled through elastic stress transfer, J. Geophys. Res., 109, B02308, doi:10.1029/2003JB002419.

Feuillet, N., M. Cocco, C. Musumeci, and C. Nostro (2006), Stress interaction between seismic and volcanic activity at Mt Etna, Geophys. J. Int., $164,697-718$.

Garel, E., O. Dauteuil, and Y. Lagabrielle (2002), Deformation processes at fast to ultra-fast oceanic spreading axes: Mechanical approach, Tectonophysics, 346, 223-246.

Gouin, P. (1979), Earthquake History of Ethiopia and the Horn of Africa, 259 pp., Int. Dev. Res. Centre, Ottawa, Ont., Canada.

Gudmundsson, A. (1986), Mechanical aspects of postglacial volcanism and tectonics of the Reykjanes Peninsula, southwest Iceland, J. Geophys. Res., 91, 12,771-12,721.

Gudmundsson, A. (1998), Magma chambers modeled as cavities explain the formation of rift zone central volcanoes and their eruption and intrusion statistics, J. Geophys. Res., 103, 7401-7412.
Gudmundsson, A., and I. F. Loetveit (2005), Dyke emplacement in a layered and faulted rift zone, J. Volcanol. Geotherm. Res., 144, $311-$ 327.

Gudmundsson, O., B. Brandsdottir, W. Menke, and G. E. Sigvaldason (1994), The crustal magma chamber of the Katla volcano in south Iceland revealed by 2-D seismic undershooting, Geophys. J. Int., 119, 277-296. Gutenberg, R., and C. F. Richter (1944), Frequency of earthquakes in California, Bull. Seismol. Soc. Am., 34, 185-188.

Hayward, N. J., and C. J. Ebinger (1996), Variations in the long-axis segmentation of the Afar rift system, Tectonics, 15, 244-257.

Heki, K., G. R. Foulger, B. R. Julian, and C. H. Jahn (1993), Plate dynamics near divergent plate boundaries: Geophysical implications of postrifting crustal deformation in NE Iceland, J. Geophys. Res., 98 $14,279-14,297$

Helgason, J., and M. Zentilli (1985), Field characteristics of laterally emplaced dikes: Anatomy of an exhumed miocene dike swarm in Reydarfjödur, eastern Iceland, Tectonophysics, 115, 247-274.

Herrero-Bervera, E., G. P. L. Walker, E. Cañion-Tapia, and M. O. Garcia (2001), Magnetic fabric and inferred flow direction of dikes, cone-sheets and sill swarms, Isle of Skye, Scotland, J. Volcanol. Geotherm. Res., 106, $195-210$

Hess, P. (1992), Phase equilibria constraints on the origin of ocean floor basalts, in Mantle Flow and Melt Generation at Mid-Ocean Ridges, Geophys. Monogr. Ser., vol. 71, edited by J. Phipps Morgan, D. Blackman, and J. Sinton, p. 67, AGU, Washington, D. C

Hirose, H., K. Hirahara, F. Kimata, N. Fujii, and S. Miyazaki (1999), A slow thrust slip event following the two 1996 Hyuganada earthquakes beneath the Bungo Channel, southwest Japan, Geophys. Res. Lett., 26, $3237-3240$

Hofton, M. A., and G. R. Foulger (1996a), Postrifting anelastic deformation around the spreading plate boundary, north Iceland: 1. Modeling of the 1987-1992 deformation field using a viscoelastic Earth structure, J. Geophys. Res., 101, 25,403-25,421.

Hofton, M. A., and G. R. Foulger (1996b), Postrifting anelastic deformation around the spreading plate boundary, north Iceland: 2 . Implications of the model derived from the 1987-1992 deformation field, J. Geophys. Res. $101,25,423-25,436$

Hu, Y., K. Wang, J. He, J. Klotz, and G. Khazaradze (2004), Threedimensional viscoelastic finite element model for postseismic deformation of the great 1960 Chile earthquake, J. Geophys. Res., 109, B12403, doi:10.1029/2004JB003163.

Jacques, E. (1995), Fonctionnement sismique et couplage lastique des failles en Afar, thesis, 485 pp., Univ. Paris 7-IPGP, Paris, Dec.

Jahn, C. H., G. Seeber, G. R. Foulger, and P. Einarsson (1994), GPS epoch measurements spanning the Mid-Atlantic plate boundary in northern Iceland 1987-1990, in Gravimetry and Space Techniques Applied to Geodynamics and Ocean Dynamics, Geophys. Monogr. Ser., vol. 82, edited by B. E. Schultz et al., pp. 109-123, AGU, Washington, D. C.

Joron, J.-L., M. Treuil, H. Jaffrezic, and B. Villemant (1980), Etude géochimique des elements en traces dans les series de roches volcaniques du rift d'Asal: Identification et analyse des processus d'accrétion, Bull. Soc. Geol. Fr. 7, 851-861.

Kanamori, H., and D. L. Anderson (1975), Theoretical basis of some empirical relations in seismology, Bull. Seismol. Soc. Am., 65, 1073-1095

Karson, J. A., et al. (1987), Along-Axis variations in seafloor spreading in the MARK area, Nature, 328, 681-685.

Kasser, M., J.-C. Ruegg, and J.-C. Lépine (1987), Geodetic measurements on the Asal Rift (Djibouti): Twelve years of observations, J. Geodyn., 7 , $221-226$.

Klein, F. W. (1978), Hypocenter location program HYPOINVERSE, Part 1, Users guide to versions 1, 2, 3 and 4, U.S. Geol. Surv. Open File, $78-$ 694.

Knight, M. D., and G. P. L. Walker (1988), Magma flow in dikes of the Koolau complex, Oahu, determined from magnetic fabric studies, J. Geophys. Res., 93, 4301-4319.

Kreemer, C., W. E. Holt, and A. J. Haines (2003), An integrated global model of present-day plate motions and plate boundary deformation, Geophys. J. Int., 154, 8-34.

Le Dain, A-.Y., B. Robineau, and P. Tapponnier (1979), Les effets tectoniques de l'événement sismique et magmatique de Novembre 1978 dans le rift d'Asal-Ghoubbet, Bull. Soc. Geol. Fr., 7, 817-822.

Lee, W. H. K., and J. C. Lahr (1975), HYP071 (Revised): A computer program for determining hypocenter, magnitude, and first motion pattern of local earthquakes, U. S. Geol. Surv. Open File Rep., 75-311, 113 pp.

Lépine, J.-C., and A. Hirn (1992), Seismotectonics in the Republic of Djibouti linking the Afar Depression and the Gulf of Aden, Tectonophysics, 209, 65-86.

Lépine, J.-C., J.-C. Ruegg, and L. Steinmetz (1972), Seismic profiles in the Djibouti area, Tectonophysics, 15, 59-64. 
Lépine, J.-C., J.-C. Ruegg, and A. M. Anis (1980), Sismicité du rift d'AsalGhoubbet pendant la crise sismo-volcanique de Novembre 1978, Bull. Soc. Geol. Fr. 7, 809-816.

Lin, J., G. M. Purdy, H. Schouten, J.-C. Sempere, and C. Zervas (1990), Evidence from gravity data for focused magmatic accretion along the Mid-Atlantic Ridge, Nature, 334, 627-632.

Linde, A. T., M. T. Gladwin, M. J. S. Johnston, R. L. Gwyther, and R. G. Bilham (1996), A slow earthquake sequence on the San Andreas fault, Nature, 383, 65-68.

Lowry, A. R., K. M. Larson, V. Kostoglodov, and R. Bilham (2001), Transient fault slip in Guerrero, southern Mexico, Geophys. Res. Lett., 28 , $3753-3756$.

Makris, J., and A. Ginzburg (1987), The Afar Depression: Transition between continental rifting and sea-floor spreading, Tectonophysics, $141,199-214$.

Manighetti, I. (1993), Dynamique des systèmes extensifs en Afar, thèse de Doctorat, 240 pp., Univ. Pierre Marie Curie, Paris.

Manighetti, I., P. Tapponnier, V. Courtillot, S. Gruszow, and P.-Y. Gillot (1997), Propagation of rifting along the Arabia-Somalia plate boundary: The gulfs of Aden and Tadjoura, J. Geophys. Res., 102, 2681-2710.

Manighetti, I., P. Tapponnier, Y. P-Gillot, E. Jacques, V. Courtillot, R. Armijo, J.-C. Ruegg, and G. King (1998), Propagation of rifting along the ArabiaSomalia plate boundary: Into Afar, J. Geophys. Res., 103, 4947-4974.

Manighetti, I., P. Tapponnier, V. Courtillot, Y. Gallet, E. Jacques, and Y. Gillo (2001a), Strain transfer between disconnected, propagating rifts in Afar, J. Geophys. Res., 106, 13,613-13,665.

Manighetti, I., G. C. P. King, Y. Gaudemer, C. H. Scholz, and C. Doubre (2001b), Slip accumulation and lateral propagation of active normal faults in Afar, J. Geophys. Res., 106, 13,667-13,696.

Manighetti, I., G. King, and C. Sammis (2004), The role of the off-fault damage in the evolution of normal faults, Earth Planet. Sci. Lett., 217, $399-408$

Marone, C. (1998), Laboratory-derived friction laws and their application to seismic faulting, Annu. Rev. Earth Planet. Sci., 26, 643-696.

McClusky, S., S. Balassanian, A. Barka, and C. Demir (2000), Global Positioning System constraints on plate kinematics and dynamics in the eastern Mediterranean and Caucasus, J. Geophys. Res., 105, 56955719

McGregor, L. M., S. Constable, and M. C. Sinha (1998), The RAMESSES experiment-III. Controlled-source electromagnetic sounding of the Reykjanes Ridge at $57^{\circ} 45^{\prime} \mathrm{N}$, Geophys. J. Int., 135, 773-789.

Meissner, R., and J. Strehlau (1982), Limits of stresses in continental crusts and their relation to the depth-frequency distribution of shallow earthquakes, Tectonics, 1, 73-79.

Melbourne, T. I., F. H. Webb, J. M. Stock, and C. Reigber (2002), Rapid postseismic transients in subduction zones from continuous GPS, J. Geophys. Res., 107(B10), 2241, doi:10.1029/2001JB000555.

Miller, D. S., and R. B. Smith (1999), $P$ and $S$ velocity structure of the Yellowstone volcanic field from local earthquake and controlled-source tomography, J. Geophys. Res., 104, 15,105-15,121.

Miller, M., T. Melbourne, D. J. Johnson, and W. Summer (2002), Periodic slow earthquakes from the Cascadia subduction zone, Science, 295(5564), p.2423.

Mlynarski, M., and J. Zlotnicki (2001), Fluid circulation in the active emerged Asal Rift (east Africa, Djibouti) inferred from self-potential and Telluric-Telluric prospecting, Tectonophysics, 339, 455-472.

Moreira, M., L. Geoffroy, and J-.P. Pozzi (1999), Ecoulement magmatique dans les dykes du point chaud des Açores: Etude préliminaire par anisotropie de susceptibilité magnétique (ASM) dans l'1circ;le de San Jorge, C. R. Acad., $329,15-22$.

Muller, C., and W. Jokat (2000), Seismic evidence for volcanic activity discovered in central Arctic, Eos Trans. $A G U, 81,265$.

Muller, J. R., G. Ito, and S. J. Martell (2001), Effects of volcano loading on dike propagation in an elastic half-space, J. Geophys. Res., 106, 11,10111,114 .

Navin, D. A., C. Pierce, and M. C. Sinha (1998), The RAMASSES experiement-II. Evidence for accumulated melt beneath a slow spreading ridge from wide-angle refraction and multichannel reflection seismic profiles, Geophys. J. Int., 135, 746-772.

Nisbet, E. G., and C. M. R. Fowler (1978), The Mid-Atlantic Ridge at $37^{\circ}$ and $45^{\circ} \mathrm{N}$ : some geophysical and petrological constraints, Geophys. J. R. Astron. Soc., 54, 631-660.

Okal, E. A., and L. M. Stewart (1982), Slow earthquakes along oceanic fracture zones: Evidence for aesthenospheric flow away from hotspots? Earth Planet. Sci. Lett., 57, 75-87.

Okubo, P., and J. S. Nakata (2003), Tectonic pulses during Kilauea's current long-term eruption, in The $P u$ " $u$ "O "o-Kupaianaha Eruption of Kilauea Volcano, Hawai" $i$; the First 20 Years, edited by C. Heliker, D. A. Swanson, and T. J. Takahashi, U.S. Geol. Surv. Prof. Pap., 1676, $173-$ 186.
Parson, L. M., et al. (1993), En echelon axial volcanic ridges at the Reykjanes Ridge: A life cycle of volcanism and tectonics, Earth Planet. Sci. Lett., 117, 73-87.

Parson, L., E. Gracia, D. Coller, C. German, and D. Needham (2000), Second-order segmentation; the relationship between volcanism and tectonics at the MAR, $38^{\circ} \mathrm{N}-35^{\circ} 40^{\prime} \mathrm{N}$, Earth Planet. Sci. Lett., 178, $231-$ 251.

Pechmann, J. C., J. C. Bernier, S. J. Nava, F. M. Terra, and W. Arabasz (2001), Correction of systematic time-dependant coda magnitude errors in the Utah and Yellowstone National Park region earthquake catalog, 1981-2001, Eos Trans. AGU, 82(47), Fall Meet. Suppl., Abstract S11B0572.

Peirce, C., A. Gardiner, and M. Sinha (2005), Temporal and spatial cyclicity of accretion at slow-spreading ridges-Evidence from the Reykjanes Ridge, Geophys. J. Int., 163, 56-78.

Pinel, V., and C. Jaupart (2000), The effect of edifice load on magma ascent beneath a volcano, Philos. Trans. R. Soc. London, Ser. A, 358, $1515-$ 1532.

Pinzuti, P., I. Manighetti, E. Humler, and J. Carlut (2001), Magmato-tectonic evolution of Asal Rift, Afar depression, Eos Trans. AGU, 82(47), Fall Meet. Suppl., Abstract T51E-03.

Pollard, D. D., P. T. Delaney, W. A. Duffield, E. T. Endo, and A. T. Okamura (1983), Surface deformation in volcanic rift zones, Tectonophysics, 94, 541-584.

Pollitz, F. F., G. Peltzer, and R. Bürgmann (2000), Mobility of continental mantle: Evidence from postseismic geodetic observation following the 1992 Landers earthquake, J. Geophys. Res., 105, 8035-8054.

Rubin, A. M. (1990), A comparison of rift-zone tectonics in Iceland and Hawaii, Bull. Volcanol., 52, 302-319.

Rubin, A. M. (1992), Dike-induced faulting and graben subsidence in volcanic rift zones, J. Geophys. Res., 97, 1839-1858.

Rubin, A. M., and D. Gillard (1998), Dike-induced earthquakes: Theoretical considerations, J. Geophys. Res., 103, 10,017-10,030.

Rubin, A. M., and D. D. Pollard (1988), Dike-induced faulting on rift zones of Iceland and Afar, Geology, 16, 413-417.

Ruegg, J.-C. (1975), Structure profonde de la croûte et du manteau supérieur du Sud-Est de l'Afar d'après les données sismiques, Ann. Geophys., $31,329-360$

Ruegg, J.-C., and M. Kasser (1987), Deformation across the Asal-Ghoubbet Rift, Djibouti, uplift and crustal extension, Geophys. Res. Lett., 14, $745-$ 748

Ruegg, J.-C., J.-C. Lépine, and A. Tarantola (1979), Geodetic measurements of rifting associated with a seismo-volcanic crisis in Afar, Geophys. Res. Lett., 6, 817-820.

Ruegg, J.-C., M. Kasser, and J.-C. Lépine (1987), Strain accumulation across the Asal-Ghoubbet Rift, Djibouti, East Africa, J. Geophys. Res., 89, 6237-6246.

Ruegg, J-.C., F. Gasse, and P. Briole (1990), Mouvements du sol holocènes dans le rift d'Asal à Djibouti, C. R. Acad. Sci., 310, 1687-1694.

Saemundsson, K. (1978), Fissure swarms and central volcanoes of the neovolcanic zones of Iceland, Geol. J., Spec. Issue., 10, 415-432.

Saemundsson, K. (1979), Outline of the geology of Iceland, Jökull, 29, $7-28$.

Savage, J. C., R. W. Simpson, and M. H. Murray (1998), Strain accumulation rates in the San Francisco Bay area, 1972-1989, J. Geophys. Res. 103, 18,039-18,051

Scholz, C. H. (1988), The brittle-plastic transition and the depth of seismic faulting, Geol. Rundsch.u, 77, 313-328.

Scholz, C. H. (2002), The Mechanics of Earthquakes and Faulting, 2nd ed., 471 pp., Cambridge Univ. Press, New York.

Segall, P., P. Cervelli, S. Owen, M. Lisowski, and A. Miklius (2001), Constraints on dike propagation from continuous GPS measurements, J. Geophys. Res., 106, 19,301-19,318.

Sengor, A. M. C., and K. Burke (1979), Mid-Mesozoic closure of PermoTriassic Tethys and its implications, Nature, 279, 590-593.

Sibson, R. H. (1982), Fault zone models, heat flow, and the depth distribution of earthquakes in the continental crust of the United States, Bull. Seismol. Soc. Am., 68, 1421-1448.

Sibson, R. H. (1984), Roughness at the base of the seismogenic zone: Contributing factors, J. Geophys. Res., 89, 5791-5799.

Sigmundsson, F., H. Vadon, and M. D. Massonnet (1997), Readjustment of the Krafla spreading segment to crustal rifting measured by satellite radar interferometry, Geophys. Res. Lett., 24, 1843-1846.

Sinha, M. C., S. C. Constable, C. Peirce, A. White, G. Heinson, L. M MacGregor, and D. A. Navin (1998), Magmatic processes at slow spreading ridges: Implications of the RAMASSES experiment at $57^{\circ} 45^{\prime} \mathrm{N}$ on the Mid-Atlantic Ridge, Geophys. J. Int., 135, 731-745.

Sinton, J. M., and R. S. Detrick (1992), Mid-ocean ridge magma chambers, J. Geophys. Res., 97, 197-216. 
Smith, D. K., and J. R. Cann (1992), The role of seamount volcanism in crustal construction at the Mid-Atlantic Ridge $\left(24^{\circ}-30^{\circ} \mathrm{N}\right)$, J. Geophys Res., 97, 1645-1658.

Sohn, R. A., D. J. Fornari, K. L. Von Damm, J. A. Hildebrand, and S. C. Webb (1998), Seismic and hydrothermal evidence for a cracking event on the East Pacific Rise crest at $9^{\circ} 50^{\prime} \mathrm{N}$, Nature, 396, 159-161.

Speight, J. M., R. R. Skelhorn, T. Sloan, and R. J. Knapp (1982), The dyke swarms of Scotland, in Igneous Rocks of British Isles, edited by D. S. Sutherland, pp. 449-459, Springer, New York.

Stein, R., P. Briole, J.-C. Ruegg, P. Tapponnier, and F. Gasse (1991), Contemporary, Holocene, and Quaternary deformation of the Asal Rift, Djibouti: Implications for the mechanics of slow spreading ridges, J. Geophys. Res., 96, 21,789-21,806.

Tapponnier, P., R. Armijo, I. Manighetti, and V. Courtillot (1990), Bookshelf faulting and horizontal block rotations between overlapping rift zones in southern Afar, Geophys. Res. Lett., 17, 1-4.

Tarantola, A., J.-C. Ruegg, and J.-C. Lépine (1979), Geodetic evidence for rifting in Afar: A brittle-elastic model of the behaviour of the lithosphere, Earth Planet. Sci. Lett., 45, 435-444.

Tarantola, A., J.-C. Ruegg, and J.-P. Lépine (1980), Geodetic evidence for rifting in Afar, 2. Vertical displacements, Earth Planet. Sci. Lett., 48 , $363-370$

Toda, S., R. S. Stein, and T. Sagiya (2002), Evidence from the AD 2000 Izu islands earthquake swarm that stressing rate governs seismicity, Nature, $419,58-61$.

Tolstoy, M., D. R. Bohnenstiehl, M. H. Edwards, and G. J. Kurras (2001), Seismic character of volcanic activity at the ultraslow-spreading Gakkel Ridge, Geology, 29, 1139-1142.

Troise, C., F. Pingue, and G. De Natale (2003), Coulomb stress changes at calderas: Modeling the seismicity of Campi Flegrei (southern Italy), J. Geophys. Res., 108(B6), 2292, doi:10.1029/2002JB002006.

Tse, S. T., and J. R. Rice (1986), Crustal earthquake instability in relation to the depth variation of frictional slip properties, J. Geophys. Res., 91, 9452-9472

Turcotte, D. L., and S. H. Emerman (1983), Mechanisms of active and passive rifting, Tectonophysics, 94, 39-50.

Van Ngoc, P., D. Boyer, J.-L. Le Mouël, and V. Courtillot (1981), Identification of a magma chamber in the Ghoubbet-Asal Rift (Djibouti) from a magnetotelluric experiment, Earth Planet. Sci. Lett., 52, 372-380.

Van Wyk de Vries, B., and O. Merle (1996), The effect of volcanic constructs on rift fault patterns, Geology, 24, 643-646.

Varet, J. (1978), Geology of central and southern Afar (Ethiopia and Djibouti Republic), map and 124 pp. report, Centre Natl. de la Rec. Sci., Paris.
Vigier, N., B. Bourdon, J.-L. Joron, and C. J. Allègre (1999), U-decay series and trace element systematics in the 1978 eruption of Ardoukôba, Asal Rift: Timescale of magma crystallization, Earth Planet. Sci. Lett., 174, $81-97$.

Vigny, C., P. Huchon, J.-C. Ruegg, K. Khanbari, and L. M. Asfaw (2006), Confirmation of Arabia plate slow motion by new GPS data in Yemen, J. Geophys. Res., 111, B02402, doi:10.1029/2004JB003229.

Vigny, C., J.-B. de Chabalier, J-.C. Ruegg, P. Huchon, K. L. Feigl, R. Cattin, L. Asfaw, and K. Kanbari (2007), Twenty-five years of geodetic measurements along the Tadjoura-Asal rift system, Djibouti, East Africa, J. Geophys. Res., doi:10.1029/2004JB003230, in press.

Walker, G. (1999), Volcanic rift zones and their intrusion swarms, J. Volcanol. Geotherm. Res., 94, 21-34.

Wolfe, C. J., G. M. Purdy, D. R. Toomey, and S. Solomon (1995), Microearthquake characteristics and crustal velocity structure at $29^{\circ} \mathrm{N}$ on the Mid-Atlantic Ridge: The architecture of a slow spreading segment, J. Geophys. Res., 100, 24,449-24,472.

Wright, T. J., C. Ebinger, J. Biggs, A. Ayele, G. Yirgu, D. Keir, and A. Stork (2006), Magma-maintained rift segmentation at continental rupture in the 2005 Afar dyking episode, Nature, 442, 291-294, doi:10.1038/ nature 04978 .

Zan, L., G. Gianelli, P. Passerini, C. Troisi, and A. O. Haga (1990), Geothermal exploration in the Republic of Djibouti: Thermal and geological data of the Hanle and Asal areas, Geothermics, 19, 58561

Zollo, A., W. Marzocchi, P. Capuano, A. Lomax, and G. Iannaccone (2002), Space and time behavior of seismic activity at Mt Vesuvius volcano, southern Italy, Bull. Seismol. Soc. Am., 95, 625-650.

D. Bertil, BRGM, Service Géologique Régional Guadeloupe, Guadeloupe, France.

C. Dorbath and L. Dorbath, EOST, 5, rue René Descartes, F-67084 Strasbourg, France.

J. C. Delmond, Volcanologic Observatories, IPGP, 4 Place Jussieu, F75252 Paris Cedex 05, France.

C. Doubre, Department of Earth and Space Sciences, Geology Building, 595 Charles E. Young Drive East, University of California Los Angeles, CA 90095-1567, USA.

I. Manighetti, Laboratoire de Géophysique Interne et Tectonophysique (LGIT), BP 53, F-38041 Grenoble Cedex 9, France. (isabelle.manighetti@ obs.ujf-grenoble.fr) 